Portland State University

PDXScholar

Spring 7-6-2018

\title{
Volcanic Glass as a Paleoenvironmental Proxy: Comparing Preparation Methods on Ashes from the Lee of the Cascade Range in Oregon, USA
}

Tessa Boe Carlson

Portland State University

Follow this and additional works at: https://pdxscholar.library.pdx.edu/open_access_etds

Part of the Geochemistry Commons, and the Volcanology Commons Let us know how access to this document benefits you.

Recommended Citation

Carlson, Tessa Boe, "Volcanic Glass as a Paleoenvironmental Proxy: Comparing Preparation Methods on Ashes from the Lee of the Cascade Range in Oregon, USA" (2018). Dissertations and Theses. Paper 4472. https://doi.org/10.15760/etd.6356

This Thesis is brought to you for free and open access. It has been accepted for inclusion in Dissertations and Theses by an authorized administrator of PDXScholar. Please contact us if we can make this document more accessible: pdxscholar@pdx.edu. 
Volcanic Glass as a Paleoenvironmental Proxy:

Comparing Preparation Methods on Ashes from the Lee of the Cascade Range in Oregon, USA

by

Tessa Boe Carlson

A thesis submitted in partial fulfillment of the requirements for the degree of

Master of Science

in Geology

Thesis Committee:

John Bershaw, Chair

Ashley Streig

Martin Streck

Portland State University

2018 


\begin{abstract}
Deuterium ratios $(\delta \mathrm{D})$ of hydrated volcanic glass have been used to reconstruct paleoenvironments, although the reliability and proper sample preparation protocol have been debated. In this study, hydrated volcanic ash samples from the lee of the Cascades were prepared using two separate methods. Method 1 involves sonicating and rinsing samples with hydrochloric acid ( $\mathrm{HCl})$ followed by hand-selection of glass shards $(125-212 \mu \mathrm{m})$. Method 2 requires hydrochloric acid ( $\mathrm{HCl}$ ) and hydrofluoric acid (HF) abrasion as well as heavy liquid separation of shards $(70-150 \mu \mathrm{m})$. Method 2 produced more consistent results with decreased intra-replicate variability in both water content (-0.92 wt. \%) and deuterium values $(-2.5 \%$ o $\delta$ ). Method $2 \delta \mathrm{D}$ values of $\geq 99 \%$ isotropic glass were also 2.5 - $10 \%$ more negative relative to Method 1 values, with an increasing discrepancy with age (3.68 - 32.66 Ma). Method 2 results suggest volcanic glass did not re-equilibrate with modern water, based on 1) $<2 \%$ discrepancies between samples of the same ash flow taken from unique sample localities and 2) a 20\%0 difference between samples of different ages ( $~ 8 \mathrm{Ma}$ apart) from the same locality. These results support the specified use of HF abrasion and heavy liquid separation on $70-150 \mu \mathrm{m}$ glass shards to minimize the impact of contaminants on reconstructed paleowater $\delta \mathrm{D}$ values.
\end{abstract}




\section{TABLE OF CONTENTS}

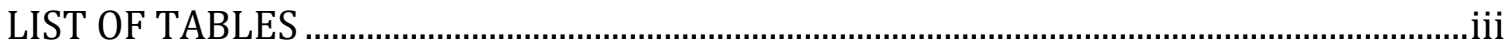

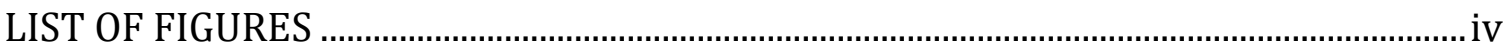

1 INTRODUCTION

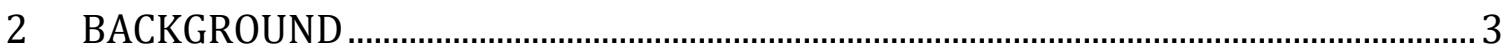

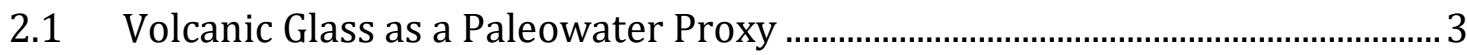

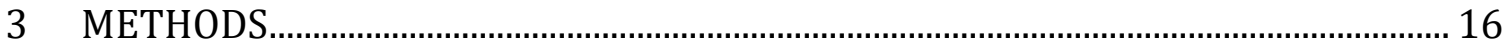

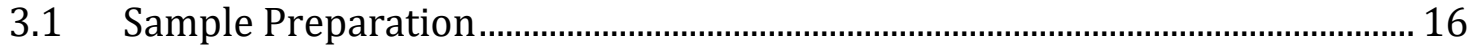

3.2 Isotope Analyses ............................................................................................. 21

3.3 Sample Selection Overview …………………………………………………..... 21

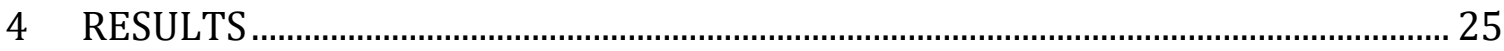

4.1 Comparison of Sample Preparation Methods ……………………………...... 25

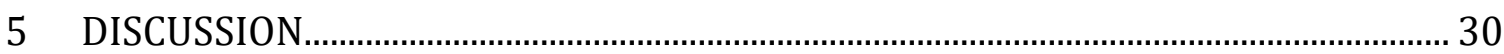

5.1 Isolating Paleowater Signals in Volcanic Glass ................................................ 30

5.2 Evidence of Paleoenvironmental Water in Volcanic Glass................................. 33

5.3 Recommendations for Sample Selection and Preparation.................................. 35

5.4 Paleoenvironmental Implications..................................................................... 36

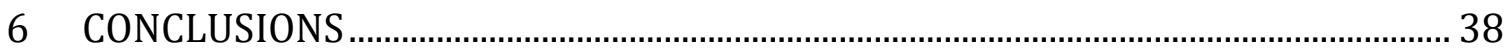

APPENDICES

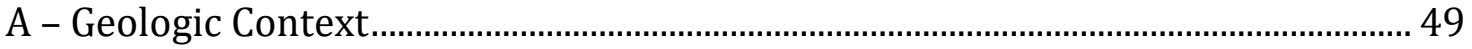

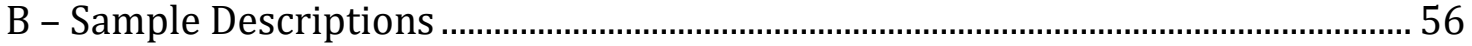

C - Preparation Methods .............................................................................................. 61

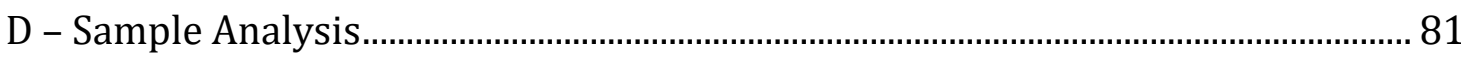

E - Additional Data Tables and Plots................................................................................... 83

F - Opportunities for Additional Research.................................................................... 97 


\section{LIST OF TABLES}

Table 3-1. Summary comparing preparation Method 1 and Method 2 ......................... 16

Table 3-2. Location, age, and source information for analyzed samples.

Prefixes indicate preparation Method 1 (M1) or Method 2 (M2)

(bold), while asterisks (*) indicate samples that have been

prepared using both methods. An overview of field interpretations

is also included. See Appendix B for more detail.

Table 4-1. Average $\delta \mathrm{D}(\%$, VSMOW) and wt. \% H2O of water extracted from replicates of each glass sample. Intra-replicate range is calculated from 2-6 replicates. Prefix M1/M2 signifies Method 1/Method 2, respectively, with Method 2 in bold. Samples with interpreted lacustrine hydration water are denoted with an asterisk $\left(^{*}\right)$ next to

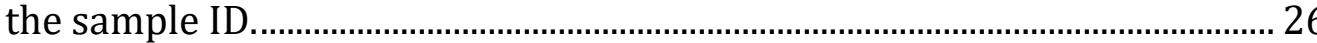




\section{LIST OF FIGURES}

Figure 1-1. Hillshade map of the Western United States with approximate area of this study outlined as a black rectangle. Locations of volcanic glass paleowater proxy studies are shown (Cassel et al., 2014, 2009; Smith et al., 2017; Mulch et al., 2008; Fan et al., 2014). There is a conspicuous lack of volcanic glass proxy data for the northwestern US. Although Mazama ash in Oregon has been studied by Seligman and others (2016), it is not included here because all samples are $<10 \mathrm{Ka}$.

Figure 2-1. Sketches of common glass shard morphologies ranging from bubble wall shards to pumice shards. Cuspate or lunate fragments of broken bubble walls that are ' $Y$ ' shaped in cross-section are typically a junction of three bubbles or two concave plates of adjoining bubbles. Flat plates are broken from the wall of a large, flattened vesicles. Pumiceous fragments may have round or elongate cavities. Figure and caption adapted from Fisher and Schmincke (1984). 5

Figure 2-2. Elevation profile of Oregon along a transect at $44^{\circ}$ latitude (gray line). Modern deuterium $(\delta \mathrm{D})$ values relative to standard mean ocean water (SMOW) in central to northern Oregon and southern Washington are plotted with their respective longitude, indicated by various shapes (Coplen and Kendall, 2000; Ingebrisen et al., 1988; Friedman, 2000; Friedman et al., 2002; IAEA, b)

Figure 2-3 Top: A schematic figure of the altered layer of volcanic glass, including the metal-ion depleted hydrous region in the glass interior that retains original covalent bonds, the microporous silica-rich layer near the exterior surface (gel or passivating layer), and the crystalline and amorphous reaction products precipitated at the surface of the glass. Bottom: Relative distribution of major elements through the altered layer. Figure and caption from Cassel and Breecker (2017) and references therein.

Figure 3-1. Comparative flow charts for Method 1 and Method 2. For Method 1 , selected samples did not show evidence of devitrification under a hand sample microscope, and birefringent minerals were removed under petrographic microscope. For Method 2, purity was checked via temporary immersion oil slides after each step. Preparation is ceased at $\geq 99 \%$ isotropic glass in Method 2 . See Appendix C, Figure C-3 for examples of sample separates at various stages of preparation

Figure 3-2. Examples of samples prepared using Method 1. A.) Sample M1CVG014. Raw sieved sample (top) and hand-picked, HCl treated, and sonicated shards (bottom). B.) Sample M1-CVG019. Raw 
sieved sample (top) and hand-picked, $\mathrm{HCl}$ treated, and sonicated shards (bottom).

Figure 3-3. Temporary immersion oil slides of 33Ma Tuff of Dale prepared with Method 2 (CVG013). The top left image is the raw sample, and the bottom right is $>99 \%$ pure glass (star). The top half of each photo is uncrossed polarized light, and bottom half is crossed polarized light with a full wave $(1 \lambda)$ retardation plate (blue)..

Figure 3-4. Elevation map of Oregon showing sample localities. Circles are samples prepared using Method 1 and triangles are Method 2. Numbers in parentheses are shortened sample identifiers, with bold font indicating preparation Method 2 .

Figure 4-1. Average wt. $\% \mathrm{H}_{2} \mathrm{O}$ versus Age (Ma) for all analyzed samples. Vertical error bars indicate intra-replicate range of wt $\% \mathrm{H}_{2} \mathrm{O}$ measurements. Age ranges are $2 \sigma$ uncertainty based on radiometric dates or relative date range based on stratigraphic context.

Figure 4-2. $\delta$ D values of samples colored by preparation method (Red square is Method 1, Blue circle is Method 2). Vertical error bars are intrareplicate ranges (2-6 replicates per point).

Figure 5-1. A plot of all Rattlesnake $\delta$ D values. Pink squares are Method 1 and blue circles are Method 2. Samples 019, 039 and $019 \mathrm{f}$ were all collected from the same outcrop. Sample 019f is unique due to being composed of very friable, large grained clear-white glass shards, which has been interpreted as precursory ash-fall (Streck and Grunder, 1997). Samples 019, 038, 021 and 039 are all from the non-welded ignimbrite base and were similar in texture and outcrop characteristics. Samples 021 and 038 are from different locations. 


\section{INTRODUCTION}

Stable isotopic ratios of paleoprecipitation derived from various proxies help elucidate an area's relative change in climate and elevation through time (e.g. Bershaw et al., 2010; Garzione et al., 2000; Kohn et al., 2002; Kohn and Law, 2006; Takeuchi and Larson, 2005; Poage and Chamberlain, 2001; Chamberlain et al., 2012; Cassel et al., 2014; Canavan et al., 2014). The use of deuterium content of environmental water within hydrated volcanic glass has great paleoenvironmental potential, largely due to the widespread and relatively instantaneous deposition and hydration of volcanic ash (Nolan and Bindeman, 2013). Ash deposits (tuff) also typically have dateable phenocrysts and can be spatially correlated based on composition (Cassel and Breecker, 2017; Fisher and Schmincke, 1984). Volcanic glass particles hydrate readily upon deposition if they are exposed to environmental water (Friedman, Gleason, Sheppard, et al., 1993; Nolan and Bindeman, 2013; Dettinger and Quade, 2015; Friedman and Long, 1976). However, the ability of glass to preserve original environmental water $\delta \mathrm{D}$ values over geologic time is debated (Nolan and Bindeman, 2013; Cassel and Breecker, 2017; Dettinger and Quade, 2015; Anovitz et al., 2009). Nonetheless, this paleowater proxy has been applied across the globe, including in the western United States (Figure 1-1). In this study, I analyzed volcanic glass samples from the lee side of the Cascade Range using two separate sample preparation protocols: one similar to Seligman et al. (2016) and Dettinger and Quade (2015), while the other follows Cassel and Breecker (2017). 
The comparison of these two datasets to each other and past

paleoenvironmental studies aids in determining the impact of sample preparation procedures, as well as the applicability of the volcanic glass proxy. Additionally, these results add to the growing body of isotopic data that can be used to constrain the topographic evolution of the Cascade Arc and paleoclimate of the region.

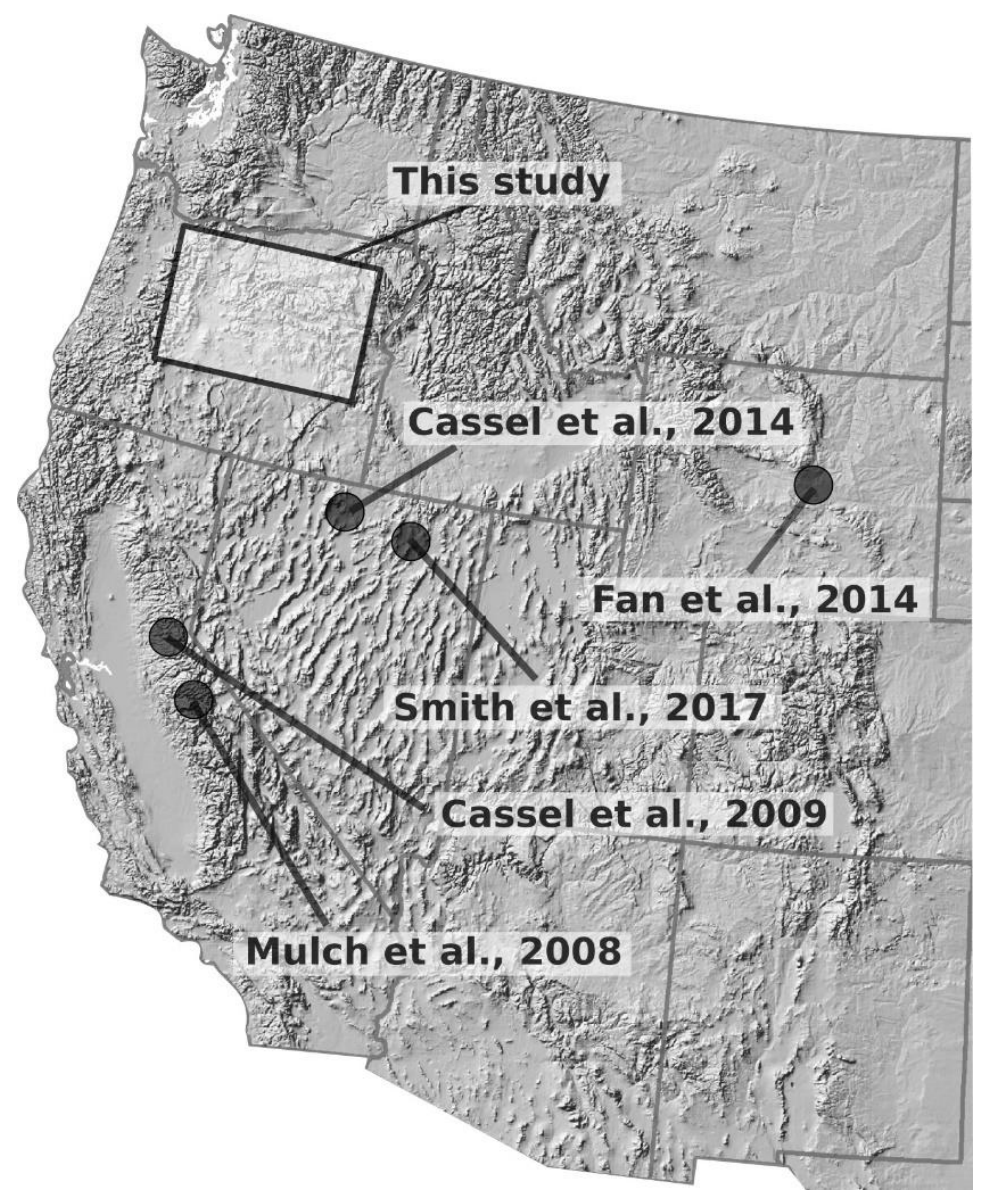

Figure 1-1. Hillshade map of the Western United States with approximate area of this study outlined as a black rectangle. Locations of volcanic glass paleowater proxy studies are shown (Cassel et al., 2014, 2009; Smith et al., 2017; Mulch et al., 2008; Fan et al., 2014). There is a conspicuous lack of volcanic glass proxy data for the northwestern US. Although Mazama ash in Oregon has been studied by Seligman and others (2016), it is not included here because all samples are $<10 \mathrm{Ka}$. 


\section{BACKGROUND}

\subsection{Volcanic Glass as a Paleowater Proxy}

A material can be used as a paleowater proxy if it retains the original isotopic signal of paleowater and the timing of hydration can be estimated. Studies focused on changes in height of orographic barriers (paleoelevation, or paleoaltimetry), typically use changes in isotopic compositions through geologic time to estimate changes in elevation (Rowley, 2007). Volcanic glass is thought to incorporate and preserve environmental water soon after emplacement and has been used extensively as a paleowater proxy. The incorporation of environmental water is likely influenced by its formation history and texture (Fisher and Schmincke, 1984; Friedman, Gleason, Wilcox, et al., 1993; Martin et al., 2017).

\subsubsection{Volcanic Glass Formation}

Ash-producing volcanism can create fine-grained volcanic glass fragments (Figure 2-1). As magma ascends, pressure decreases and dissolved volatiles begin to exsolve, forming bubbles (Fisher and Schmincke, 1984). These bubbles can be preserved in glass as the magma quenches. Ash becomes fragmented during eruption and deposition, creating "bubble wall shards", or "matrix shards", which are the broken conjunctions of adjoining bubbles (Figure 2-1). Bubble-wall shards are mostly broken vesicle walls of pumice, a highly vesiculated form of volcanic glass. These shards are associated with explosive silicic eruptions, which can distribute volcanic glass over large areas as ash-falls and ash-flows. Volcanic ash is composed of vitric (glassy), crystal, and lithic (rock fragment) components. The 
word "tuff" is also used to describe pyroclastic deposits (Fisher and Schmincke, 1984).

Post-emplacement processes including devitrification, vapor-phase crystallization, fracturing, and welding during cooling can cause textural differences within a cooling unit. Devitrification and mineral formation may occur shortly after emplacement at elevated temperatures, typically toward the center and top of an ignimbrite flow (Keating, 2005 and references therein). Non-welded tuffs are typically friable and show no evidence of deformation within pumice fragments or glass shards. They have higher permeability, increasing the likelihood of interaction and hydration with meteoric water (Fisher and Schmincke, 1984; Casey, 2008; Gin et al., 2013). In ignimbrites, this texture is often found in the basal section. Incipiently welded tuffs are more coherent, but do not display internal deformation and glass shards are not coalesced. The matrix of partially welded tuffs tends to still have some porosity. Densely welded samples have a general lack of pore space and may appear obsidian-like (Streck and Grunder, 1995). Densely welded samples typically do not hydrate with environmental waters due to low permeabilities (Fisher and Schmincke, 1984). 


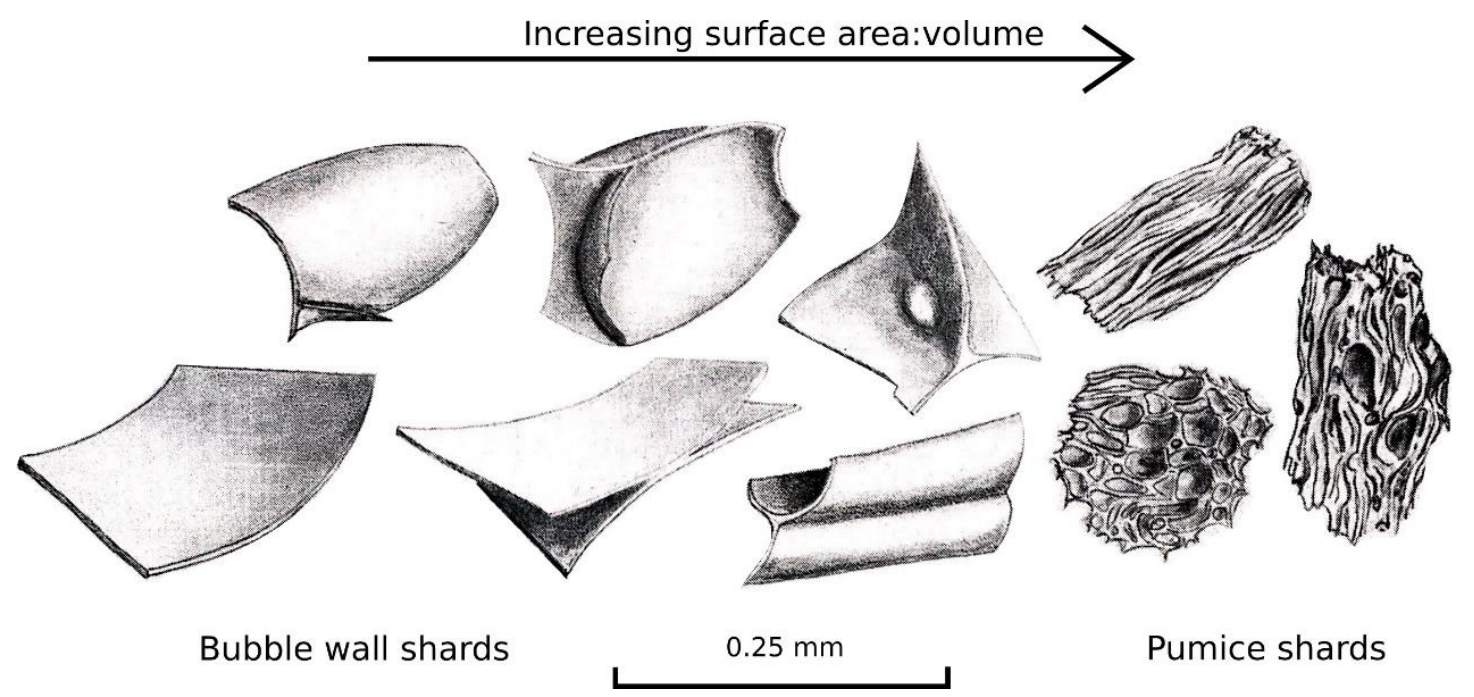

Figure 2-1. Sketches of common glass shard morphologies ranging from bubble wall shards to pumice shards. Cuspate or lunate fragments of broken bubble walls that are ' $Y$ ' shaped in cross-section are typically a junction of three bubbles or two concave plates of adjoining bubbles. Flat plates are broken from the wall of a large, flattened vesicles. Pumiceous fragments may have round or elongate cavities. Figure and caption adapted from Fisher and Schmincke (1984).

\subsubsection{Water Content of Glass Shards}

\section{Degassing and melt inclusions}

Deuterium composition of water from volcanic glass is measured in per mille (parts per thousand, \%o) deviations from standard mean ocean water (SMOW). Immediately following deposition, ash contains bubble wall (matrix) glass shards with $\sim 0.1-0.6$ wt. \% residual magmatic water following degassing during ascent (Friedman, Gleason, Wilcox, et al., 1993; Seligman et al., 2016). Magmatic water deuterium values $(\delta \mathrm{D})$ range from $-90 \%$ for hotspot environments, to $-40 \%$ for subduction environments, with an estimated $-60 \%$ for the convecting mantle (Kyser and O'Neil, 1982; Taylor, 1974; Harford and Sparks, 2001; Loewen and Bindeman, 2015; Clog et al., 2013). Residual magmatic water tends to be isotopically positive compared to meteoric waters which are typically $\sim-100 \%$ in the lee of the 
Cascade Arc (Figure 2-2). However, the composition of residual magmatic water can vary considerably ( 100\%) depending on formation history (Martin et al., 2017). Relatively low water content samples ( $<1.5 \mathrm{wt}$. \% water) have high $\delta \mathrm{D}$ values, consistent with a significant contribution of magmatic water to the overall measured isotopic value (Seligman et al., 2016).

Melt inclusions in phenocrysts, which retain volatiles during ascent and degassing of glass (Schiano, 2003), may contain $\sim 4-6$ wt. \% water of magmatic composition. When targeting meteoric paleowaters, it is important to remove these phenocrysts from the ash before analysis (Cassel and Breecker, 2017).

\section{Hydration of glass by environmental waters}

Amorphous glass is thermodynamically unstable compared to mineral phases and is prone to aqueous corrosion (e.g. dissolution, rehydration, and secondary mineral formation) (Fisher and Schmincke, 1984; Sheppard and Gude, 1968) (Figure 2-3). Alteration is dependent on environmental conditions such as temperature and composition of pore fluids and glass. If the rock is permeable enough for water-glass interaction, meteoric water diffuses into the glass structure. The rate of hydration decreases with time, suggesting that the water composition of hydrated volcanic glass is largely determined by meteoric waters early in the hydration process (Friedman, Gleason, Sheppard, et al., 1993; Nolan and Bindeman, 2013). The mechanism responsible for water absorption in glass is not well understood, but appears to be the result of removal and replacement of large-radius ion sites within the glass with $\mathrm{H}^{+}$and D ions (Casey, 2008; Valle et al., 2010; 
Cailleteau et al., 2008; Cassel and Breecker, 2017) (Figure 2-3).

Natural, felsic glasses rarely contain more than $10 \%$ water, and typically contain 2-6 wt. \% (Friedman, Gleason, Sheppard, et al., 1993; Cassel and Breecker, 2017; Seligman et al., 2016). Water concentration correlates negatively with $\delta D_{\text {glass }}$ value, as relatively depleted meteoric water overprints the residual magmatic signal (Seligman et al., 2016). In the case of a sample containing a $0.6 \mathrm{wt}$ \% residual magmatic water and $2 \mathrm{wt}$ \% water total, magmatic water could account for up to $\sim 30 \%$ of the total water content. Some studies attempt to estimate the composition and amount of magmatic water in the samples by analyzing non-hydrated glass (Seligman et al., 2016) or using numerical models and thermogravimetry (Giachetti et al., 2015; Giachetti and Gonnermann, 2013; Martin et al., 2017), while others select only samples $>2 \mathrm{wt}$. \% water and consider the possible contribution of magmatic water to be negligible (Cassel and Breecker, 2017; Friedman, Gleason, Sheppard, et al., 1993; Fan et al., 2014). 


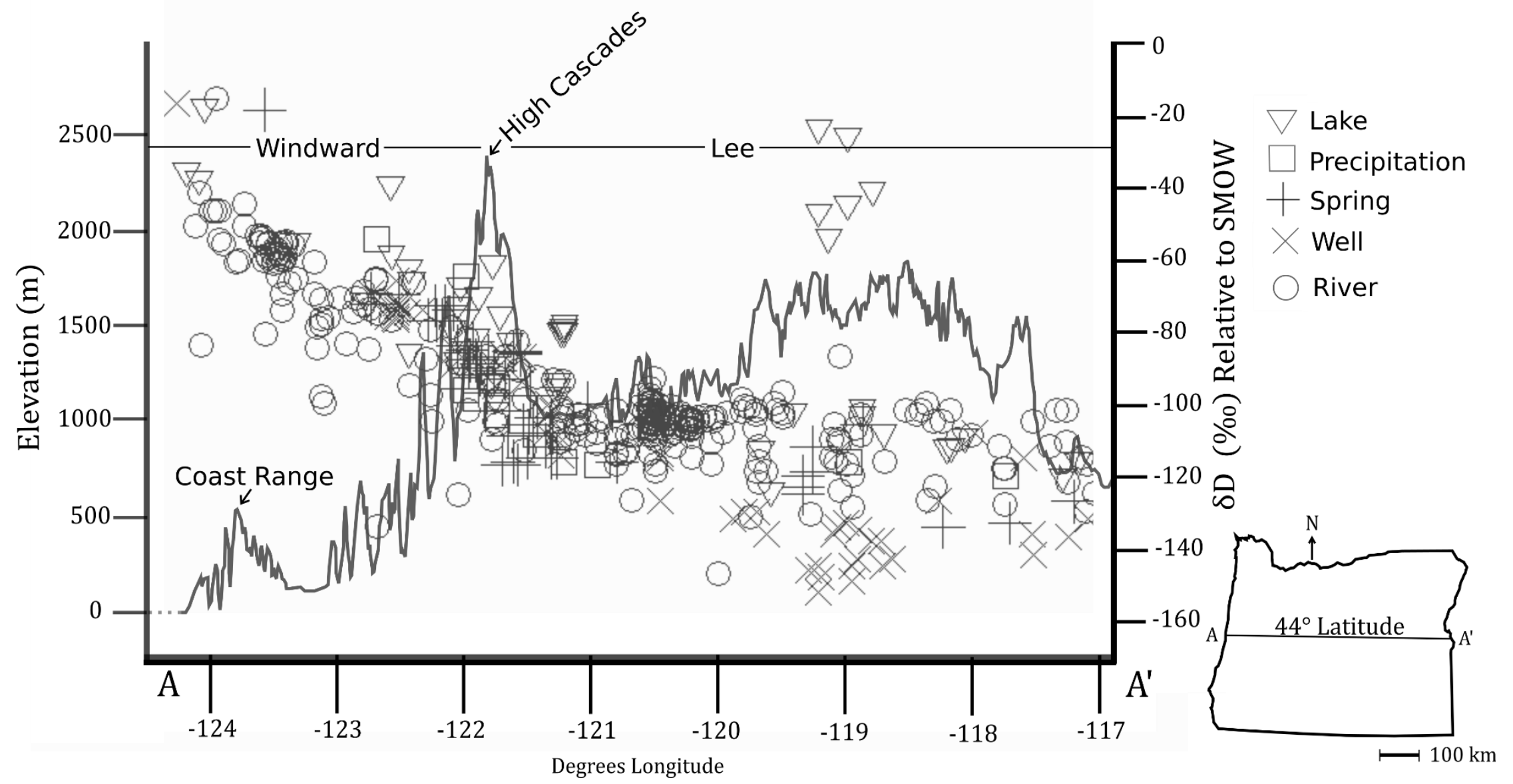

Figure 2-2. Elevation profile of Oregon along a transect at $44^{\circ}$ latitude (gray line). Modern deuterium $(\delta D)$ values relative to standard mean ocean water (SMOW) in central to northern Oregon and southern Washington are plotted with their respective longitude, indicated by various shapes (Coplen and Kendall, 2000; Ingebrisen et al., 1988; Friedman, 2000; Friedman et al., 2002; IAEA, b) 
The conditions under which ash is deposited and hydrated can vary widely depending on eruption dynamics and physical environment. For example, Cassel and Breecker (2017) determine that Eocene glasses from lacustrine samples in northeastern Nevada can be enriched by $>100 \%$ relative to samples hydrated by fluvial or precipitation water (Cassel and Breecker, 2017). On the lee side of the Cascade Range $\left(\gtrsim-121.5^{\circ}\right)$, evaporation causes variability in meteoric water $\delta \mathrm{D}$ values due to aridity in the rainshadow of the Cascades. The average precipitation or stream water sample in the lee of the Range is $-104 \%$, while evaporatively enriched lake samples can be as positive as -20\%o (Figure 2-2).

This equation allows the estimation of environmental water $\delta \mathrm{D}$ content from the $\delta \mathrm{D}$ value measured in volcanic glass. The lighter isotope more readily incorporates into the amorphous glass structure and causes a -30 \% shift in the isotopic ratio of water in glass relative to meteoric waters (Friedman, Gleason, Sheppard, et al., 1993). 


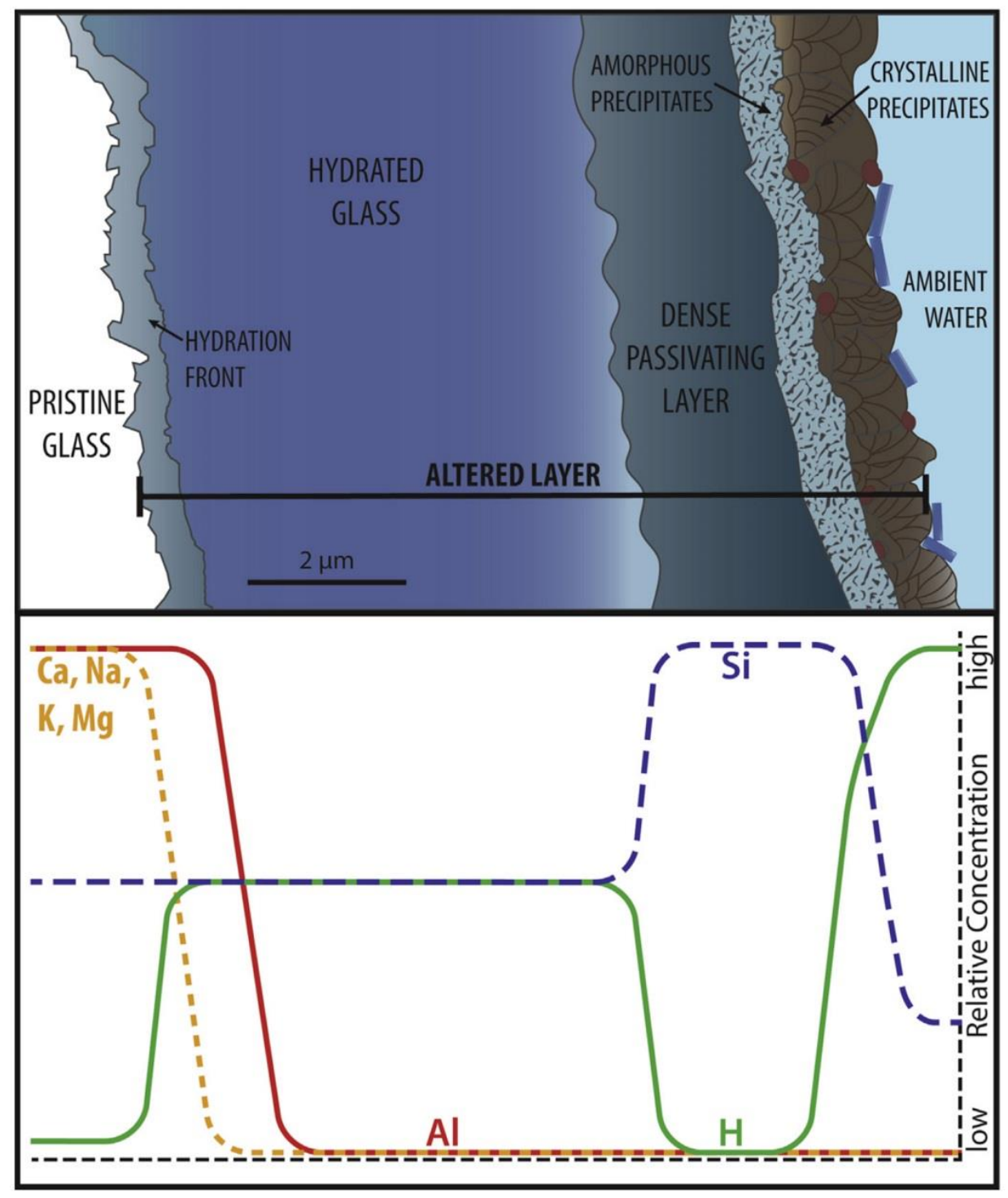

Figure 2-3 Top: A schematic figure of the altered layer of volcanic glass, including the metal-ion depleted hydrous region in the glass interior that retains original covalent bonds, the microporous silica-rich layer near the exterior surface (gel or passivating layer), and the crystalline and amorphous reaction products precipitated at the surface of the glass. Bottom: Relative distribution of major elements through the altered layer. Figure and caption from Cassel and Breecker (2017) and references therein.

An estimation of the fractionation factor between environmental water and

felsic volcanic glass has been empirically derived by Friedman, et al. (1993).

$$
\delta D_{\text {environmental water }}=\frac{\left(1000+\delta D_{\text {glass }}\right)}{0.967}-1000
$$


Though the fractionation factor in Eq. (1) assumes surface temperature and pressure, the cooling history of ash deposits is variable, which may impact glass $\delta \mathrm{D}$ values. Ash temperature at the time of hydration depends largely on unit thickness, initial deposition temperature, and deposition timing, (Martin et al., 2017; Fisher and Schmincke, 1984). For an ash-flow tuff, emplacement temperature can vary from 100 to $950{ }^{\circ} \mathrm{C}$ (Keating, 2005). At the slowest cooling rate, an $80 \mathrm{~m}$ thick ignimbrite sheet would reach surface temperatures within 3 years. Therefore, the effects of elevated temperature and vapor-phase meteoric water are not likely to significantly impact isotopic composition of fully hydrated glasses, which take $10^{3}$ $10^{4}$ years to reach full hydration (Cassel and Breecker, 2017). However, work by Martin and others (2017), suggests that some units can remain at a few hundred ${ }^{\circ} \mathrm{C}$ for years to hundreds of years, in which case rehydration would occur faster, completing within months to years. Accelerated hydration could cause measured $\delta \mathrm{D}$ values to be affected by climate fluctuations over relatively short periods of time, potentially increasing noise in long-term climate records. Research suggests the empirically derived fractionation equation for converting $\delta \mathrm{D}$ values of water to glass (Eq. 1) may vary depending on cooling history, composition, and/or wt. \% water (Stauffer and Cassel, 2017; Martin et al., 2017).

Within $10 \mathrm{ka}$, a silica-rich and insoluble oxide-depleted "gel layer" or "passivating layer" forms on the outermost surface of glass shards due to the reorganization of silica bonds and release of soluble elements via corrosion (Figure 2-3). Upon formation, the diffusion rate decreases by 3 - 5 orders of magnitude (Valle et al., 2010; Cailleteau et al., 2008). Cailleteau et al. (2008) demonstrated that 
the "gel layer" is not as effective of a barrier with the addition of insoluble oxide constituents, which could be a concern for naturally occurring ash. However, Fournier and others (2014) suggest that if the gel layer is rendered ineffective, glass corrosion would resume, which would likely destroy isotropic glass shards.

\section{Re-equilibration with modern water}

Laboratory studies show that $\delta \mathrm{D}$ values of ash samples re-equilibrate with unnaturally isotopically heavy water $(650-18,205 \%$ o $\delta)$ over laboratory timescales at relatively low temperatures $\left(20-70^{\circ} \mathrm{C}\right)$ (Nolan and Bindeman, 2013; Anovitz et al., 2009). This suggests that similar-to-modern $\delta \mathrm{D}$ paleowater values could be due to re-equilibration with modern water (e.g. Canavan et al., 2014).

There is evidence in the rock record that re-equilibration with more recent environmental water is not occurring. For example, glasses of Eocene age but differing depositional environments (lacustrine vs. fluvial) exhibit significantly different isotopic values ( $>100 \% 0 \delta \mathrm{D})$, despite being exposed to similar postdepositional meteoric waters for millions of years (Cassel and Breecker, 2017).

Hydrofluoric acid (HF) abrasion and heavy liquid separation may allow the derivation of original isotopic composition of meteoric paleowater soon after ash deposition. Otherwise, hydrous contaminants that more readily re-equilibrate with post-depositional environmental waters may affect isotopic results and subsequent paleoenvironmental interpretations (Gin et al., 2015). Contamination can significantly impact the overall measured $\delta$ D value, because some precipitates on shard surfaces can hold significantly more water (12-36 wt. \%) than glass (2-10 wt.

\%) (Cassel and Breecker, 2017). 


\subsubsection{Sample Preparation Methods}

There are three key differences between volcanic glass preparation methods used by previous researchers that we address in our experimental design described in Section 3. They are 1) Hand selection versus heavy liquid separation of grains; 2) Hydrofluoric acid abrasion versus sonication of grains; and 3) filtering of different grains size fractions.

\section{Hand selection vs. heavy liquid separation}

Some studies (Seligman et al., 2016; Rohrmann et al., 2016; Pingel et al., 2014) use hand selection of shards under a microscope, while others (Cassel and Breecker, 2017; Sarna-Wojcicki, 1984; Mulch et al., 2008; Smith et al., 2017) use heavy liquid separation. Creating a density gradient column within a separatory funnel (see Section 3.1, and Cassel and Breecker, 2017) allows for precise separation of constituents by density. Pumiceous glass tends to float above matrix shards, and matrix shards with adhering phenocrysts sink relative to those without. These adhering phenocrysts can be particularly problematic for some ashes, including Mazama ash which contains adhered micro-phenocrysts (Seligman et al., 2016). These minerals may have melt inclusions containing magmatic water, which deviate from environmental paleowater $\delta \mathrm{D}$ values (Kent, 2008; Moore, 2008; Cassel and Breecker, 2017). High surface area pumice fragments may act as preferential fluid pathways, increasing the likelihood for surface alteration and re-equilibration with more recent water (Cassel and Breecker, 2017; Fisher and Schmincke, 1984) (Figure 2-1). 
Another common variation in preparation protocol is whether hydrofluoric acid (HF) is used to abrade shard surfaces. Some studies (e.g. Smith et al., 2017; Cassel et al., 2014; Pingel et al., 2014; Rohrmann et al., 2016; Mulch et al., 2008) use $\mathrm{HF}$ and a combination of hydrochloric acid $(\mathrm{HCl})$ and/or sonication, while other studies (e.g. Seligman et al., 2016; Dettinger and Quade, 2015; Canavan et al., 2014) use sonication and may or may not use $\mathrm{HCl}$. $\mathrm{HF}$ abrasion causes significant differences in measured $\delta$ D values (Seligman et al., 2016; Cassel and Breecker, 2017; Dettinger and Quade, 2015). Whether HF abrasion is necessary for accurate paleoenvironmental studies is debated, as HF pretreatment has been shown to both increase (Dettinger and Quade, 2015; Seligman et al., 2016) and decrease intrareplicate variability (Cassel and Breecker, 2017).

Studies that exhibit changes in glass $\delta \mathrm{D}$ over laboratory timescales (e.g. Nolan and Bindeman, 2013; Anovitz et al., 2009) do not employ HF abrasion, and may be measuring $\delta \mathrm{D}$ of surface contaminants, which more readily exchange with environmental waters. These contaminants are often distributed heterogeneously on glass particles, which can cause large variability in measured values (wt. $\% \mathrm{H}_{2} \mathrm{O}$ and $\delta$ D) (Cassel and Breecker, 2017; Martin et al., 2017). HF abrasion removes surface contaminants and smooths surfaces (Cassel and Breecker, 2017).

\section{Grain size}

Selected grain size separates for volcanic glass analysis can vary from $<30$ $\mu \mathrm{m}$ to $>250 \mu \mathrm{m}$ (Cassel and Breecker, 2017; Seligman et al., 2016; Martin et al., 2017; Nolan and Bindeman, 2013; Dettinger and Quade, 2015). Smaller grains are more likely to be hydrated, but also more likely to be heavily altered or dissolve in ${ }_{14}$ 
acid. Larger shards may have pristine glass in the center with relatively positive $\delta \mathrm{D}$ values, low water content, and lower overall reproducibility, suggestive of a contribution of magmatic water from the center of larger shards (Seligman et al., 2016; Dettinger and Quade, 2015) (pristine glass in Figure 2-3). Large shards also may not completely degas during TC/EA analysis (Martin et al., 2017). Samples between 70-150 $\mu \mathrm{m}$ have been shown to be homogeneously hydrated ( $\geq 2 \mathrm{wt}$. \% water), even after repeated HF abrasion (Cassel and Breecker, 2017). 


\section{METHODS}

\subsection{Sample Preparation}

I analyzed multiple tuff samples using two distinct methods (Method 1 and Method 2) to test the effect of preparation protocol on $\delta \mathrm{D}$ results. The key differences between the two methods are summarized in Table 3-1 and include 1) Hand selection versus heavy liquid separation of grains; 2) Hydrofluoric acid abrasion versus sonication of grains; and 3) filtering of different grain size fractions. I analyzed nine samples from five units using Method 1, and 13 samples from ten units using Method 2. I compared samples from a total of five units using both methods.

Table 3-1. Summary comparing preparation Method 1 and Method 2

\begin{tabular}{|c|c|c|}
\hline & Method 1 & Method 2 \\
\hline $\begin{array}{l}\text { Similar method } \\
\text { reference }\end{array}$ & $\begin{array}{l}\text { Seligman and others (2016); } \\
\text { Dettinger and Quade (2015) }\end{array}$ & Cassel and Breecker (2017) \\
\hline Disaggregate samples & \multicolumn{2}{|c|}{ Hand crush in ceramic mortar and pestle } \\
\hline $\begin{array}{l}\text { Decrease size } \\
\text { variability }\end{array}$ & $\begin{array}{l}\text { Dry sieved (metal sieves) to } \\
125-212 \mu \mathrm{m}\end{array}$ & $\begin{array}{l}\text { Wet sieved (disposable sieves) to } \\
75-150 \mu \mathrm{m}\end{array}$ \\
\hline $\begin{array}{l}\text { Remove surface } \\
\text { contaminants }\end{array}$ & $\begin{array}{l}2 \times 30 \mathrm{sec} . \mathrm{HCl}(10 \%) \\
\text { sonicate in } \mathrm{DI} \text { water }>60 \mathrm{~min} .\end{array}$ & $\begin{array}{l}2 \times 30 \mathrm{sec} . \mathrm{HCl}(10 \%) \\
2 \times 30 \mathrm{sec} . \mathrm{HF}(8 \%)\end{array}$ \\
\hline Separate glass shards & Hand-pick shards & $\begin{array}{l}\text { Frantz magnetic separation, } \\
\text { LMT heavy liquid separation }\end{array}$ \\
\hline Check purity & $\begin{array}{l}\text { Check for minerals under } \\
\text { petrographic microscope }\end{array}$ & $\begin{array}{l}\text { Temporary immersion oil slides } \\
\text { under petrographic microscope to } \\
\text { check for mineral contaminants } \\
\text { and shard surface contaminants }\end{array}$ \\
\hline
\end{tabular}


Method 1

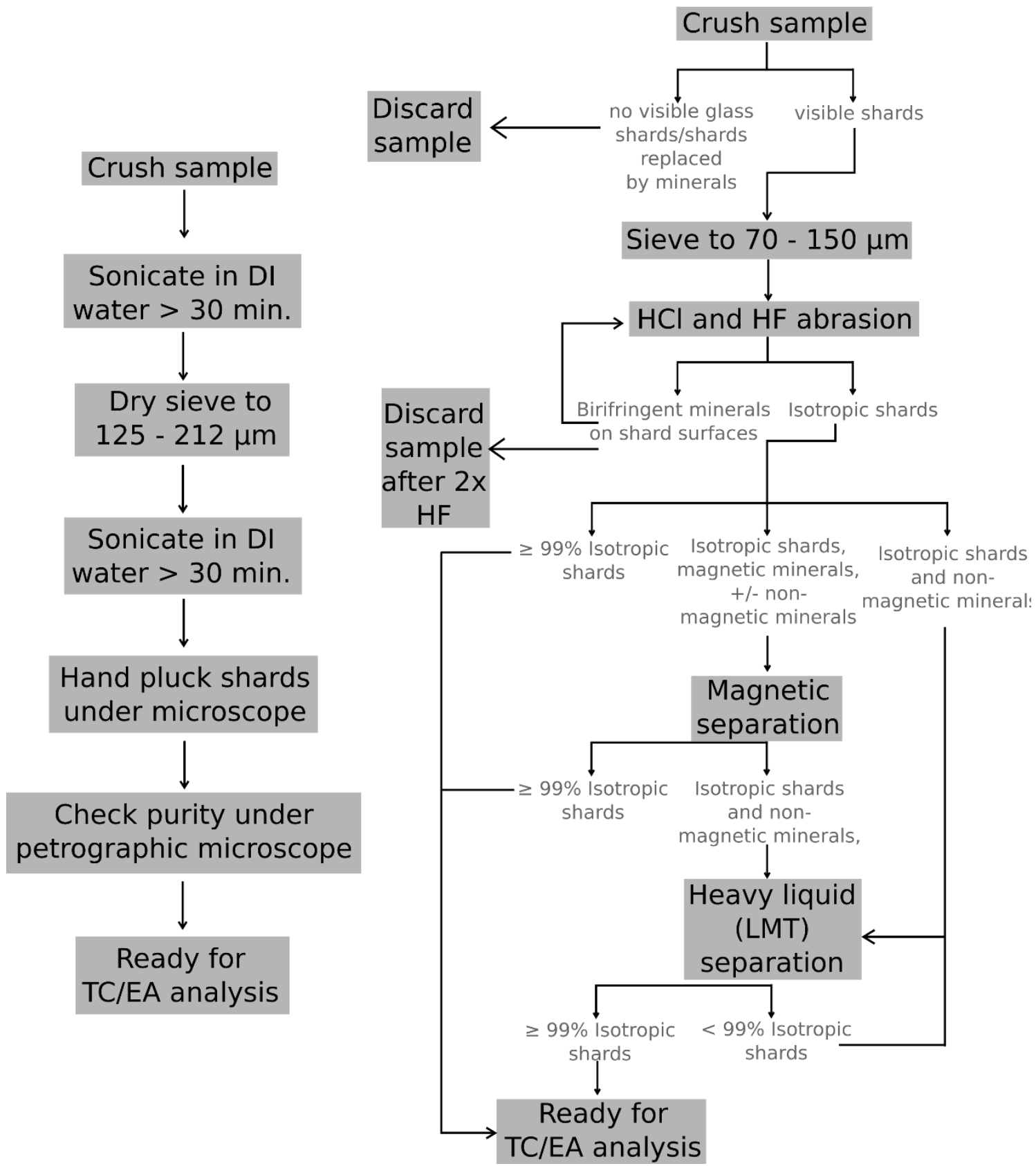

Figure 3-1. Comparative flow charts for Method 1 and Method 2. For Method 1, selected samples did not show evidence of devitrification under a hand sample microscope, and birefringent minerals were removed under petrographic microscope. For Method 2, purity was checked via temporary immersion oil slides after each step. Preparation is ceased at $\geq 99 \%$ isotropic glass in Method 2. See Appendix C, Figure C-3 for examples of sample separates at various stages of preparation. 


\subsubsection{Method 1}

Only samples that exhibit little to no evidence of devitrification under a hand sample and petrographic microscope were selected. I hand-crushed samples with a ceramic mortar and pestle and sonicated them for $>30$ minutes to remove clays. I dried samples and dry-sieved them to $125-212 \mu \mathrm{m}$. Treatment in $10 \%$ hydrochloric acid removes carbonates. I hand-selected $\sim 10 \mathrm{mg}$ of shards (enough for 2-3 replicates of 2-3 mg) based on morphology (Figure 3-2). I removed any birefringent grains under crossed polarized light. Large grain sizes made it difficult to discern mineral contamination on the shard surface with a petrographic microscope. The remaining grains were saved for analysis.

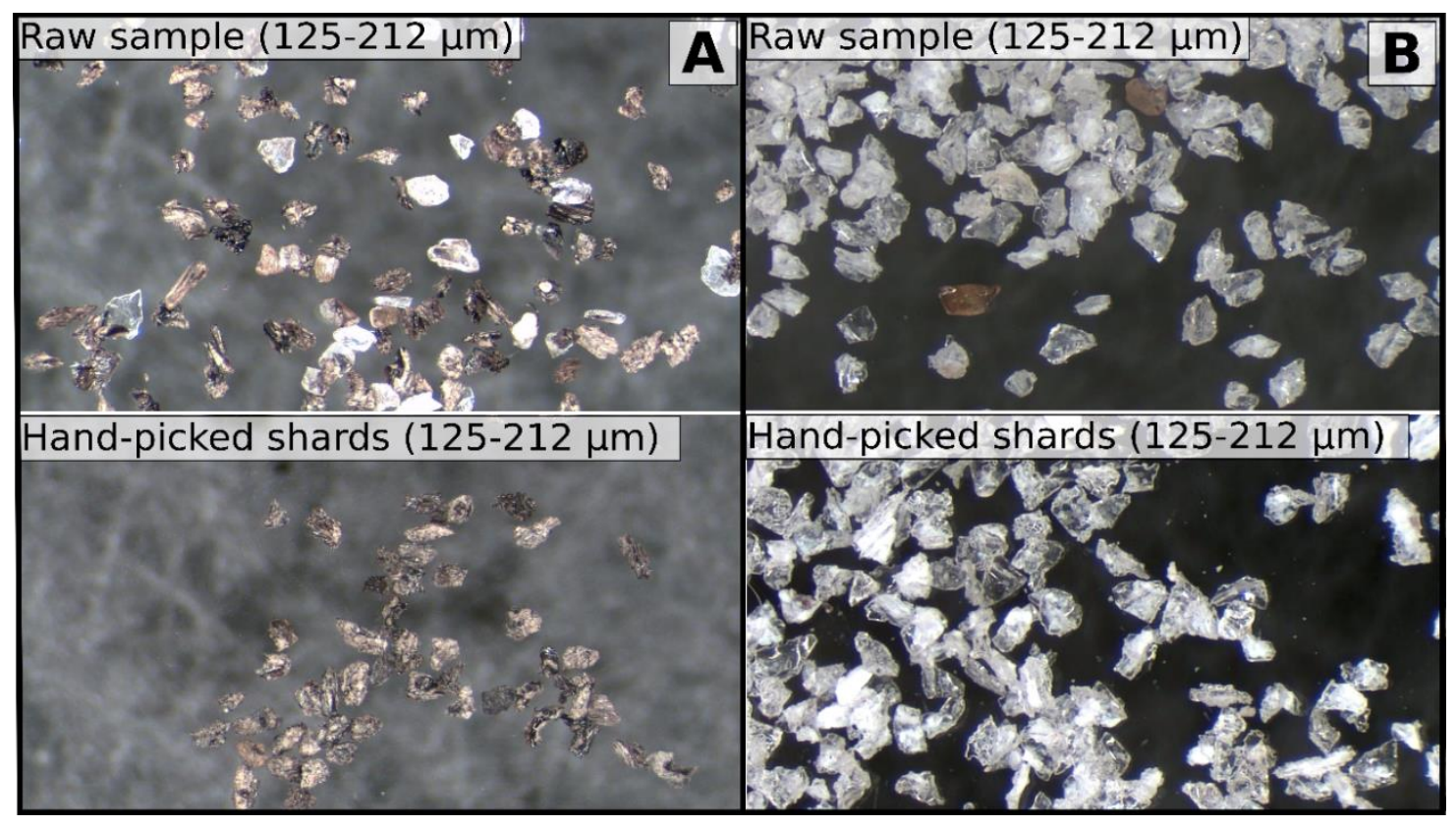

Figure 3-2. Examples of samples prepared using Method 1. A.) Sample M1-CVG014. Raw sieved sample (top) and hand-picked, $\mathrm{HCl}$ treated, and sonicated shards (bottom). B.) Sample M1-CVG019. Raw sieved sample (top) and hand-picked, $\mathrm{HCl}$ treated, and sonicated shards (bottom). 


\subsubsection{Method 2}

I crushed samples with a ceramic mortar and pestle and wet-sieved them to various size fractions $(<70 \mu \mathrm{m}, 70-150 \mu \mathrm{m}$, and $>150 \mu \mathrm{m})$. I checked the 70-150 $\mu \mathrm{m}$ size fraction for the presence of bubble wall shards and degree of alteration. To remove carbonates, all samples within this size fraction were treated with $10 \% \mathrm{HCl}$. I then abraded samples with $8 \% \mathrm{HF}$ to remove surface precipitates and altered glass, in addition to dislodging fragments that may be stuck together. Samples that appeared altered (ie: exhibiting birefringence in cross-polarized light) after two rounds of HF treatment were not analyzed. A small amount of sample was left after $\sim 2$ total minutes of $8 \% \mathrm{HF}$ abrasion, and samples that still showed evidence of alteration typically contained no isotropic glass.

I removed magnetic minerals using a hand magnet followed by a Frantz Isodynamic Separator (LB-1). If the separate did not produce $\geq 99 \%$ isotropic glass, I created density separates of pumiceous glass $\left(\rho \cong 0.70-2.25 \mathrm{~g} / \mathrm{cm}^{3}\right)$, bubble wall shards $\left(\rho \cong 2.35-2.50 \mathrm{~g} / \mathrm{cm}^{3}\right)$ and heavier minerals such as quartz and feldspar $(\rho \gtrsim$ $2.56 \mathrm{~g} / \mathrm{cm}^{3}$ ) using liquid lithium metatungstate (LMT) (Cassel and Breecker, 2017). Bubble wall shards were preferentially selected for analysis (Figure 3-3).

I routinely checked each sample for purity via petrographic analysis of immersion oil slides after each preparatory step and stopped when the sample contained $\geq 99 \%$ isotropic glass (Figure 3-3). Refer to Appendix C for a more detailed description. The steps required for each sample prepared according to Method 2 are displayed in Appendix E, Table E-2. 


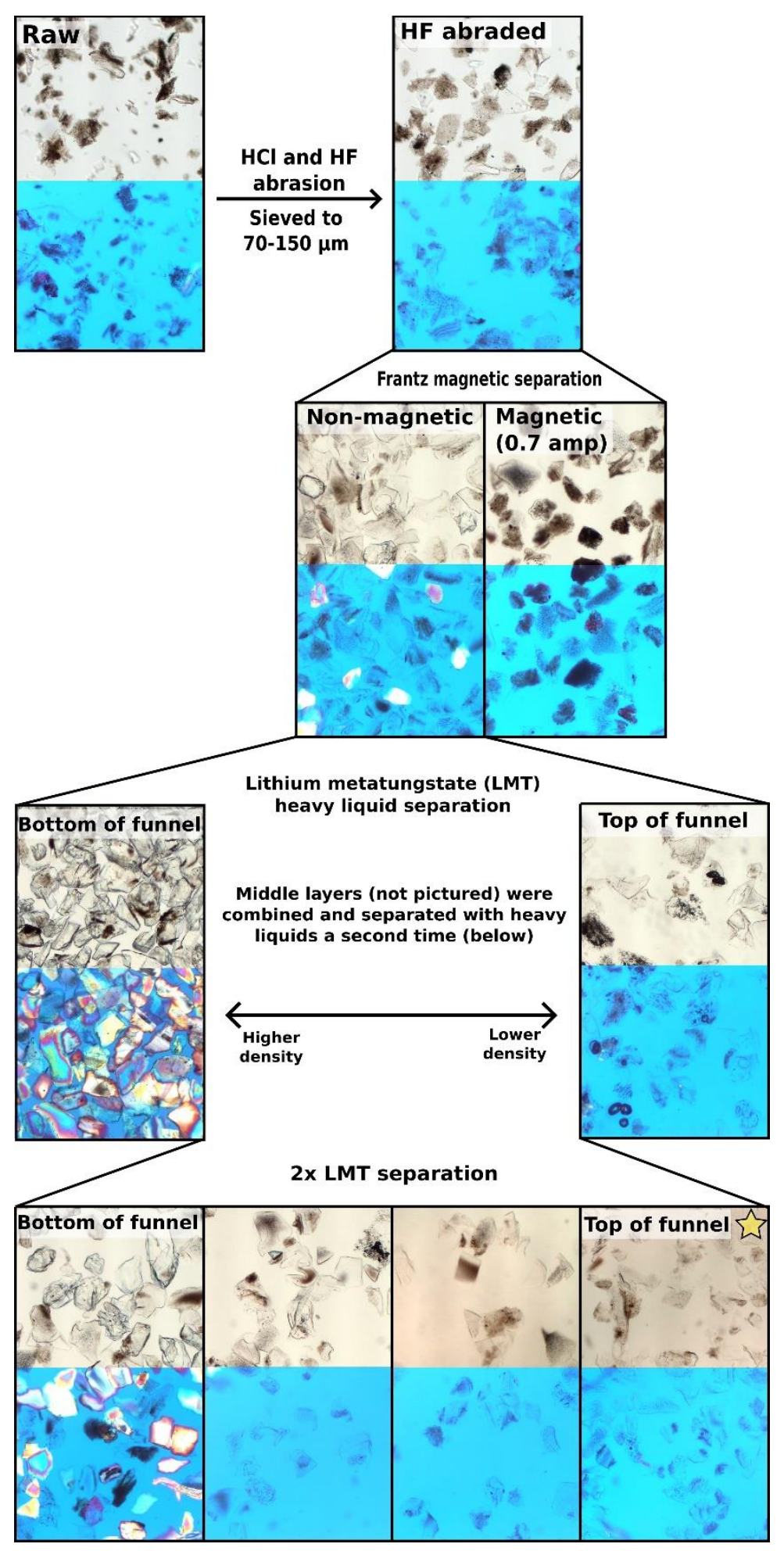

Figure 3-3. Temporary immersion oil slides of $~ 33 \mathrm{Ma}$ Tuff of Dale prepared with Method 2 (CVG013). The top left image is the raw sample, and the bottom right is $>99 \%$ pure glass (star). The top half of 
each photo is uncrossed polarized light, and bottom half is crossed polarized light with a full wave (1 $\lambda$ ) retardation plate (blue).

\subsection{Isotope Analyses}

Method 1 and Method 2 follow similar analytical procedure, with minor differences in standards. Analytical uncertainties for using a TC/EA and mass spectrometer are similar for both methods. $\delta \mathrm{D}$ uncertainty is $\sim \pm 2.5 \% 0(2 \sigma)$ and wt $\%$ water is $\sim 0.1$ wt. $\%(2 \sigma)$. Samples from Method 1 were analyzed at the University of Oregon Stable Isotope Laboratory. Analysis follows Seligman and others (2016). I analyzed Method 2 samples at the Light Stable Isotope Lab at the University of Texas at Austin generally following Cassel and Breecker (2017). Refer to Appendix D for a more detailed description of analytical methods.

\subsection{Sample Selection Overview}

In this study, I collected felsic volcanic ash samples ranging in age from $\sim 33$ Ma to $<0.1$ Ma throughout Oregon (maximum difference, $2^{\circ}$ latitude, $3.5^{\circ}$ Longitude) (Figure 3-4 and Table 3-2). I collected bulk samples ( 0.5-1 kg) from 5$10 \mathrm{~cm}$ beneath the surface exposures, with no visible evidence of weathering. Many samples were from outcrops described in the published literature, often with radiometric dates. Sample localities were typically not pursued if the word "glass" or "vitric" was not mentioned in published descriptions. Sample descriptions are summarized in Table 3-2, with additional details in Appendix B. 


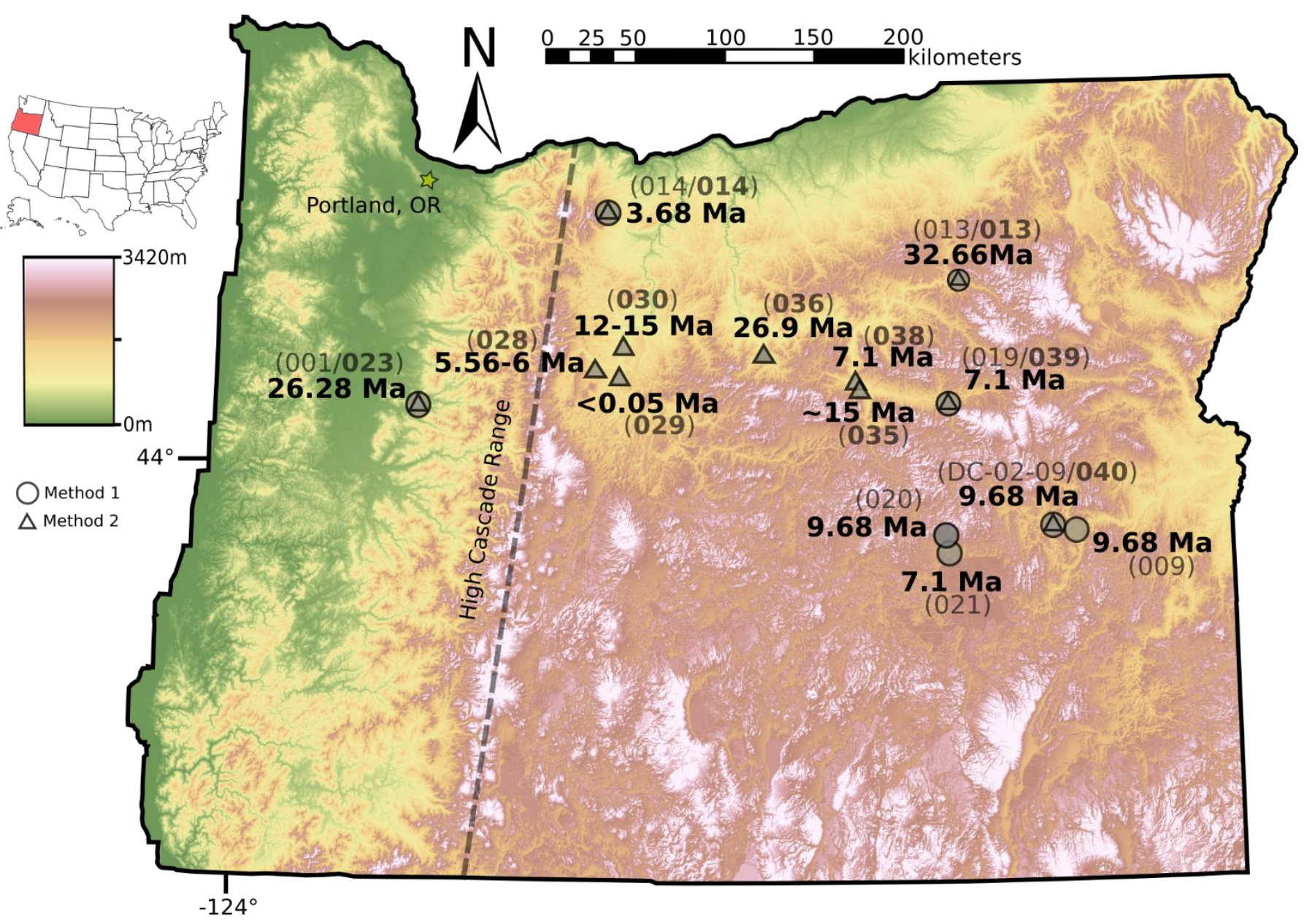

Figure 3-4. Elevation map of Oregon showing sample localities. Circles are samples prepared using Method 1 and triangles are Method 2. Numbers in parentheses are shortened sample identifiers, with bold font indicating preparation Method 2. 
Table 3-2. Location, age, and source information for analyzed samples. Prefixes indicate preparation Method 1 (M1) or Method 2 (M2) (bold), while asterisks $\left({ }^{*}\right)$ indicate samples that have been prepared using both methods. An overview of field interpretations is also included. See Appendix B for more detail.

\begin{tabular}{|c|c|c|c|c|c|c|c|c|c|}
\hline $\begin{array}{l}\text { Name / } \\
\text { Formation }\end{array}$ & ID & Age (Ma) & Lat & Long & $\begin{array}{l}\text { Welding } \\
\text { Texture }\end{array}$ & Field Notes & Type & $\begin{array}{l}\text { Hydration } \\
\text { Water }\end{array}$ & $\begin{array}{l}\text { Age/Location } \\
\text { Reference }\end{array}$ \\
\hline *Tuff of Dale & $\begin{array}{l}\text { M1-CVG013 } \\
\text { M2-CVG013 }\end{array}$ & $\begin{array}{l}32.66 \pm \\
0.36\end{array}$ & $\begin{array}{l}45.01314 \\
45.01314\end{array}$ & $\begin{array}{l}-118.89063 \\
-118.89063\end{array}$ & Welded & $\begin{array}{l}\text { Thick, massive unit, light gray, } \\
\text { fiamme, broken crystal } \\
\text { fragments }\end{array}$ & Ash flow & Precipitation & $\begin{array}{l}\text { Brown, 2017; } \\
\text { Ferns et al., } \\
\text { 2001; Savoie, } \\
2013\end{array}$ \\
\hline $\begin{array}{l}\text { Picture Gorge } \\
\text { Ignimbrite }\end{array}$ & M2-CVG036 & $\begin{array}{l}26.94 \pm \\
0.23\end{array}$ & 44.65694 & -120.26167 & Welded & $\begin{array}{l}\text { Thick, massive unit, gray, } \\
\text { sample taken near base }\end{array}$ & Ash flow & $\begin{array}{l}\mathrm{NA}-<1.5 \\
\text { wt. } \%\end{array}$ & $\begin{array}{l}\text { Retallack, et } \\
\text { al., } 2000\end{array}$ \\
\hline $\begin{array}{l}\text { *Tuff of } \\
\text { Foster Dam }\end{array}$ & $\begin{array}{l}\text { M1-CVG001 } \\
\text { M2-CVG023 }\end{array}$ & $\begin{array}{l}26.28 \pm \\
0.18\end{array}$ & $\begin{array}{l}44.41992 \\
44.41992\end{array}$ & $\begin{array}{l}-122.66532 \\
-122.66532\end{array}$ & Welded & $\begin{array}{l}\text { Thick, massive unit, light tan, } \\
\text { taken toward bottom of unit, } \\
\text { above carbonized wood }\end{array}$ & $\begin{array}{l}\text { Valley-filling } \\
\text { ash-flow }\end{array}$ & $\begin{array}{l}\text { Fluvial - } \\
\text { palustrine, } \\
\text { Precipitation }\end{array}$ & $\begin{array}{l}\text { McClaughry et } \\
\text { al., } 2010\end{array}$ \\
\hline $\begin{array}{l}\text { Mascall } \\
\text { Formation }\end{array}$ & $\begin{array}{l}\text { M2-CVG035 } \\
\text { M2-CVG034 }\end{array}$ & $17.6-14^{a}$ & $\begin{array}{l}44.50139 \\
44.49972\end{array}$ & $\begin{array}{l}-119.62500 \\
-119.62528\end{array}$ & $\begin{array}{l}\text { Non- } \\
\text { welded }\end{array}$ & $\begin{array}{l}1-3 \mathrm{~m} \text { beds, fine grained ash, } \\
\text { crystal poor, light gray (035) to } \\
\text { beige (034) }\end{array}$ & $\begin{array}{l}\text { Fluvially } \\
\text { reworked } \\
\text { ash-fall }\end{array}$ & $\begin{array}{l}\text { Fluvial, } \\
\text { Precipitation }\end{array}$ & $\begin{array}{l}\text { Bestland et al., } \\
2008, \\
\text { Fiebelkorn et } \\
\text { al., } 1983\end{array}$ \\
\hline $\begin{array}{l}\text { Simtustus } \\
\text { Formation }\end{array}$ & M2-CVG030 & $15-12^{a}$ & 44.69478 & -121.23000 & $\begin{array}{l}\text { Non- } \\
\text { welded }\end{array}$ & $\begin{array}{l}\text { Thin beds, fine grained ash, } \\
\text { within fluvial section of cross- } \\
\text { bedded tuffaceous sediments } \\
\text { above and below }\end{array}$ & $\begin{array}{l}\text { Fluvially } \\
\text { reworked } \\
\text { ash-fall }\end{array}$ & $\begin{array}{l}\text { Fluvial, } \\
\text { Precipitation }\end{array}$ & Smith, 1985 \\
\hline \multirow[t]{2}{*}{$\begin{array}{l}\text { Devine } \\
\text { Canyon Tuff }\end{array}$} & $\begin{array}{l}\text { M1-CVG009 } \\
\text { M1-DC02-09 } \\
\text { M2-CVG040b }\end{array}$ & $\begin{array}{l}9.68 \pm \\
0.03\end{array}$ & $\begin{array}{l}43.7728 \\
43.7835 \\
43.7831\end{array}$ & $\begin{array}{l}-118.1281 \\
-118.2845 \\
-118.2806\end{array}$ & $\begin{array}{l}\text { Partially } \\
\text { welded } \\
\text { (CVG009) } \\
\text { to non- } \\
\text { welded }\end{array}$ & $\begin{array}{l}\text { Densely welded (CVG009). } \\
\text { Massive, welded, off-white, } \\
\text { crystal-poor unit overlying } \\
\text { diatomite (DC02-09/CVG040) }\end{array}$ & $\begin{array}{l}\text { Ash-flow } \\
\text { deposited in } \\
\text { lacustrine } \\
\text { environment }\end{array}$ & Lacustrine & $\begin{array}{l}\text { Streck and } \\
\text { Ferns, 2004, } \\
\text { Green, } 1973\end{array}$ \\
\hline & M1-CVG020 & $\begin{array}{l}9.68 \pm \\
0.03\end{array}$ & 43.71241 & -119.00782 & Welded & Light gray, crystal rich & Ash-flow & $\begin{array}{l}\mathrm{NA}-<1.5 \\
\text { wt. } \%\end{array}$ & $\begin{array}{l}\text { Streck et al., } \\
1999\end{array}$ \\
\hline $\begin{array}{l}\text { *Rattlesnake } \\
\text { Tuff }\end{array}$ & $\begin{array}{l}\text { M1-CVG019 } \\
\text { M1-CVG019f } \\
\text { M1-CVG021 } \\
\text { M2-CVG038 } \\
\text { M2-CVG039 }\end{array}$ & $\begin{array}{l}7.05 \pm \\
0.01\end{array}$ & $\begin{array}{l}44.40818 \\
44.40818 \\
43.65925 \\
44.52121 \\
44.40818\end{array}$ & $\begin{array}{l}-118.98748 \\
-118.98748 \\
-118.99859 \\
-119.63343 \\
-118.98748\end{array}$ & $\begin{array}{l}\text { Non- } \\
\text { welded }\end{array}$ & $\begin{array}{l}\text { Non-welded, beige, taken near } \\
\text { base of outcrop, crystal poor, } \\
\text { poorly indurated, with brown } \\
\text { and clear shards ( } 019 f \text { is } \\
\text { coarser-grained, friable shards }\end{array}$ & $\begin{array}{l}\text { Ash flow } \\
\text { (019f, } \\
\text { precursory } \\
\text { fallout) }\end{array}$ & $\begin{array}{l}\text { Precipitation, } \\
\text { fluvial }\end{array}$ & $\begin{array}{l}\text { Streck and } \\
\text { Grunder, 1995, } \\
\text { Streck and } \\
\text { Ferns, } 2004\end{array}$ \\
\hline
\end{tabular}

N

coarser-grained, friable shards 


\begin{tabular}{|c|c|c|c|c|c|c|c|c|c|}
\hline $\begin{array}{l}\text { Deschutes } \\
\text { Formation }\end{array}$ & $\begin{array}{l}\text { M2-CVG027 } \\
\text { M2-CVG028 }\end{array}$ & $\begin{array}{l}5.99- \\
5.67^{a}\end{array}$ & $\begin{array}{l}44.58083 \\
44.58154\end{array}$ & $\begin{array}{l}-121.42503 \\
-121.42832\end{array}$ & $\begin{array}{l}\text { Non- } \\
\text { welded }\end{array}$ & $\begin{array}{l}\text { Massive, beige, fine-grained, } \\
\text { crystal-poor ash within cross- } \\
\text { bedded tuffaceous sediments } \\
\text { above and below }\end{array}$ & $\begin{array}{l}\text { Fluvially } \\
\text { reworked } \\
\text { ash-fall }\end{array}$ & $\begin{array}{l}\text { Fluvial, } \\
\text { Precipitation }\end{array}$ & $\begin{array}{l}\text { Pitcher et al., } \\
2017\end{array}$ \\
\hline $\begin{array}{l}{ }^{*} \text { Tuff of } \\
\text { Friend }\end{array}$ & $\begin{array}{l}\text { M1-CVG014 } \\
\text { M2-CVG014 }\end{array}$ & $\begin{array}{l}3.68 \pm \\
0.02\end{array}$ & $\begin{array}{l}45.36213 \\
45.36213\end{array}$ & $\begin{array}{l}-121.34188 \\
-121.34188\end{array}$ & Welded & $\begin{array}{l}\text { Dark gray, massive, fiamme, } \\
\text { glass is brown, only unit } \\
\text { outcropping in vicinity }\end{array}$ & Ash-flow & Precipitation & $\begin{array}{l}\text { McClaughry et } \\
\text { al., } 2016\end{array}$ \\
\hline $\begin{array}{l}\text { Quaternary } \\
\text { Ash }\end{array}$ & M2-CVG029 & $\begin{array}{l}0.055- \\
0.007^{a}\end{array}$ & 44.54448 & -121.25829 & $\begin{array}{l}\text { Non- } \\
\text { welded }\end{array}$ & $\begin{array}{l}\text { Massive, friable, light beige, } \\
\text { overlies } \sim 50 \mathrm{Ka} \text { intra-canyon } \\
\text { basalt flow }\end{array}$ & $\begin{array}{l}\text { Aeolian } \\
\text { reworked } \\
\text { ash }\end{array}$ & Precipitation & $\begin{array}{l}\text { Peterson and } \\
\text { Groh, } 1970\end{array}$ \\
\hline
\end{tabular}

a No radiometric age for sample. Age range based on dated samples within stratigraphic context

b Approximate location - sample taken on west side of Drinkwater Pass

* Sample analyzed using Method 1 and Method 2 of sample preparation 


\section{RESULTS}

\subsection{Comparison of Sample Preparation Methods}

\subsubsection{Volcanic Glass Weight Percent Water}

The intra-replicate range in water content is lower in samples prepared according to Method 2 (0.12 wt \%) compared to samples prepared using Method 1 (0.61 wt. \%)(, See Appendix E, Table E-3). The water content within a sample does not correlate with sample age $\left(\mathrm{R}^{2}=0.2\right)$ (Figure $\left.4-1\right)$. Weight percent water is related to sample texture, with welded samples having the least water (average $=$ 0.96 wt. \%) and non-welded to partially welded samples containing more water (average $=4.70$ wt. \%). Samples with $<1.5$ wt. \% water are exclusively welded samples. Samples with high water content ( $>4$ wt. \%) are less welded, varying from non-welded to partially welded.

Many samples analyzed using preparation Method 1 are between 2-4 wt. \% water (average $=3.54$ ), while samples analyzed using Method 2 cover a broader range from $\sim 2-8$ wt. $\%$ water (average $=4.79$ ). Most samples with higher water content (>4 wt. \%) prepared using Method 2 are non-welded ash samples with no Method 1 counterpart (e.g. $\sim 0 \mathrm{Ma}, 5 \mathrm{Ma}, 15$ - $16 \mathrm{Ma}$ ). Samples prepared using both methods include densely welded tuffs (M1-CVG020, M2-CVG036) with low water contents (<1.5 wt. \%) and high deuterium values ( -110\%) (Table 4-1). 
Table 4-1. Average $\delta \mathrm{D}(\%, \mathrm{VSMOW})$ and wt. \% $\mathrm{H} 2 \mathrm{O}$ of water extracted from replicates of each glass sample. Intra-replicate range is calculated from 2-6 replicates. Prefix M1/M2 signifies Method 1/Method 2, respectively, with Method 2 in bold. Samples with interpreted lacustrine hvdration water are denoted with an asterisk (*) next to the sample ID.

\begin{tabular}{|c|c|c|c|c|c|c|c|c|}
\hline $\begin{array}{l}\text { Name / } \\
\text { Formation } \\
\end{array}$ & ID & Welding & $\begin{array}{l}\text { Number of } \\
\text { replicates }\end{array}$ & Age (Ma) & $\begin{array}{c}\text { Average } \\
\mathrm{Wt} \% \mathrm{H}_{2} \mathrm{O} \\
\end{array}$ & $\begin{array}{c}\text { Range } \mathrm{H}_{2} \mathrm{O} \\
\text { (wt.\%) }\end{array}$ & $\begin{array}{l}\text { Average } \\
\bar{\delta} D(\% 0)\end{array}$ & $\begin{array}{c}\text { Range ōD } \\
(\% 0)\end{array}$ \\
\hline \multirow[t]{2}{*}{ Tuff of Dale } & M1-CVG013 & Welded & 4 & $32.66 \pm 0.36$ & 2.78 & 0.10 & -145.8 & 2.9 \\
\hline & M2-CVG013 & & 2 & & 3.67 & 0.04 & -155.4 & 0.2 \\
\hline $\begin{array}{l}\text { Picture Gorge } \\
\text { Ignimbrite }\end{array}$ & M2-CVG036 & Welded & 2 & $26.94 \pm 0.23$ & $1.16^{a}$ & 0.05 & -112.8 & 5.4 \\
\hline Tuff of Foster & M1-CVG001 & Welded & 4 & $26.28 \pm 0.18$ & $10.95^{b}$ & 4.50 & -118.0 & 12.3 \\
\hline Dam & M2-CVG023 & & 2 & & $12.83^{b}$ & 0.18 & -108.4 & 2.3 \\
\hline Mascall & M2-CVG035 & Non-welded & 2 & $17.6-14.8^{c}$ & 6.11 & 0.05 & -165.6 & 1.8 \\
\hline Formation & M2-CVG034 & & 2 & & 5.48 & 0.15 & -163.3 & 1.1 \\
\hline $\begin{array}{l}\text { Simtustus } \\
\text { Formation }\end{array}$ & M2-CVG030 & Non-welded & 2 & $15-12^{c}$ & 8.13 & 0.25 & -158.1 & 1.4 \\
\hline \multirow{5}{*}{$\begin{array}{l}\text { Devine } \\
\text { Canyon Tuff }\end{array}$} & M1-CVG009* & Partially welded & 2 & $9.68 \pm 0.03$ & 2.40 & 0.00 & -165.2 & 0.6 \\
\hline & & Non-welded & 2 & & 3.25 & 0.30 & -164.5 & 1.7 \\
\hline & M1-DC02-09* & Non-welded & 2 & & 4.17 & 0.43 & -132.1 & 1.4 \\
\hline & M2-CVG040* & & & & & & & \\
\hline & M1-CVG020 & Welded & 2 & & $0.75^{a}$ & 0.10 & -110.1 & 0.2 \\
\hline Rattlesnake & M1-CVG019 & & 4 & $7.05 \pm 0.01$ & 3.15 & 0.20 & -137.4 & 2.4 \\
\hline \multirow[t]{4}{*}{ Tuff } & M1-CVG019f & & 2 & & 2.60 & 0.00 & -173.3 & 0.5 \\
\hline & M1-CVG021 & Non-welded & 2 & & 3.15 & 0.10 & -128.4 & 0.0 \\
\hline & M2-CVG038 & & 2 & & 2.87 & 0.08 & -145.5 & 0.9 \\
\hline & M2-CVG039 & & 2 & & 2.99 & 0.05 & -143.6 & 0.9 \\
\hline Deschutes & M2-CVG027 & Non-welded & 2 & $5.99-5.67 c$ & 3.95 & 0.03 & -151.8 & 1.6 \\
\hline Formation & M2-CVG028 & & 2 & & 4.60 & 0.06 & -149.2 & 1.1 \\
\hline \multirow[t]{2}{*}{ Tuff of Friend } & M1-CVG014 & Welded & 2 & $3.68 \pm 0.02$ & 2.80 & 0.20 & -131.5 & 0.4 \\
\hline & M2-CVG014 & & 2 & & 3.07 & 0.00 & -134.0 & 2.3 \\
\hline $\begin{array}{l}\text { Quaternary } \\
\text { Ash }\end{array}$ & M2-CVG029 & Non-welded & 2 & $0.05-0 \mathrm{Mac}^{\mathrm{c}}$ & 3.19 & 0.19 & -151.3 & 1.1 \\
\hline
\end{tabular}

* Lacustrine hydration waters

c No radiometric age for sample. Age range based on dated samples

a Low water content (significant magmatic component)

within stratigraphic context

${ }^{\mathrm{b}}$ High water content (possible contamination) 


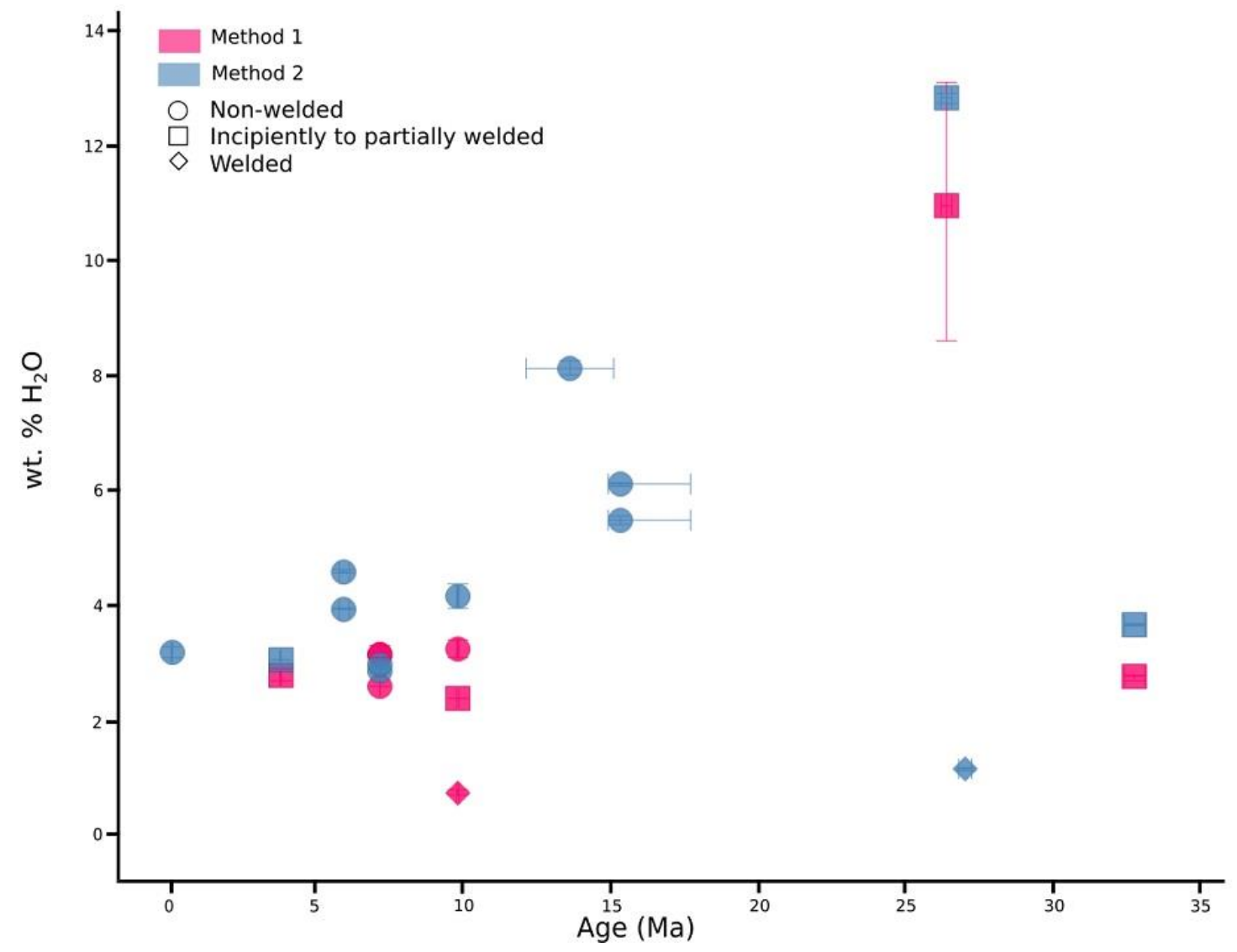

Figure 4-1. Average wt. \% $\mathrm{H}_{2} \mathrm{O}$ versus Age (Ma) for all analyzed samples. Vertical error bars indicate intra-replicate range of wt $\% \mathrm{H}_{2} \mathrm{O}$ measurements. Age ranges are $2 \sigma$ uncertainty based on radiometric dates or relative date range based on stratigraphic context.

There is no apparent relationship between water content and $\delta \mathrm{D}$ values for samples in Method $1\left(R^{2}=0.1\right)$. For Method 2, there is a trend $\left(R^{2}=0.5\right)$ of decreasing $\delta \mathrm{D}$ value with increasing water content, excluding the $>10 \mathrm{wt}$. \% Tuff of Foster Dam samples ( $\mathrm{R}^{2}=0.02$ if included) (Figure 4-1). 


\subsubsection{Volcanic Glass Deuterium Values}

The average intra-replicate range in $\delta \mathrm{D}$ for samples within $2-10 \mathrm{wt} \%$ is $<2 \%$ for both methods. Considering all samples from both methods, we do not observe a trend in $\delta \mathrm{D}$ values and age $\left(\mathrm{R}^{2}<0.1\right)$ (See Appendix E, Figure E-9).

I analyzed a total of five units using both preparation methods. However, I only separated three of these units to $>99 \%$ isotropic glass following Method 2 preparation. These are the Tuff of Friend (M1-CVG013, M2-CVG013), Rattlesnake Tuff (M1-CVG019, M2-CVG039), and Tuff of Dale (M1-CVG013, M2-CVG013). For all three sample sets, $\delta \mathrm{D}$ values are more negative with Method 2 compared to Method 1, with a larger discrepancy in older samples (Figure 4-2).

Exceptions to this are the 26 Ma Tuff of Foster Dam (CVG001/CVG023) and 9.7 Ma Devine Canyon (dc-02-09/CVG040) samples, which increased under Method 2 by $\sim 10 \%$ and 32\%o respectively. However, neither of these samples could be separated to $\geq 99 \%$ purity (Figure $4-2$ ).

For all samples prepared using both methods, the range in $\delta \mathrm{D}$ decreased by an average of $\sim 2.5 \%$ using Method 2 compared to Method 1 (or $0.7 \%$ for samples 2-10 wt. \%). The exception is the Tuff of Friend with a range that increased $1.9 \%$ under Method 2 (Appendix E, Table E-5). 


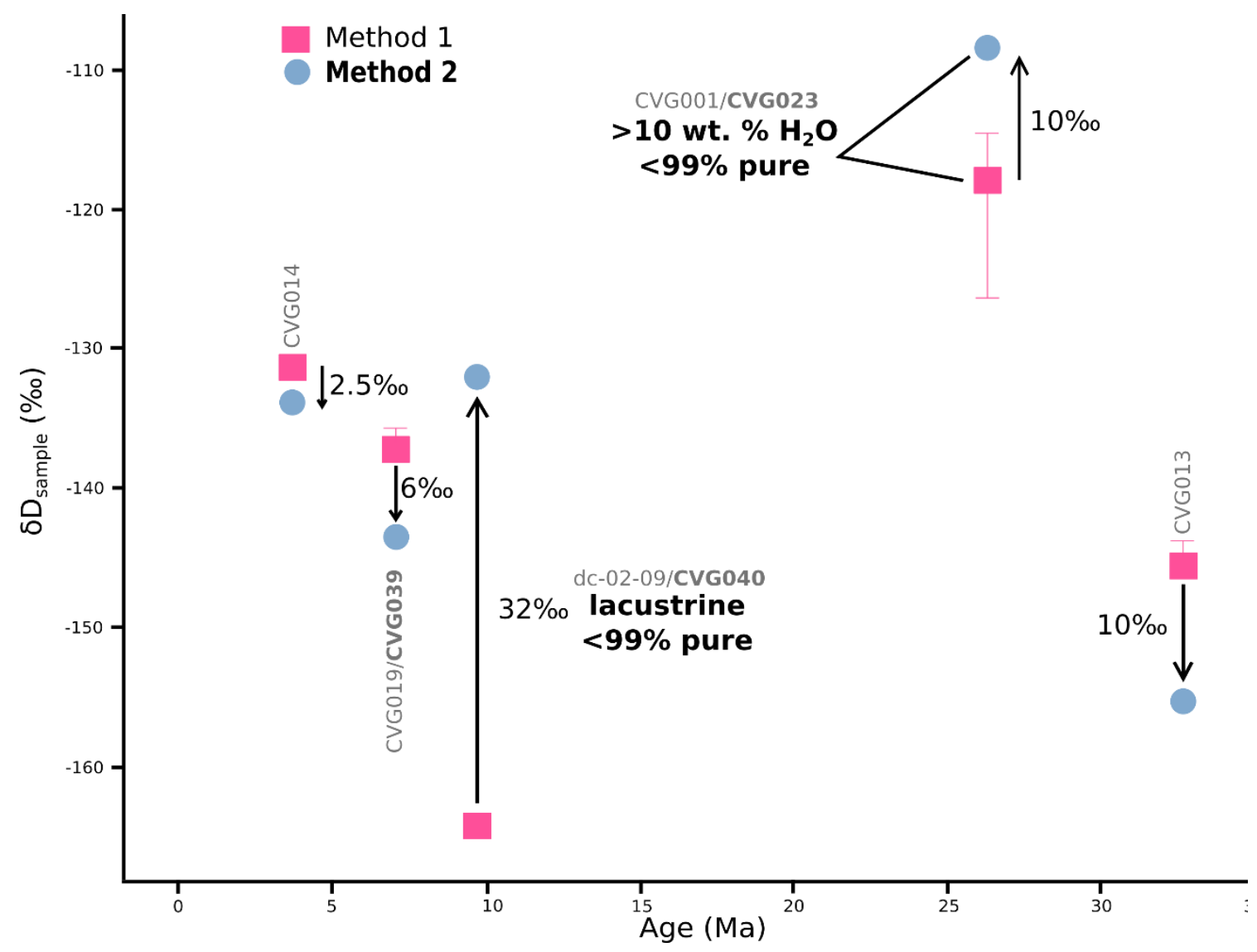

Figure 4-2. $\delta D$ values of samples colored by preparation method (Red square is Method 1, Blue circle is Method 2). Vertical error bars are intra-replicate ranges (2-6 replicates per point). 


\section{DISCUSSION}

\subsection{Isolating Paleowater Signals in Volcanic Glass}

Samples analyzed with both methods exhibit a general decrease in intrareplicate ranges in water content with Method 2 (0.14 wt. \% compared to $1.06 \mathrm{wt}$. \%) This suggests that HF abrasion removes spatially heterogeneous surface contaminants (Appendix E, Table E-4). Smaller grains in Method 2 compared to Method 1 (75 - $150 \mu \mathrm{m}$ vs. $125-212 \mu \mathrm{m})$ are more likely to have hydrated throughout the shard before the formation of a passivating layer, decreasing intrareplicate variability.

The Tuff of Foster Dam contained $>10$ wt. \% water using both preparation methods. Although the sample was never successfully separated to $\geq 99 \%$ purity, two rounds of HF abrasion during Method 2 caused a noticeable decrease in visible surface precipitates, largely due to the overall decrease in surface area. The intrareplicate range in water content of this sample decreased from $4.5 \mathrm{wt}$. \% to $0.18 \mathrm{wt}$. $\%$, suggesting that surface contaminants are heterogeneously distributed on shard surfaces and that they are removed through HF abrasion. Remaining sample material still exhibited birefringence, indicating that secondary minerals had replaced glass shards entirely. Because of the persistence of secondary minerals, this treated sample likely does not reflect paleowater $\delta \mathrm{D}$ values at the time of deposition, so is not suitable for paleoenvironmental reconstruction.

Intra-replicate variability in $\delta \mathrm{D}$ values also decreased in Method 2 samples compared to Method 1 (from 3.9\%o $\delta \mathrm{D}$ to $1.4 \%$ o $\delta$ ) (Appendix E, Table E-5). This is 
further evidence that HF removes spatially heterogeneous surface contaminants which cause more variability (Cassel and Breecker, 2017). Some of this reduction in $\delta \mathrm{D}$ variability may be due to the smaller grain sizes used in Method 2 compared to Method 1 (75 - $150 \mu \mathrm{m}$ vs. 125 - $212 \mu \mathrm{m})$. Larger grain sizes show more variation in $\delta \mathrm{D}$ values because they are not always consistently hydrated. This could lead to a significant isotopic contribution by the relatively positive magmatic water of the pristine shard interior. In addition, there is a negative correlation between water content and $\delta \mathrm{D}$ values $\left(\mathrm{R}^{2}=0.5\right)$. Welded samples with relatively low wt. \% water $(<1.5$ wt. \%) have $\delta$ D values that are anomalously high, regardless of method ( $110 \%$ ), suggesting that magmatic water is significantly affecting the isotopic composition of these samples. As a glass shard hydrates, the ratio of magmatic water to meteoric water decreases as water content increases (Seligman et al., 2016; Martin et al., 2017). Meteoric water $\delta \mathrm{D}$ values are negative relative to magmatic water (-104\%ovs. $\sim-50 \%$ ), causing a decrease in the overall $\delta \mathrm{D}$ of the shard as it is hydrated by environmental water. This is consistent with increased water content in HF abraded samples (5.35\% in Method 2 compared to $4.41 \%$ in Method 1) and decreased intra-replicate variability, as larger shards are less likely to become homogenously hydrated throughout before the formation of a passivating layer.

Results from preparation Method 2 are consistently more negative than both Method 1 results and average modern meteoric water values, suggesting that Method 2 removes surface contaminants influenced by modern water. The following 
$\delta \mathrm{D}$ values are estimated environmental water equivalents using Equation 1. Method 2 non-lacustrine glass separated to $>99 \%$ purity range from $-104 \%$ to $-137 \%$ o with an average of $-123 \%$, which is more negative than non-lacustrine modern water $\delta \mathrm{D}$, averaging -104\%o (fluvial and precipitation water, Table 4-1 and Figure 2-2). Alternatively, non-lacustrine Method 1 samples range from -98.7\%o to $116.7 \%$ with an average of $-114 \%$. Method 2 samples are $2.5-10 \%$ more negative than Method 1 for the three $\geq 99 \%$ pure samples that were analyzed using both methods, with older samples exhibiting a larger discrepancy than younger samples (Figure 4-2). I interpret this as the removal of contaminants via HF abrasion, leaving behind paleowater incorporated soon after ash deposition. The larger shift in older samples may be explained by more weathering and surface contamination. These results are consistent with other studies that show a systematic $\delta \mathrm{D}$ shift away from modern water values in acid-abraded samples (Cassel and Breecker, 2017; Sundell, 2017).

Lastly, samples from the same unit and the same locality showed significant discrepancies in $\delta \mathrm{D}$ when prepared using Method 1. I analyzed multiple $\sim 7 \mathrm{Ma}$ Rattlesnake Tuff samples with a range of textures (Figure 5-1). The most negative $\delta$ D value $(-173.3 \%$ ) came from a non-welded, friable, relatively coarse sample from near the base of the unit (M1-CVG019f). A second sample (M1-CVG019) with much higher $\delta \mathrm{D}$ value $(-137.4 \%$ ) was analyzed from the same outcrop, $\lesssim 0.5 \mathrm{~m}$ above and contains finer, non-welded, ash. Although these samples were within one stratigraphic meter of one another in a single outcrop, their isotopic compositions 
differ by over 30\%o. Surface contamination on sample M1-CVG019f is the likely cause for the large discrepancy, indicating that Method 1 may be inadequate for glass preparation (See Appendix C, Figure C-1).

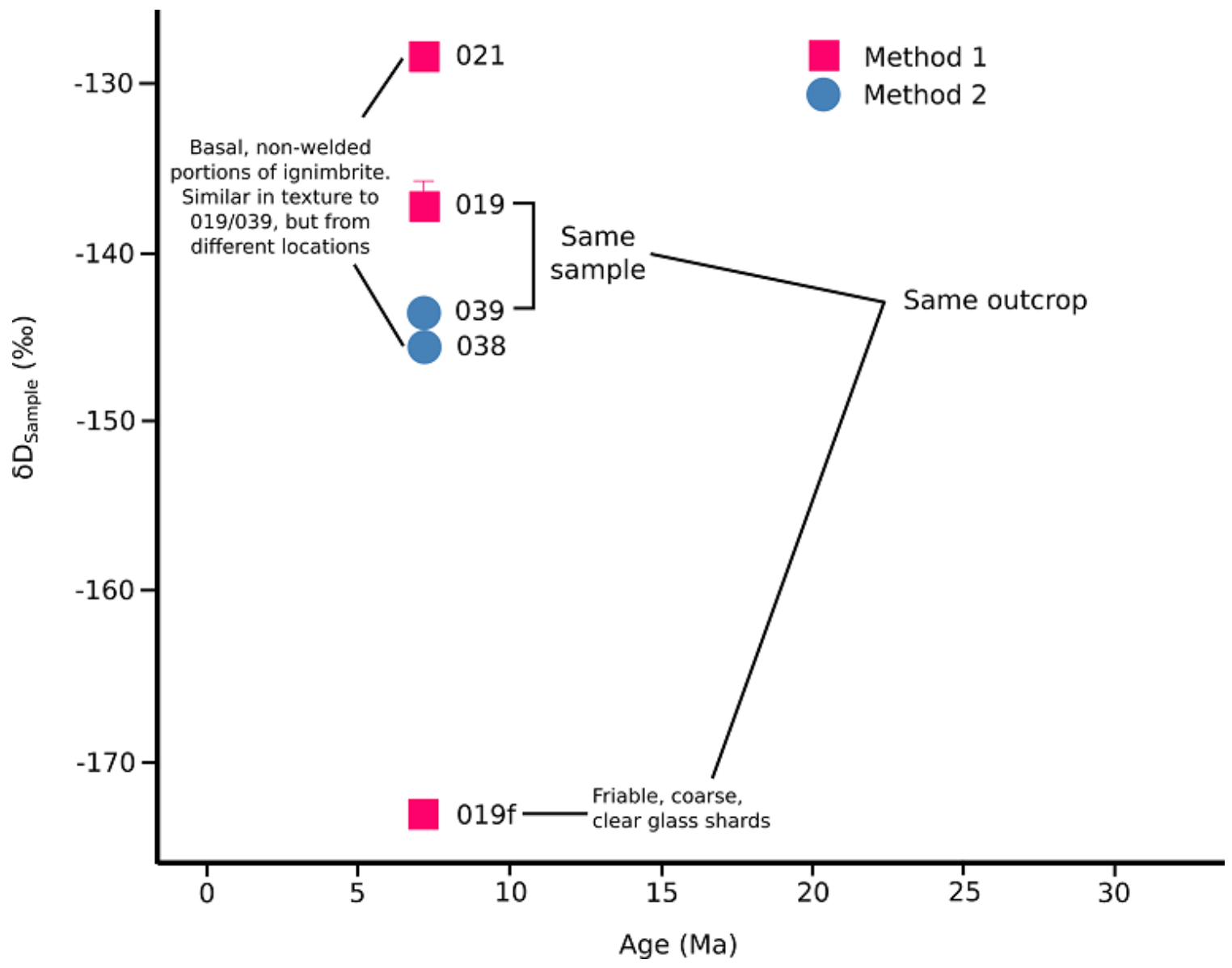

Figure 5-1. A plot of all Rattlesnake $\delta D$ values. Pink squares are Method 1 and blue circles are Method 2. Samples 019, 039 and 019f were all collected from the same outcrop. Sample 019f is unique due to being composed of very friable, large grained clear-white glass shards, which has been interpreted as precursory ash-fall (Streck and Grunder, 1997). Samples 019, 038, 021 and 039 are all from the non-welded ignimbrite base and were similar in texture and outcrop characteristics. Samples 021 and 038 are from different locations.

\subsection{Evidence of Paleoenvironmental Water in Volcanic Glass}

\subsubsection{Samples from the Same Location of Different Age}


If volcanic glass readily re-equilibrated with modern meteoric waters, glass samples exposed to similar modern water should have indistinguishable $\delta \mathrm{D}$ values, regardless of age. Samples prepared using Method 2 show $\delta \mathrm{D}$ values across space and time that are consistent with preservation of original meteoric hydration waters.

Two sample sets of different ages collected within 3 kilometers of one another are exposed to similar modern water yet show divergent $\delta \mathrm{D}$ values. I collected sample M2-CVG038 from the $\sim 7$ Ma Rattlesnake Tuff where it overlies the Mascall Formation. Two samples from the Mascall Formation below, M2-CVG034 and M2-CVG035, had $\delta$ D values within 2.5\%o of each other (-165.6\%o and $163.3 \%$ ). However, the nearby Rattlesnake Tuff yielded a $\delta \mathrm{D}$ value of $145.5 \%$, a difference of almost $20 \%$. All three ash samples are non-welded so are similarly susceptible to re-hydration by modern water. This supports the interpretation that these sample results reflect paleo-environmental water $\delta \mathrm{D}$ at the time of deposition.

\subsubsection{Samples from Different Locations of the Same Age}

In some cases, samples from the same formation were collected in multiple, distant localities ( $>50 \mathrm{~km}$ ). Samples analyzed using Method 1 (e.g. Rattlesnake, Devine Canyon) showed ranges $>3 \%$ between spatially diverse outcrops of the same unit (Table 4-1). Conversely, samples from different outcrops of the same unit prepared using Method 2 (e.g. Deschutes, Rattlesnake) showed $<2-3 \% 0$ differences. This observation suggests that Method 2 leads to more reproducible $\delta \mathrm{D}$ values that better reflect paleowater at the time of deposition. Rattlesnake Tuff 
samples exemplify this with $\sim 9 \%$ variation within similarly textured, non-welded samples from two different localities ( $20 \mathrm{~km}$ apart) using Method 1 (M1-CVG021 and M1-CVG019) (Figure 5-1). Conversely, two Rattlesnake samples from $\sim 50 \mathrm{~km}$ apart prepared using Method 2 (M2-CVG038 and M2-CVG039) only show a 2\%o discrepancy (Figure 5-1).

\subsubsection{Preservation of a Lacustrine Signal in Volcanic Glass}

Devine Canyon Tuff samples were collected above a tabular diatomite bed indicative of a lacustrine depositional environment. Lakes may exhibit significantly heavier isotopic compositions ( $>100 \%$ oD) compared to nearby fluvial settings, particularly in closed basins where evaporation can be significant (Gonfiantini, 1986; Talbot, 1990). For this lacustrine sample (M2-CVG040), Method 2 results were $32 \%$ more positive than the same sample prepared using Method 1. This suggests that $\mathrm{HF}$ abrasion is removing surface precipitates that have re-equilibrated with modern water, leaving behind the original, evaporatively enriched lacustrine signal. Though this sample was not $\geq 99 \%$ pure, low intra-replicate variability $(<2 \% 0)$ suggests that the difference is not likely due to mineral grain contamination.

\subsection{Recommendations for Sample Selection and Preparation}

Data in this study suggest that $\delta \mathrm{D}$ ratios may vary significantly within different textural and/or compositional zones of a tuff as well as spatially distinct outcrop localities of the same tuff due to variation in hydration and corrosion of 
volcanic glass shards. However, my results suggest that accurate paleowater signals can be derived through strict glass shard selection (70-150 $\mu \mathrm{m})$ and HF treatment (Method 2) to effectively remove surface contaminants and isolate isotropic, homogeneously hydrated shards (Appendix C). When sampling in the field, it is not always clear which tuff units and how much sample will produce a sufficient amount of $\geq 99 \%$ pure glass. Therefore, I recommend collecting and crushing relatively large volumes $(1+\mathrm{kg})$ of samples from many units, including sub-samples of different textures within each unit when possible. This allows for a determination of variability within units to help identify which $\delta \mathrm{D}$ values are most reliable for paleoenvironmental reconstruction. The low intra-replicate variability observed in the heavily altered Tuff of Foster Dam sample suggests that reproducible data is not an adequate indicator of glass purity (Table 4-1). Additional opportunities for future research are discussed in Appendix F.

\subsection{Paleoenvironmental Implications}

Converting glass $\delta \mathrm{D}$ values to meteoric water using Equation 1, Method $2 \delta \mathrm{D}$ values of paleowaters in the lee of the Cascades in Oregon are negative (Avg. =$122.9 \%$ of $\geq 99 \%$ pure samples) relative to modern, non-evaporated meteoric water (Avg. $=-104 \%$ ). If the Cascades have been continuously increasing in surface elevation since the Oligocene, driving progressive isotopic depletion due to the altitude effect (Rozanski et al., 1993; Poage and Chamberlain, 2001), one might expect modern meteoric water $\delta \mathrm{D}$ values to be more negative than paleowater 
samples, similar to trends seen in carbonate $\delta^{18} 0$ proxies (Kohn et al., 2002; Kohn, 2003; Takeuchi et al., 2010). In contrast, my results show more negative $\delta \mathrm{D}$ values of paleowater in the past. This could be explained by higher aridity and evaporative enrichment of surface waters in a more developed Cascade rainshadow, as interpreted in the lee of mountain ranges elsewhere (Kent-Corson et al., 2009; Bershaw et al., 2012; Caves et al., 2015; Saylor et al., 2009).

That said, my volcanic glass results show a large range in values (-165 to $130 \% 0 \delta \mathrm{D})$ and lack a significant trend with time $\left(\mathrm{R}^{2}<0.1\right)$. This variation could be due to relatively short-term $(<100 \mathrm{ka})$ fluctuations in climate unrelated to topographic changes as volcanic glass only takes hundreds to thousands of years to fully hydrate (Seligman et al., 2016; Martin et al., 2017; Cassel and Breecker, 2017; Friedman and Long, 1976). It is necessary to increase temporal resolution if relatively short timescale climate fluctuations are influencing $\delta \mathrm{D}$ values. This could enable the determination of which $\delta \mathrm{D}$ values are the result of shorter-scale climatic "noise" versus long-term (>1 Ma) climatic and tectonic evolution. 


\section{CONCLUSIONS}

The work presented in this study highlights the importance of strict preparation protocol with HF abrasion and heavy liquid separation to remove mineral and surface contaminants and isolate a specific grain size fraction (Method 2). This decreased intra-replicate variability of both water content and $\delta \mathrm{D}$ value for samples prepared using both methods. Improper grain size fraction may be to blame for previous work that suggests HF abrasion increases variability.

All samples $\geq 99 \%$ purity prepared using Method 2 protocol exhibited a decrease in $\delta \mathrm{D}$ of various magnitude $(\sim 2.5-10 \%)$ relative to samples prepared with Method 1. This shift is away from modern water values, but still within the wide range of published modern meteoric water values in central Oregon. This suggests that Method 2 sample preparation gives results that more accurately reflect paleowater values.

My results indicate that volcanic glass does preserve paleowater $\delta \mathrm{D}$ values, as contemporaneous samples from different localities have similar $\delta \mathrm{D}$ values (range of $<3 \%$ ), while different aged samples from the same locality yield very distinct $\delta \mathrm{D}$ values (20\%o difference). That said, magmatic water can influence the isotopic composition in large grains $(>150 \mu \mathrm{m})$ and where wt. \% water is low $(<1.5 \mathrm{wt}$. \%). I conclude that past studies suggesting re-equilibration of samples with modern water were likely measuring $\delta \mathrm{D}$ from water contained within surface contaminants, which we effectively remove with preparation Method 2. 
Overall, volcanic glass has great potential as a paleoenvironmental proxy, but requires better understanding of water-glass interaction, from original magmatic water to secondary hydration for robust paleoenvironmental interpretations.

Future work should focus on the impact of magmatic waters on the overall isotopic composition as well as variations in the fractionation of liquid water into volcanic glass and associated minerals based on composition, texture, and water content. 


\section{REFERENCES}

Anovitz, L.M., Cole, D.R., and Riciputi, L.R., 2009, Low-temperature isotopic exchange in obsidian: Implications for diffusive mechanisms: Geochimica et Cosmochimica Acta, v. 73, p. 3795-3806, doi: 10.1016/j.gca.2009.02.035.

Bershaw, J., Garzione, C.N., Higgins, P., MacFadden, B.J., Anaya, F., and Alvarenga, H., 2010, Spatial-temporal changes in Andean plateau climate and elevation from stable isotopes of mammal teeth: Earth and Planetary Science Letters, v. 289, p. 530-538, doi: 10.1016/j.epsl.2009.11.047.

Bershaw, J., Garzione, C.N., Schoenbohm, L., Gehrels, G., and Tao, L., 2012, Cenozoic evolution of the Pamir plateau based on stratigraphy, zircon provenance, and stable isotopes of foreland basin sediments at Oytag (Wuyitake) in the Tarim Basin (west China): Journal of Asian Earth Sciences, v. 44, p. 136-148, doi: 10.1016/j.jseaes.2011.04.020.

Bestland, E.A., Forbes, M.S., Krull, E.S., Retallack, G.J., and Fremd, T., 2008, Stratigraphy, paleopedology, and geochemistry of the middle Miocene Mascall Formation (type area, central Oregon, USA): PaleoBios, v. 28, p. 41-61.

Bestland, E.A., Retallack, G.J., and Swisher III, C.C., 1997, Stepwise Climate Change Recorded in Eocene-Oligocene Paleosol Sequences From Central Oregon: The Journal of Geology, v. 105, p. 153-172, doi: 10.1086/515906.

du Bray, E., and John, D.A., 2011, Petrologic, tectonic, and metallogenic evolution of the Ancestral Cascades magmatic arc, Washington, Oregon, and northern California: Geosphere, v. 7, p. 1102-1133, doi: 10.1130/GES00669.1.

Brown, E.A., 2017, Rhyolite Petrogenesis at Tower Mountain Caldera, OR: Portland State University.

Cailleteau, C., Angeli, F., Devreux, F., Gin, S., Jestin, J., Jollivet, P., and Spalla, O., 2008, Insight into silicate-glass corrosion mechanisms.: Nature materials, v. 7, p. 978-983, doi: 10.1038/nmat2301.

Canavan, R.R., Carrapa, B., Clementz, M.T., Quade, J., DeCelles, P.G., and Schoenbohm, L.M., 2014, Early cenozoic uplift of the Puna plateau, central andes, based on stable isotope paleoaltimetry of hydrated volcanic glass: Geology, v. 42, p. 447-450, doi: 10.1130/G35239.1.

Casey, W.H., 2008, Glass and mineral corrosion: Dynamics and durability: Nature materials, v. 7, p. 930-932, doi: 10.1103/RevModPhys.81.943.

Cassel, E.J., and Breecker, D.O., 2017, Long-term stability of hydrogen isotope ratios in hydrated volcanic glass: Geochimica et Cosmochimica Acta, v. 200, p. 67-86, doi: 10.1016/j.gca.2016.12.001.

Cassel, E.J., Breecker, D.O., Henry, C.D., Larson, T.E., and Stockli, D.F., 2014, Profile of a paleo-orogen: High topography across the present-day Basin and Range from 40 
to 23 Ma: Geology, v. 42, p. 1007-1010, doi: 10.1130/G35924.1.

Cassel, E.J., Graham, S.A., and Chamberlain, C.P., 2009, Cenozoic tectonic and topographic evolution of the northern Sierra Nevada, California, through stable isotope paleoaltimetry in volcanic glass: Geology, v. 37, p. 547-550, doi: 10.1130/G25572A.1.

Caves, J.K., Winnick, M.J., Graham, S.A., Sjostrom, D.J., Mulch, A., and Chamberlain, C.P., 2015, Role of the westerlies in Central Asia climate over the Cenozoic: Earth and Planetary Science Letters, v. 428, p. 33-43, doi: 10.1016/j.eps1.2015.07.023.

Chamberlain, C.P., Mix, H.T., Mulch, A., Hren, M.T., Kent-Corson, M.L., Davis, S.J., Horton, T.W., and Graham, S.A., 2012, The Cenozoic climatic and topographic evolution of the western North American Cordillera: American Journal of Science, v. 312, p. 213-262, doi: 10.2475/02.2012.05.

Clog, M., Aubaud, C., Cartigny, P., and Dosso, L., 2013, The hydrogen isotopic composition and water content of southern Pacific MORB: A reassessment of the $\mathrm{D} / \mathrm{H}$ ratio of the depleted mantle reservoir: Earth and Planetary Science Letters, v. 381, p. 156-165, doi: 10.1016/j.eps1.2013.08.043.

Conrey, R.M., Taylor, E.M., Donnelly-Nolan, J.M., and Sherrod, D.R., 2002, NorthCentral Oregon Cascades: Exploring Petrologic and Tectonic Intimacy in a Propagating Intra-Arc Rift: Field Guide to Geologic Processes in Cascadia: Oregon Department of Geology and Mineral Industries, v. 36, p. 47-90.

Coplen, T.B., and Kendall, C., 2000, Stable Hydrogen and Oxygen Isotope Ratios for Selected Sites of the U.S. Geological Survey's NASQAN and Benchmark Surfacewater Networks: USGS Open-File Report, v. 00-160.

Dettinger, M.P., and Quade, J., 2015, Testing the analytical protocols and calibration of volcanic glass for the reconstruction of hydrogen isotopes in paleoprecipitation: Geological Society of America Memoirs , v. 212, p. 261-276, doi: $10.1130 / 2015.1212(14)$.

Dill, T.E., 1988, Stratigraphy of the Neogene volcanic rocks along the lower Metolius River, Jefferson County, Central Oregon: Oregon State University.

Fan, M., Heller, P., Allen, S.D., and Hough, B.G., 2014, Middle Cenozoic uplift and concomitant drying in the central Rocky Mountains and adjacent Great Plains: Geology, v. 42, p. 547-550, doi: 10.1130/G35444.1.

Ferns, M.L., Madin, I.P., and Taubeneck, W.H., 2001, Reconnaissance Geologic Map of the La Grande 30' x 60' quadrangle, Baker, Grant, Umatilla, and Union Counties, Oregon.:

Fiebelkorn, R.B., Walker, G.W., Macleod, N.S., Mckee, E.H., and Smith, J.G., 1982, Index to K-Ar Age Determinations for the State of Oregon.:

Fisher, 1966, Geology of a Miocene ignimbrite layer: John Day Formation, eastern 
Oregon: University of California Press.

Fisher, R. V, and Schmincke, H.-U., 1984, Pyroclastic Rocks:

Fournier, M., Gin, S., and Frugier, P., 2014, Resumption of nuclear glass alteration: State of the art: Journal of Nuclear Materials, v. 448, p. 348-363, doi: 10.1016/j.jnucmat.2014.02.022.

Friedman, I., 2000, Data-base of surface and ground water samples analyzed for deuterium and oxygen-18 from the western states of Arizona, California, Colorado, Idaho, Montana, Nevada, New Mexico, Oregon, Utah, Washington, and Wyoming.:

Friedman, I., Gleason, J., Sheppard, R., and Gude, A., 1993, Deuterium Fractionation as Water Diffuses into Silicic Volcanic Ash: Climate Change in Continental Isotopic Records, p. 321-323.

Friedman, I., Gleason, J., Wilcox, R., and Warden, A., 1993, Modeling of ancient climate from deuterium content of water in volcanic glass: Quaternary International, v. 1314, p. 201-203, doi: 10.1016/1040-6182(92)90029-2.

Friedman, I., and Long, W., 1976, Hydration rate of obsidian: Science, v. 191, p. 347352, doi: $10.1126 /$ science.191.4225.347.

Friedman, I., Smith, G.I., Johnson, C.A., and Moscati, R.J., 2002, Stable isotope compositions of waters in the Great Basin, United States 2. Modern precipitation: Journal of Geophysical Research Atmospheres, v. 107, p. 1-22, doi: 10.1029/2001JD000566.

Garzione, C.N., Quade, J., DeCelles, P.G., and English, N.B., 2000, Predicting paleoelevation of Tibet and the Himalaya from d $18 \mathrm{O}$ versus altitude gradients in meteoric water across the Nepal Himalaya: Earth and Planetary Science Letters, v. 185, p. 215-229, doi: 10.1016/S0012-821X(00)00252-1.

Giachetti, T., and Gonnermann, H.M., 2013, Water in volcanic pyroclast: Rehydration or incomplete degassing? Earth and Planetary Science Letters, v. 369-370, p. 317-332, doi: 10.1016/j.epsl.2013.03.041.

Giachetti, T., Gonnermann, H.M., Gardner, J.E., Shea, T., and Gouldstone, A., 2015, Discriminating secondary from magmatic water in rhyolitic matrix-glass of volcanic pyroclasts using thermogravimetric analysis: Geochimica et Cosmochimica Acta, v. 148, p. 457-476, doi: 10.1016/j.gca.2014.10.017.

Gin, S., Jollivet, P., Fournier, M., Angeli, F., Frugier, P., and Charpentier, T., 2015, Origin and consequences of silicate glass passivation by surface layers: Nature Communications, v. 6, p. 6360, doi: 10.1038/ncomms7360.

Gin, S., Ryan, J. V., Schreiber, D.K., Neeway, J., and Cabié, M., 2013, Contribution of atom-probe tomography to a better understanding of glass alteration mechanisms: Application to a nuclear glass specimen altered 25 years in a granitic environment: Chemical Geology, v. 349-350, p. 99-109, doi: 10.1016/j.chemgeo.2013.04.001. 
Gonfiantini, R., 1986, Environmental isotopes in lake studies, in Handbook of environmental isotope geochemistry, p. 113-168.

Gong, B., Zheng, Y.-F., and Chen, R.-X., 2007, An online method combining a thermal conversion elemental analyzer with isotope ratio mass spectrometry for the determination of hydrogen isotope composition and water concentration in geological samples: Rapid communications in mass spectrometry: RCM, v. 21, p. 1386-1392, doi: 10.1002/rcm.

Greene, R.C., 1973, Petrology of the Welded Tuff of Devine Canyon, Southeastern Oregon: USGS Professional Paper, v. 797.

Gripp, A.E., and Gordon, R.G., 2002, Young tracks of hotspots and current plate velocities: Geophysical Journal International, v. 150, p. 321-361, doi: 10.1046/j.1365-246X.2002.01627.x.

Hammond, P.E., 1979, A tectonic model for evolution of the Cascade Range: Cenozoic Paleogeography of the Western United States: Los Angeles, Pacific Section, Society of Economic Paleontologists and Mineralogists, Pacific Coast Paleogeography Symposium, p. 219-237.

Harford, C.L., and Sparks, R.S.J., 2001, Recent remobilisation of shallow-level intrusions on Montserrat revealed by hydrogen isotope composition of amphiboles: Earth and Planetary Science Letters, v. 185, p. 285-297, doi: 10.1016/S0012-821X(00)003733.

Hayes, G.P., Wald, D.J., and Johnson, R.L., 2012, Slab1.0: A three-dimensional model of global subduction zone geometry: Journal of Geophysical Research: Solid Earth, v. 117.

IAEA Global Network for Isotopes in Precipitation (GNIP) and Global Network for Isotopes in Rivers (GNIR):

IAEA GNIR - Global Network for Isotopes in Rivers:

Ingebrisen, S.E., Mariner, R.H., Cassidy, D.E., Shepherd, L.D., Presser, T.S., Pringle, M.K.W., and White, L.D., 1988, Heat-flow and water-chemistry data from the Cascade Range and adjacent areas in North-Central Oregon:

John, D.A., du Bray, E.A., Blakely, R.J., Fleck, R.J., Vikre, P.G., Box, S.E., and Moring, B.C., 2012, Miocene magmatism in the Bodie Hills volcanic field, California and Nevada: A long-lived eruptive center in the southern segment of the ancestral Cascades arc: Geosphere, v. 8, p. 44-97, doi: 10.1130/GES00674.1.

Jordan, B.T., Grunder, A.L., Duncan, R.A., and Deino, A.L., 2004, Geochronology of age-progressive volcanism of the Oregon High Lava Plains: Implications for the plume interpretation of Yellowstone: Journal of Geophysical Research B: Solid Earth, v. 109, p. 1-19, doi: 10.1029/2003JB002776.

Keating, G.N., 2005, The role of water in cooling ignimbrites: Journal of Volcanology 
and Geothermal Research, v. 142, p. 145-171, doi:

10.1016/j.jvolgeores.2004.10.019.

Kent, A.J.R., 2008, Melt Inclusions in Basaltic and Related Volcanic Rocks: Reviews in Mineralogy and Geochemistry, v. 69, p. 273-331, doi: 10.2138/rmg.2008.69.8.

Kent-Corson, M.L., Ritts, B.D., Zhuang, G., Bovet, P.M., Graham, S.A., and Page Chamberlain, C., 2009, Stable isotopic constraints on the tectonic, topographic, and climatic evolution of the northern margin of the Tibetan Plateau: Earth and Planetary Science Letters, v. 282, p. 158-166, doi: 10.1016/j.epsl.2009.03.011.

Kohn, M.J., 2003, Stable Isotope Compositions of Biological Apatite Thure E . Cerling: Reviews in Mineralogy, v. 4, p. 455-488.

Kohn, M.J., and Law, J.M., 2006, Stable isotope chemistry of fossil bone as a new paleoclimate indicator: Geochimica et Cosmochimica Acta, v. 70, p. 931-946, doi: 10.1016/j.gca.2005.10.023.

Kohn, M.J., Miselis, J.L., and Fremd, T.J., 2002, Oxygen isotope evidence for preogressive uplift of the Cascade Range, Oregon: Earth \& Planetary Science Letters, v. 204, p. 151-165, doi: 10.1016/S0012-821X(02)00961-5.

Kyser, T.K., and O'Neil, J.R., 1982, Hydrogen isotope systematics of submarine basalts [abs.]: Geological Society of America Abstracts with Programs, v. v. 14, p. 538, doi: 10.1016/0016-7037(84)90392-2.

Loewen, M.W., and Bindeman, I.N., 2015, Oxygen isotope and trace element evidence for three-stage petrogenesis of the youngest episode (260-79 ka) of Yellowstone rhyolitic volcanism: Contributions to Mineralogy and Petrology, v. 170, p. 1-25, doi: 10.1007/s00410-015-1189-5.

Martin, E., Bindeman, I., Balan, E., Palandri, J., Seligman, A., and Villemant, B., 2017, Hydrogen isotope determination by TC/EA technique in application to volcanic glass as a window into secondary hydration: Journal of Volcanology and Geothermal Research, doi: 10.1016/j.jvolgeores.2017.10.013.

McClaughry, J.D., Ferns, M.L., Gordon, C.L., and Patridge, K.A., 2009, Field trip guide to the Oligocene Crooked River caldera: Central Oregon's Supervolcano, Crook, Deschutes, and Jefferson Counties, Oregon: Oregon Geology, v. 69, p. 25-44.

McClaughry, J.D., Ferns, M.L., Streck, M.J., Patridge, K.A., and Gordon, C.L., 2009, Paleogene calderas of central and easter Oregon: Eruptive sources of widespread tuffs in the John Day and Clarno Formations: The Geological Society of America Field Guide, v. 15, p. 165-185, doi: 10.1130/2009.fl.

McClaughry, J.D., Niewendorp, C.A., Herinckx, H.H., and Duda, C.J.M., 2016, Geologic map of the Wolf Run and northern part of the Friend 7.5' quadrangles, Wasco County, Oregon scale 1:24,000: Oregon Department of Geology and Mineral Industries Geological Map Series GMS, v. XXX, p. XX. 
McClaughry, J.D., Wiley, T.J., Ferns, M.L., and Madin, I.P., 2010, Digital geologic map of the southern Willamette Valley, Benton, Lane, Linn, Marion, and Polk counties, Oregon.:

Mooney, W.D., and Weaver, C.S., 1989, Regional crustal structure and tectonics of the Pacific Coastal States; California, Oregon, and Washington: Geological Society of America Memoirs, v. 172, p. 129-162, doi: 10.1190/1.1892551.

Moore, G., 2008, Interpreting $\mathrm{H} 2 \mathrm{O}$ and $\mathrm{CO} 2$ Contents in Melt Inclusions: Constraints from Solubility Experiments and Modeling: Reviews in Mineralogy and Geochemistry, v. 69, p. 333-362, doi: 10.2138/rmg.2008.69.9.

Mulch, A., Sarna-Wojcicki, A.M., Perkins, M.E., and Chamberlain, C.P., 2008, A Miocene to Pleistocene climate and elevation record of the Sierra Nevada (California).: Proceedings of the National Academy of Sciences of the United States of America, v. 105, p. 6819-6824, doi: 10.1073/pnas.0708811105.

Nolan, G.S., and Bindeman, I.N., 2013, Experimental investigation of rates and mechanisms of isotope exchange $(\mathrm{o}, \mathrm{h})$ between volcanic ash and isotopicallylabeled water: Geochimica et Cosmochimica Acta, v. 111, p. 5-27, doi: 10.1016/j.gca.2013.01.020.

Peterson, N. V, and Groh, E.A., 1970, Geologic tour of Cove Palisades State Park near Madras, Oregon: Oregon Department of Geology and Mineral Industries, v. 32, p. $141-168$.

Pingel, H., Alonso, R.N., Mulch, A., Rohrmann, A., Sudo, M., and Strecker, M.R., 2014, Pliocene orographic barrier uplift in the southern Central Andes: Geology, v. 42, p. 691-694, doi: 10.1130/G35538.1.

Pitcher, B.W., Kent, A.J.R., Grunder, A.L., and Duncan, R.A., 2017, Frequency and volumes of ignimbrite eruptions following the Late Neogene initiation of the Central Oregon High Cascades: Journal of Volcanology and Geothermal Research, v. 339, p. 1-22, doi: 10.1016/j.jvolgeores.2017.04.019.

Poage, M.A., and Chamberlain, C.P., 2001, Empirical relationships between elevation and the stable isotope composition of precipitation and surface waters: Considerations for studies of paleoelevation change: American Journal of Science, v. 301, p. 1-15, doi: 10.2475/ajs.301.1.1.

Priest, G.R., 1990, Volcanic and Tectonic Evolution of the Cascade Volcanic Arc, Central Oregon: Journal of Geophysical Research, v. 95, p. 19583-19599.

Qi, H., Coplen, T.B., Olack, G.A., and Vennemann, T.W., 2014, Caution on the use of NBS 30 biotite for hydrogen-isotope measurements with on-line high-temperature conversion systems: Rapid Communications in Mass Spectrometry, v. 28, p. 19871994, doi: 10.1002/rcm.6983.

Retallack, G.J., Tanaka, S., and Tate, T., 2002, Late Miocene advent of tall grassland 
paleosols in Oregon: Palaeogeography, Palaeoclimatology, Palaeoecology, v. 183, p. 329-354, doi: 10.1016/S0031-0182(02)00250-X.

Robinson, P.T., Brem, G.F., and Mckee, E.H., 1984, John Day Formation of Oregon : A distal record of early Cascade volcanism: Geology, v. 12, p. 229-232, doi: 10.1130/0091-7613(1984)12<229.

Rohrmann, A., Sachse, D., Mulch, A., Pingel, H., Tofelde, S., Alonso, R.N., and Strecker, M.R., 2016, Miocene orographic uplift forces rapid hydrological change in the southern central Andes: Nature Publishing Group, p. 1-7, doi: $10.1038 /$ srep35678.

Rowley, D.B., 2007, Stable Isotope-Based Paleoaltimetry: Theory and Validation: Reviews in Mineralogy and Geochemistry, v. 66, p. 23-52, doi: 10.2138/rmg.2007.66.2.

Rozanski, K., Araguas-Araguas, L., and Gonfiantini, R., 1993, Rozanski_1993_IsotopicPatternsModernPrecip_GPM.pdf: American Geophysical Union,.

Sarna-Wojcicki, A.M., 1984, Chemical analyses, correlations, and ages of upper Pliocene and Pleistocene ash layers of east-central and southern California:

Savoie, B.Y., 2013, Arsenic Mobility and Compositional Variability in High-Silica Ash Flow Tuffs: Portland State University.

Saylor, J.E., Quade, J., Dettman, D.L., DeCelles, P.G., Kapp, P.A., and Ding, L., 2009, The late Miocene through present paleoelevation history of southwestern Tibet: American Journal of Science, v. 309, p. 1-42, doi: 10.2475/01.2009.01.

Schiano, P., 2003, Primitive mantle magmas recorded as silicate melt inclusions in igneous minerals: Earth-Science Reviews, v. 63, p. 121-144, doi: 10.1016/S00128252(03)00034-5.

Schlinger, C.M., Rosenbaum, J.G., and Veblen, D.R., 1988, Fe-oxide microcrystals in welded tuff from southern Nevada; origin of remanence carriers by precipitation in volcanic glass: Geology, v. 16, p. 556-559.

Schmandt, B., Humphreys, E., Schmandt, B., and Humphreys, E., 2011, Seismically imaged relict slab from the 55 Ma Siletzia accretion to the northwest United States: doi: 10.1130/G31558.1.

Seligman, A.N., Bindeman, I.N., Watkins, J.M., and Ross, A.M., 2016, Water in volcanic glass: From volcanic degassing to secondary hydration: Geochimica et Cosmochimica Acta, v. 191, p. 216-238, doi: 10.1016/j.gca.2016.07.010.

Sheppard, R., and Gude, A., 1968, Distribution and genesis of authigenic silicate minerals in tuffs of Pleistocene Lake Tecopa, Inyo County, California: US Govt. Print office, 
Sherrod, D.R., and Smith, J.G., 2000, Geologic map of upper Eocene to Holocene volcanic and related rocks of the Cascade Range, Oregon.:

Smith, G.A., 1985, Stratigraphy, sedimentology, and petrology Neogene rocks in the Deschutes Basin, Central Oregon: A record of continental-margin volcanism and its influence on fluvial sedimentation in an Arc-Adjacent Basin.: Thesis, p. 1-467.

Smith, M.E., Cassel, E.J., Jicha, B.R., Singer, B.S., and Canada, A.S., 2017, Hinterland drainage closure and lake formation in response to middle Eocene Farallon slab removal, Nevada, U . S . A .: Earth and Planetary Science Letters, v. 479, p. 156169, doi: 10.1016/j.epsl.2017.09.023.

Smith, G.A., Snee, L.W., and Taylor, E.M., 1987, Stratigraphic, sedimentologic, and petrologic record of the late Miocene subsidence of the central Oregon High Cascades: Geology, v. 15, p. 389-392.

Stauffer, E.A., and Cassel, E.J., 2017, Glass-water hydrogen isotope fractionation in recent volcanic glass:

Streck, M., and Ferns, M.L., 2004, The Rattlesnake Tuff and other Miocene silicic volcanism in eastern Oregon: U.S.Geological Survey Open-File Report, v. 1222, p. 4-19.

Streck, M.J., and Grunder, a L., 1997, Compositional gradients and gaps in high-silica rhyolites of the Rattlesnake Tuff, Oregon: Journal of Petrology, v. 38, p. 133-163, doi: 10.1093/petrology/38.1.133.

Streck, M.J., and Grunder, A.L., 1995, Crystallization and welding variations in a widespread ignimbrite sheet ; the Rattlesnake Tuff, eastern Oregon , USA: , p. 151169.

Sundell, K.E., 2017, Cenozoic surface uplift and basin formation in the Peruvian central Andes: University of Houston.

Swisher III, C.C., 1992, 40Ar/39Ar dating and its application to the calibration of the North American Land Mammal Ages: University of California, Berkeley.

Takeuchi, A., Hren, M.T., Smith, S. V, Chamberlain, C.P., and Larson, P.B., 2010, Pedogenic carbonate carbon isotopic constraints on paleoprecipitation: Evolution of desert in the Pacific Northwest, USA, in response to topographic development of the Cascade Range: Chemical Geology, v. 277, p. 323-335, doi:

10.1016/j.chemgeo.2010.08.015.

Takeuchi, A., and Larson, P.B., 2005, Oxygen isotope evidence for the late Cenozoic development of an orographic rain shadow in eastern Washington, USA: Geology, v. 33, p. 313-316, doi: 10.1130/G21335.1.

Talbot, M.R., 1990, A review of the palaeohydrological interpretation of carbon and oxygen isotopic ratios in primary lacustrine carbonates: Chemical Geology: Isotope Geoscience section, v. 80, p. 261-279, doi: 10.1016/0168-9622(90)90009-2. 
Taylor, H.P., 1974, The application of oxygen and hyrdrogen isotope studies to problems of hydrothermal alteration and ore deposition: Economic geology, v. 69, p. 843-883.

Taylor, E.M., 1990, Volcanic history and tectonic development of the central high Cascade Range, Oregon: Journal of Geophysical Research, v. 95, p. 19611-19622.

Valle, N., Verney-Carron, A., Sterpenich, J., Libourel, G., Deloule, E., and Jollivet, P., 2010, Elemental and isotopic (29Si and 18O) tracing of glass alteration mechanisms: Geochimica et Cosmochimica Acta, v. 74, p. 3412-3431, doi: 10.1016/j.gca.2010.03.028.

Verplanck, E.P., and Duncan, R.A., 1987, Temporal variations in plate convergence and eruption rates in the Western Cascades, Oregon: Tectonics, v. 6, p. 197-209.

Wells, R.E., Blakely, R.J., Simpson, R.W., Weaver, C.S., Haugerud, R., and Wheeler, K., 2016, Tectonic plate motions, crustal blocks, and shallow earthquakes in Cascadia: USGS,

Wells, R., Bukry, D., Friedman, R., Pyle, D., Duncan, R., Haeussler, P., and Wooden, J., 2014, Geologic history of Siletzia , a large igneous province in the Oregon and Washington Coast Range : Correlation to the geomagnetic polarity time scale and implications for a long-lived Yellowstone hotspot: , p. 692-719, doi: 10.1130/GES01018.1.

Wilson, D.S., 1988, Tectonic history of the Juan de Fuca Ridge over the last 40 million years: Journal of Geophysical Research: Solid Earth, v. 93, p. 11863-11876. 


\section{APPENDICES}

\section{A - Geologic Context}

In Oregon, the modern Cascade Range is a roughly north-south trending volcanic arc resulting from the subduction of the Juan de Fuca oceanic plate beneath the North American continental plate (Hammond, 1979; Priest, 1990) (Figure A-1). Similar subduction zone systematics have existed in the area since $\sim 45-42 \mathrm{Ma}$, after the accretion of the Siletzia Terrane (Sherrod and Smith, 2000; Schmandt et al., 2011). The modern subduction zone experiences oblique $\left(\sim \mathrm{N} 61^{\circ} \mathrm{E}\right)$ convergence of $\sim 36 \mathrm{~mm} /$ year (Gripp and Gordon, 2002). Since the Juan de Fuca plate is relatively young ( $~ 8 \mathrm{Ma}$ ), warm, and buoyant (Wilson, 1988), the subducting slab is estimated to have a relatively shallow subduction angle. Mooney and Weaver (1989) estimate that the subducting slab has a $\sim 3^{\circ}$ dip within $50 \mathrm{~km}$ of the trench, steepening to $\sim 10^{\circ}$ landward, and to $25^{\circ}$ underneath the Cascade Arc. Numerical models estimate a relatively constant dip angle of $\sim 18^{\circ}$ based on seismic data, but the Cascadia subduction zone remains poorly resolved compared to more seismically active areas (Hayes et al., 2012). The modern High Cascade Arc is located approximately $300 \mathrm{~km}$ from the trench. Much of the modern High Cascades are within a graben bounded to the east and west by normal faults active sometime after $\sim 5 \mathrm{Ma}$ (Figure A-2) (Pitcher et al., 2017 and references therein). 


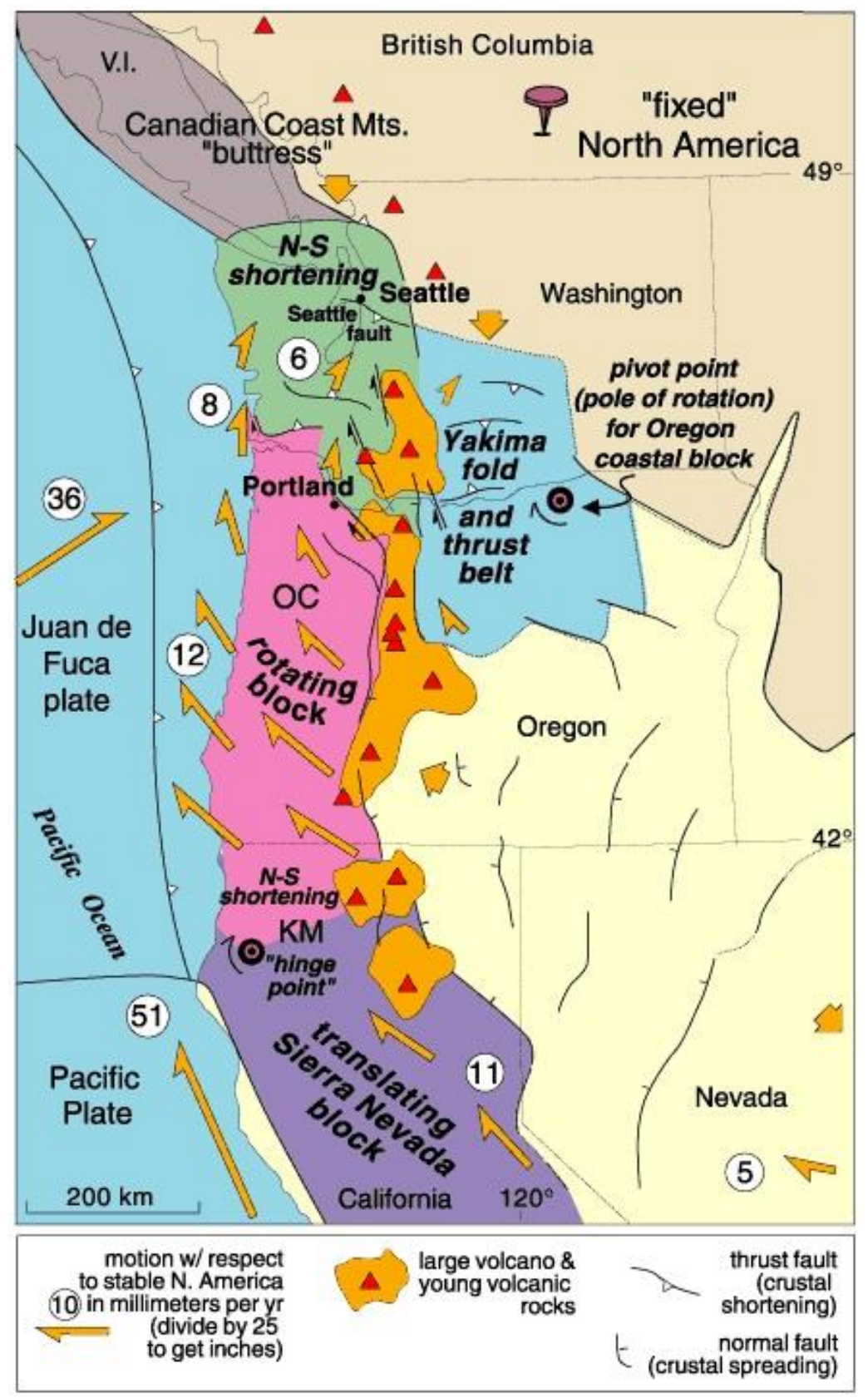

Figure A-1. Regional map showing plate motions relative to a fixed North American Plate adapted from Wells et al. (2016). 


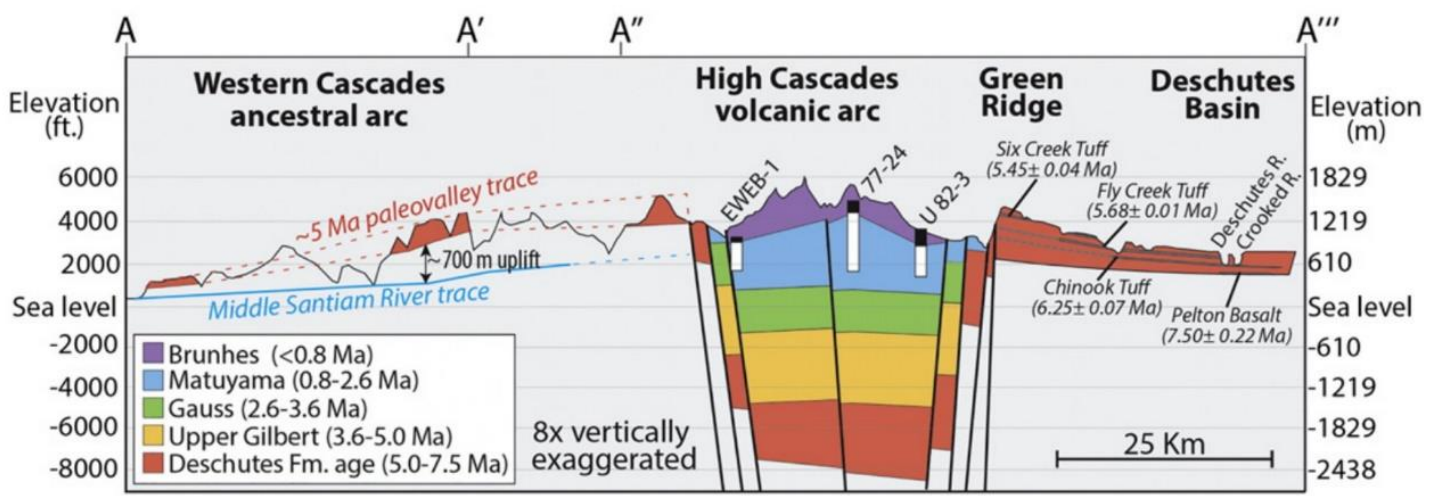

Figure A-2. Cross-section from west to east of the modern High Cascade Range between Mt. Jefferson and Three Sisters from Pitcher and others (2017) and references therein.

\section{Geologic History}

\section{Pre-Cascade geology}

Around $60 \mathrm{Ma}$, much of modern day Oregon was an ocean with the coastline roughly trending between the Klamath Mountains and the Blue Mountains. By 51 $49 \mathrm{Ma}$, the Siletzia terrane, composed of basaltic seamounts, accreted onto the coast of Oregon and Washington during a period of plate reorganization in the northeast Pacific basin. This caused the subduction zone to step west (seaward), which possibly caused extensional sill complexes that intrude the Siletzia terrane at 48-45 Ma (Wells et al., 2014). Slab rollback may have also induced the relatively shortlived Challis magmatism in an area east of the modern arc at $~ 50 \mathrm{Ma}$ (Schmandt et al., 2011)(Figure A-3)). However, others (du Bray and John, 2011 and references therein) have attributed older magmatism occurring well inland (ie: Eocene Challis, Eocene Clarno, and Oligocene John Day formations) to a shallower slab subduction angle and associate the subsequent migration of magmatism toward the continental margin to a steepening slab.

The Cascade Range in Oregon is traditionally split into two group: The High Cascades and the Western Ancestral Cascades, although the transition time between the two is poorly defined. Various studies have attempted to classify changes through time, and a summary is provided below (Priest, 1990; Hammond, 1979; John et al., 2012; du Bray and John, 2011; Taylor, 1990). 


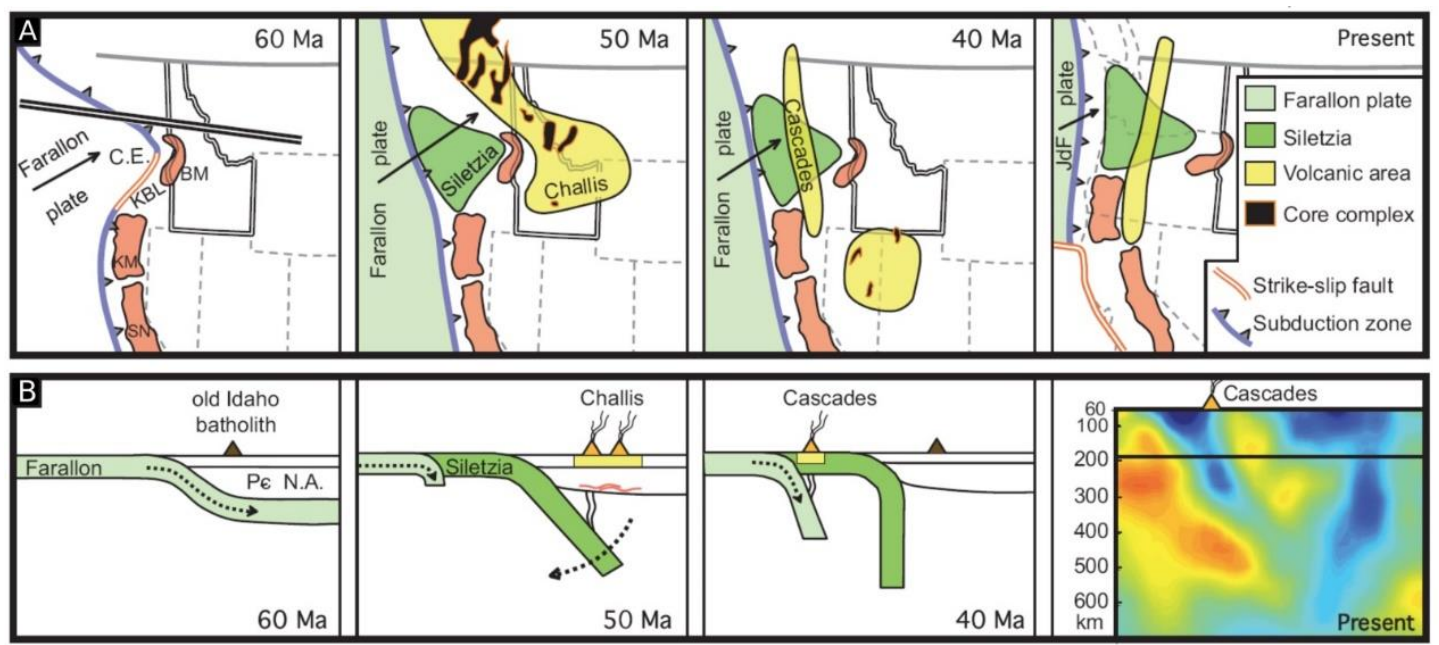

Figure A-3. A: Maps illustrating regional tectonic and magmatic evolution. Intact and coherent units defined by presence of Mesozoic to Cretaceous plutons and associated arc-related rocks are shown in pink; Klamath Mountains (KM), Blue Mountains (BM), and Sierra Nevada (SN). Prior to accretion, 60 $\mathrm{Ma}$, Klamath-Blue Mountains lineament (KBL) is shown as transform boundary. At 60 Ma Farallon plate subducted to northeast in Columbia Embayment (C.E.). Siletzia accreted and subduction stepped west ca. 55-53 Ma, and by $50 \mathrm{Ma}$ Challis magmatism was strong (JdF-Juan de Fuca). B: Cross sectional interpretation of subduction history along line in A (left) based on seismic tomography. At $60 \mathrm{Ma}$, Farallon slab subducts flat against Precambrian (Pc) North America (N.A.). Then, shortly after Siletzia accretion (50 Ma), Cascadia subduction initiates and abandoned, previously flat Farallon slab rolls back, exposing basal North America and Farallon crust to inflowing asthenosphere, causing melting (Challis magmatism). Event is over by $40 \mathrm{Ma}$, and little has changed to present, represented by tomography cross section (right) (from Schmandt et al., 2011 and references therein).

\section{Western (Ancestral) Cascades ( 45 - 7.5 Ma)}

The onset of Cascade volcanism began around $45 \mathrm{Ma}$, approximately $5 \mathrm{Ma}$ after the accretion of the Siletzia Terrane (Wells et al., 2014). Volcanism was largely concentrated in southwestern Washington, and rocks were largely basaltic to andesitic in composition (du Bray and John, 2011). The early Western Cascades Arc magmatism ( $\sim 45-40 \mathrm{Ma})$ is geochemically primitive, meaning the mantle component had undergone little fractionation or contamination from continental rocks during ascent (du Bray and John, 2011).

By $235 \mathrm{Ma}$, the entire arc was established from northern California to present-day Mount Rainier, and was 3-4 times wider than the modern day arc (Priest, 1990). Volcanism was largely tholeiitic basalt to andesite with minor dacite and rhyolite domes (du Bray and John, 2011). Ignimbrites and ash layers of the John Day Formation of eastern Oregon are evidence of explosive volcanism in the Cascades during this time (Robinson et al., 1984). The high amount of volcanism during this time coincides with high plate convergence rates (Verplanck and Duncan, 1987).

Around $26 \mathrm{Ma}$, the composition of Cascade Arc volcanism shifted toward calc-alkaline, suggesting more crustal contamination (Sherrod and Smith, 2000). Volcanism remained voluminous, but as magma evolved, andesitic lavas and dacitic 
to rhyolitic tephra became more common (du Bray and John, 2011; Sherrod and Smith, 2000). During this time, the first known plutons from Cascade Arc magmatism formed (du Bray and John, 2011). Around $17 \mathrm{Ma}$, volcanic activity slowed (Taylor, 1990).

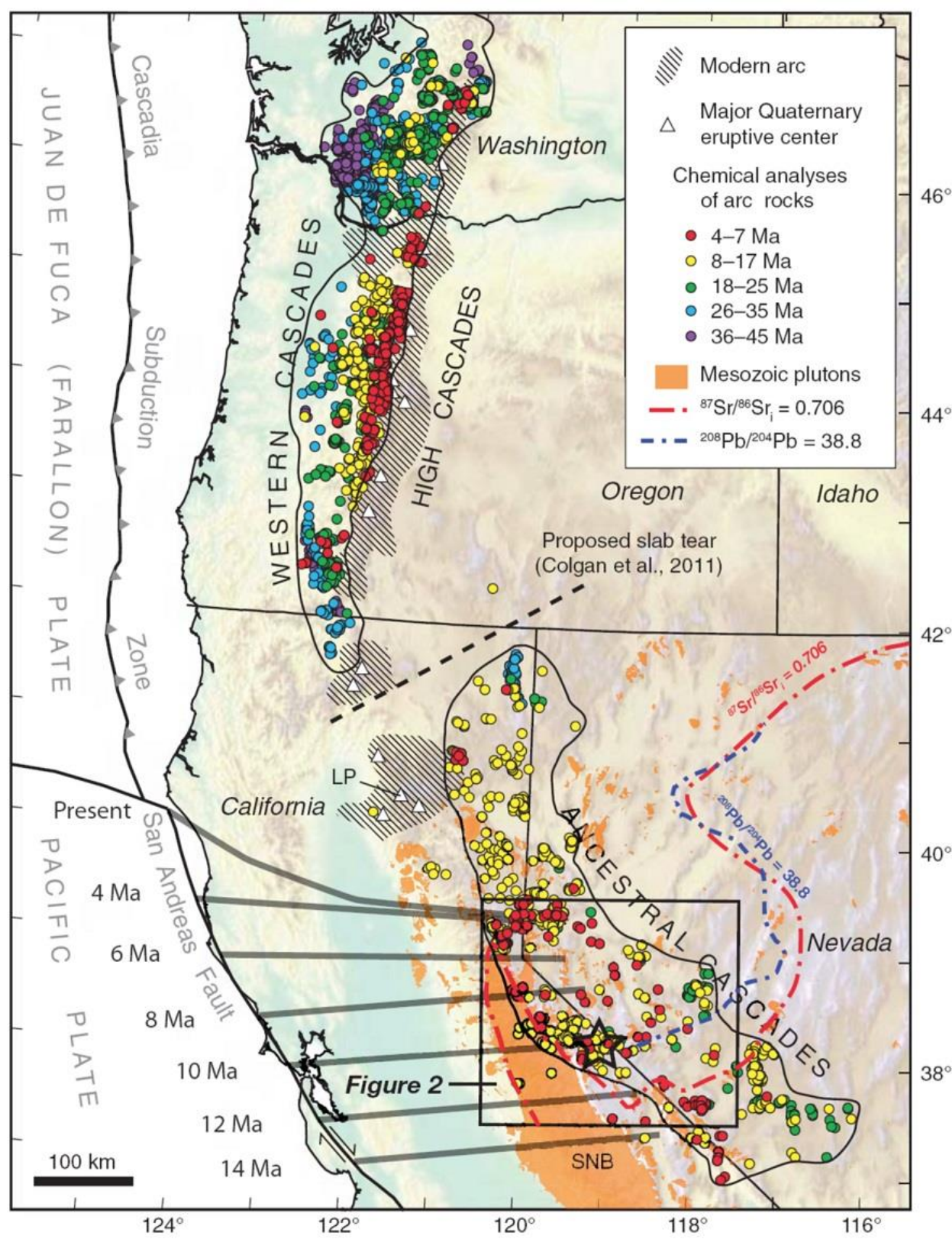

Figure A-4. Map of the western United States showing the inferred extent of ancestral and modern Cascade magmatic arcs. Heavy gray line indicates southern edge of subducting Farallon plate at specified time. White triangles indicate volcanic peaks of the modern High Cascades. Figure and caption adapted from John et al., 2012 and references therein. 
Reduced Cascade Arc volcanic activity ( $\sim 3 x$ lower) continued from $\sim 17-10$ $\mathrm{Ma}$, perhaps due to a decrease in the convergence rate between the North American Plate and Juan de Fuca Plate (Priest, 1990). During this time, the Columbia River Flood Basalts (CRBs) inundated northwest Oregon and southern Washington. The lack of interbedded volcaniclastic rocks further suggests subordinate arc volcanism (Sherrod and Smith, 2000). The only area with evidence of volcanism during this time is in northern Oregon, near modern day Mount Hood, which had been a quiescent for the preceding 20 Ma (Priest, 1990; du Bray and John, 2011). The active arc became more focused, narrowing in comparison to the early Western Cascades (Priest, 1990). Volcanism consisted of effusive andesitic eruptions, with dacite and rhyolite only found in the $15-12$ Ma Simtustus Formation in the central Oregon Deschutes Basin (Priest, 1990; du Bray and John, 2011; Smith, 1985).

\section{Modern (High) Cascades Arc ( 7.5 Ma to Modern)}

Higher rates of volcanism along a new, narrower arc axis to the east of the Ancestral Western Cascades marks the onset of High Cascade volcanism at 7.4 Ma (Priest, 1990). Arc narrowing and migration to the east (landward) could be induced by a general shallowing of the subducting slab dip through time, with steepening of the slab at depths where melt initiates (du Bray and John, 2011; Priest, 1990). Eastward migration of the arc could also be related to block rotation (Wells et al., 2014). Many of the volcanic deposits from the early High Cascades have been buried by subsequent lava flows and normal faulting, but the Deschutes Formation in central Oregon preserves a record of an 800 ka pulse of explosive volcanism (Pitcher et al., 2017; Taylor, 1990; Smith, 1985). Aggradation of these sediments in a fluvial setting continued until the formation of the High Cascades Graben at $\sim 5.3 \mathrm{Ma}$, which bounded the Arc to the east and west (Smith et al., 1987; Taylor, 1990). The onset of extensional faulting is marked by a switch to low $\mathrm{K}$ midoceanic ridge basalt type volcanism (MORB-like). Data from geothermal drill cores suggest a total subsidence of $\sim 3 \mathrm{~km}$ in the southern area between Mt. Jefferson and Three Sisters, and $\sim 1 \mathrm{~km}$ in the northern segment between Mt. Hood and Mt. Jefferson (Conrey et al., 2002). The total extension inferred from cross-sections is $<1 \mathrm{~km}$ (Priest, 1990). Around the same time, the Western Cascades were experiencing uplift, inferred from stream incision (Priest, 1990).

Compared to the early High Cascades, volcanism generally decreased after the onset of subsidence. Deposits were largely contained within the graben, and most have been subsequently buried (Taylor, 1990). Volcanism of the last $\sim 2 \mathrm{Ma}$ is characterized by basalt to basaltic-andesite shield volcanoes and more evolved stratovolcanoes (e.g. Mt. Jefferson, Mt. Washington, etc.)(Priest, 1990).

\section{Paleosol record as a proxy for paleotopography}

Paleosol evidence suggests cooling and drying in central Oregon, from a neartropical to subtropical climate after the mid-Eocene climatic optimum, between 43 
and 42.8 Ma (Bestland et al., 1997). At 34 Ma, paleosols mark the EoceneOligocene boundary with a change from subtropical soils to those formed in a temperate, humid climate. At $\sim 30 \mathrm{Ma}$, global cooling caused calcareous paleosols to form in what is interpreted as a sub-humid, temperate environment (Bestland et al., 1997). Paleosols from the Mascall Formation suggest balmy conditions during the mid-Miocene climatic optimum ( 15.5 Ma) (Bestland et al., 2008). Paleosols from the overlying Rattlesnake Formation exhibit an interpreted shift from a subhumid woodland climate at $\sim 7.5-7.3 \mathrm{Ma}$ to a semi-arid grassland climate at $\sim 7.3 \mathrm{Ma}$. The climate became similar to modern by $\sim 7.1 \mathrm{Ma}$ (Retallack et al., 2002).

\section{Isotopic evidence for paleotopography}

Although there are many numerical and conceptual models based on field measurements and geochemistry, absolute changes in height of the Cascade Arc through time are difficult to constrain. $\delta^{18} 0$ data from fossil teeth (Kohn et al., 2002) suggest a quasi-monotonic increase in elevation of the Cascade Range in Oregon since $\sim 27 \mathrm{Ma}$, with a hiatus $\sim 15.4-7.2 \mathrm{Ma}$, possibly related to the eruption of the Columbia River Basalts (CRB). A hiatus coinciding with CRB is also consistent with subordinate volcanism (Sherrod and Smith, 2000; Priest, 1990). Kohn and others' (2002) interpretation of crustal thickening and topographic uplift is consistent with simple isostatic and tectonic models of progressive uplift since the Eocene (Hammond, 1979).

That said, $\delta^{18} \mathrm{O}$ and $\delta^{13} \mathrm{C}$ data from authigenic smectites (Takeuchi and Larson, 2005) and pedogenic carbonates (Takeuchi et al., 2010) in the lee of the Cascades suggest more punctuated uplift and development of a rain shadow during the late Cenozoic ( 15 - $5 \mathrm{Ma})$. Kohn and Law (2006) interpret changes in $\delta^{18} 0$ and $\delta^{13} \mathrm{C}$ from fish bones as evidence of an approximate doubling in height of the Cascade Range since $7 \mathrm{Ma}$. This interpretation is relatively consistent with Priest (1990), which suggests significant uplift beginning during mid-Miocene to early Pliocene time. Although no absolute height estimates are mentioned, the older, early Western Cascades are interpreted to have been low elevation, based on lateral continuity of ash flow sheets. 


\section{B - Sample Descriptions}

\section{Tuff of Dale - 32.66 Ma (M1-CVG013, M2-CVG013)}

A thick unit of rhyolitic welded ash-flow tuff exposed along the North Fork of the John Day River interpreted to have erupted from the Tower Mountain Caldera (Ferns et al., 2001) and dated using ${ }^{40} \mathrm{Ar} /{ }^{39} \mathrm{Ar}$ (Brown, 2017). In hand sample it is light-gray with white pumice fragments and broken crystals of plagioclase feldspar. I took the sample from a partially welded zone (not entirely flattened pumice). This was the only vitric sample $>20 \mathrm{Ma}$ (See Figure 3-3 for the first round of LMT separates for this sample). Precipitation is the interpreted hydration water, based on volcanic rocks surrounding the unit, and a lack of fluvial or lacustrine deposits nearby (McClaughry, Ferns, Streck, et al., 2009).

\section{Picture Gorge Ignimbrite - 26.94 Ma (M2-CVG036)}

A rhyolitic ash flow tuff near the middle of the John Day Formation, interpreted to be erupted from a vent in the Ochoco Mountains (Fisher, 1966) and dated using K-Ar (Fiebelkorn et al., 1982). Sample is vitric, welded and light gray.

\section{Tuff of Foster Dam - 26.28 Ma (M1-CVG001, M2-CVG023)}

I collected this sample from a massive outcrop along the road near Foster Reservoir. It is off-white toward tan, taken near the bottom of the unit, below a welded zone with fiamme, but above a lower, green, and altered section. The sample contains broken phenocrysts of plagioclase and sanidine. Lithics are typically flowbanded rhyolite and andesite. It is dated using ${ }^{40} \mathrm{Ar} /{ }^{39} \mathrm{Ar}$ (McClaughry et al., 2010).

The unit is interpreted as a valley-filling ash-flow tuff, likely filling a stream and/or flood plain, based on the tuffaceous sandstone at the base of the unit which contains extensive carbonized wood and leaves, as well as an underlying conglomerate. I interpret this sample to have been hydrated by precipitation and/or stream water.

\section{Mascall Formation - 16 Ma (M2-CVG034, M2-CVG035)}

Most ash-fall tuffs in this formation are rhyodacitic in composition and considered to be derived from distal volcanism, perhaps from mid-Miocene calderas east of the Cascades Arc, within the Cascades Arc, or from the McDermitt volcanic field near the Oregon-Nevada border (Bestland et al., 2008). The tuffs are interpreted to have been reworked in an alluvial plain (Bestland et al., 2008).

The Upper Mascall Formation is marked by clay-rich fossil-soils, ash beds, and tuffaceous sediments. The Dreamtime Tuff (M2-CVG035) is fluvially-reworked ash about one meter thick, crystal poor, and grades into an overlying fossil-soil (Bestland et al., 2008). The Kangaroo Tuff (M2-CVG034) is an ash of similar texture that appears off-white toward yellow and can be up to several meters thick. Hydration water for these samples is interpreted as precipitation and/or stream water.

The lower Mascall Tuff Bed has a K-Ar date of 16.2 Ma \pm 1.4 Ma (Fiebelkorn et al., 1982). Swisher (1992) reported ${ }^{40} \mathrm{Ar} /{ }^{39} \mathrm{Ar}$ date of $15.77 \pm 0.07 \mathrm{Ma}$ for a tuff in the base of the formation. Magnetostratigraphy (Prothero et al., 2009) places Mascall fauna between 16.0 - 14.8 Ma, with the majority 15.3-15.1 Ma. We use 16.0 
- 14.8 Ma as the total range of age uncertainty for tuffs sampled within the Mascall Formation with the ${ }^{40} \mathrm{Ar} /{ }^{39} \mathrm{Ar}$ date of $\sim 15.77 \mathrm{Ma}$ used as the average. This date is chosen because it is in relatively good agreement with the age estimates based on fauna.

The $7.05 \pm 0.01 \mathrm{Ma}$ (Streck and Grunder, 1995) Rattlesnake Formation (M2CVG038) unconformably overlies (7-8 ${ }^{\circ}$ angular unconformity) the upper unit (Bestland et al., 2008).

Simtustus Formation - 12-15 Ma (M2-CVG030)

The Simtustus Formation is interpreted to have filled a low-relief paleovalley, with aggradation possibly due to drainage disruption caused by the Columbia River Basalt flows (CRBs) (Smith, 1985). Most ash in this formation is dacitic in composition, likely sourced from vents within the Cascade (Smith, 1985; Dill, 1988). Tuff from the Simtustus Formation was collected near Pelton Dam at the Simtustus Reservoir(Dill, 1988). I collected the sample from a thin but massive bed of fine, light-gray ash within crossbedded, tuffaceous sediments.

The sample is interpreted as ash reworked in a fluvial environment. Although the texture of this unit is massive, it may have been homogenized by bioturbation (Smith, 1985). Cross-bedded tuffaceous sandstones overlie and underlie the unit.

The age of the Simtustus Formation is poorly constrained, with $15.5 \mathrm{Ma}$ Columbia River Basalt conformably underlying and the 7.6 Ma Pelton Basalt unconformably overlying the unit. Smith (1985) suggests that this unconformity represents at least a 5 Ma gap in deposition. The age range for this formation is considered between 15 and 12 Ma based on evidence of pre-12 Ma fauna (Smith, 1985).

Devine Canyon Tuff - 9.68 Ma (M1-CVG020, M1-dc02-09, M2-CVG040)

The Devine Canyon Tuff is a crystal-rich ignimbrite sheet, interpreted to have been deposited on a low-relief plain, based on widespread, tabular beds of constant thickness over long distances (Greene, 1973). ${ }^{40} \mathrm{Ar} /{ }^{39} \mathrm{Ar}$ dating is by Jordan and others (2004). M1-CVG020 is a partially welded sample. Samples M2-CVG040 and M1-dc02-09 were taken from a non-welded to partially welded outcrop at Drinkwater Pass in eastern Oregon. This unit overlies a bed of diatomite and M2CVG040 had diatoms present (Figure B-1). Therefore, hydration water was likely lacustrine. I did not collect the sample from this locality analyzed with Method 1 (M1-dc02-09) and its exact location is not verified. 


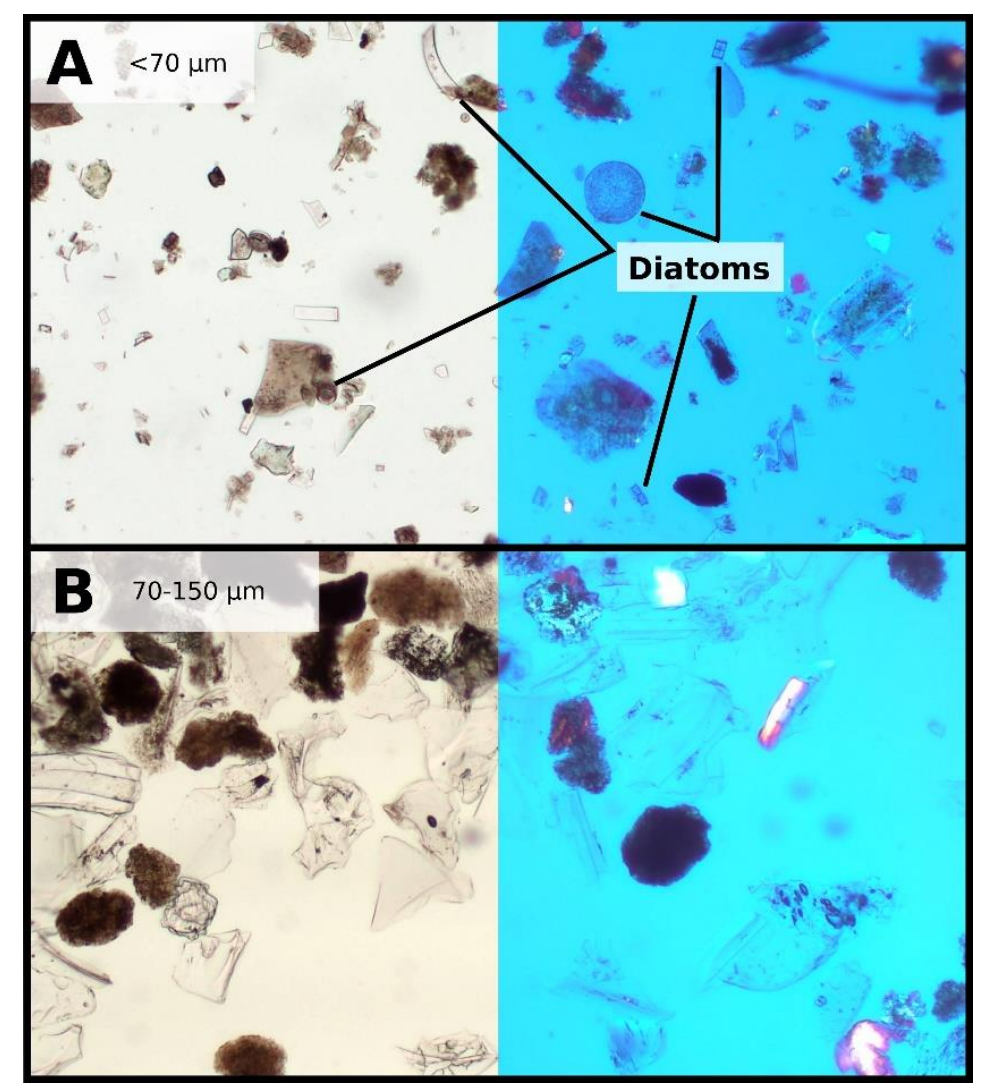

Figure B-1. Sample CVG040 viewed under plane light (left) and crossed polarized light with a full-wave retardation plate (right). A.) Raw sample with diatoms of various shapes and sizes present. Viewed under crossed polars with a full-wave retardation plate. B.) Sample after one round of HF, which dissolved all diatoms. This separate has undergone two LMT separations. This separate was below the analyzed separate in the funnel, and is therefore slightly more contaminated with dark glass and minerals. However, even the analyzed sample has purity $<99 \%$, and ideally, a third LMT separation would have been performed. Time and remaining sample availability limitations prohibited this.

\section{Rattlesnake Tuff - 7.1 Ma (M1-CVG019, M1-CVG019f, M1-CVG021, M2- CVG038, M2-CVG039)}

The Rattlesnake Tuff is crystal-poor (typically $<1 \%$ ), composed largely of high-silica ( $>75 \mathrm{wt} \% \mathrm{SiO} 2$ ) rhyolitic glass, and is interpreted to have erupted from the Harney Basin in southeastern Oregon. It has been dated using ${ }^{40} \mathrm{Ar} /{ }^{39} \mathrm{Ar}$ (Jordan et al., 2004). It is a relatively thin $(\sim 10-30 \mathrm{~m})$, widespread ignimbrite sheet. Much of the unit is densely welded or devitrified, however, the base of the tuff is non-welded where exposed.

Samples M1-CVG019f, M1-CVG019, and M2-CVG039 overlie a conglomerate (Stop \#9 of Streck and Ferns (2004)). In this exposure, samples in the basal $\sim 1 \mathrm{~m}$ contained almost exclusively clear glass shards. M1-CVG019f is from a $\sim 0.5 \mathrm{~m}$ thick bed at the very base of the section that contains clear, coarse-grained friable glass shards. Although geochemical analyses were not carried out on the sample, it may represent a compositionally distinct, slightly more evolved magma (higher $\mathrm{U}, \mathrm{Th}$, and Ta concentrations) relative to the top of the magma chamber (Streck and 
Grunder, 1995). Samples M1-CVG019 and M2-CVG039 were collected from directly above M1-CVG019f. In Method 1, two samples of similar texture were taken $<10 \mathrm{~cm}$ apart in the non-welded portion of the unit, above the coarse M1-CVG019f layer (Figure B-2). One sample (M1-CVG019b) had a salt-and-pepper appearance, and the other (M1-CVG019a) had exclusively clear shards. The coarser-grained M1-CVG019f sample showed more evidence of surface precipitates compared to CVG019 samples. This section is at the base of the flow, with thick, welded, vapor phase and devitrified zones above.

M1-CVG021 and M2-CVG038 are collected from non-welded basal portions of the unit and are similar in texture to M1-CVG019 and M2-CVG039. M1-CVG021 is from the Rattlesnake type section, Stop 7 of Streck and Ferns (2004), which overlies buff colored, poorly consolidated tuffaceous sediments that are common in the Harney Basin. Sample M2-CVG038 was taken from the non-welded ignimbrite base near $\sim 16$ Ma Mascall Formation samples ( $<3 \mathrm{~km}$ away). Hydration waters are interpreted as precipitation and/or stream water for these samples. 


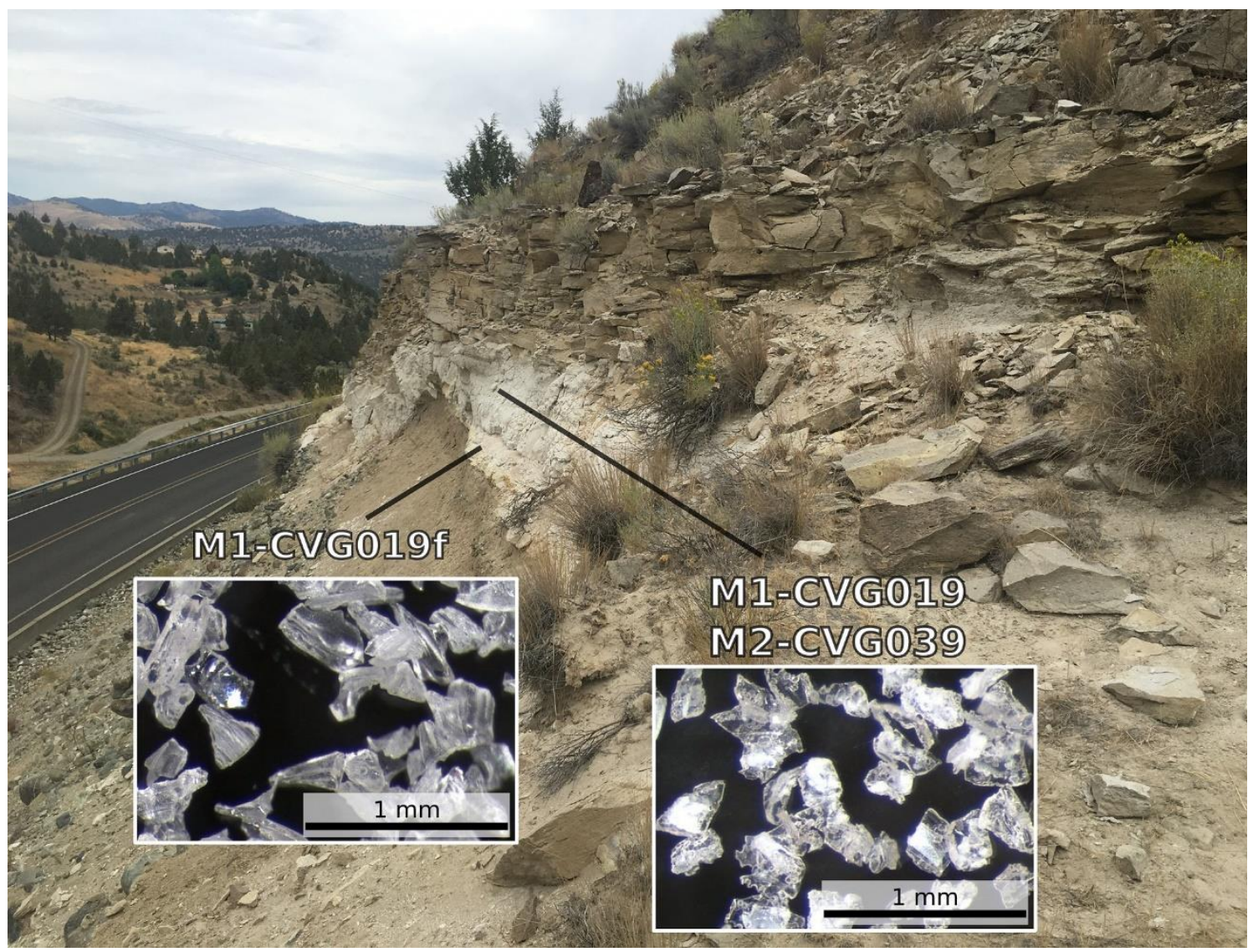

Figure B-2. Outcrop locality of Rattlesnake Tuff samples. The very friable, relatively large glass shards (M1-CVG019f) 0.5m above (M1-CVG019, M2-CVG039). CVG019f is has a relatively dull luster and thick bubble wall shards, while CVG019 and CVG039 have thinner bubble walls, and a vitreous luster. Only a small amount was within the 212-125 $\mu \mathrm{m}$ fraction, and even less within the $70-150 \mu \mathrm{m}$ fraction, it was therefore not analyzed using Method 2. Above these sampled units are a partially welded to densely welded and devitrified sections of the Rattlesnake Tuff. The unit overlies a conglomerate, cobbles from which can be seen toward the road.

\section{Deschutes Formation - $5 \mathrm{Ma}$ (M2-CVG028, M2-CVG027)}

The ashes in this unit are interpreted to be sourced from Cascade Arc vents that have since been buried due to subsidence and lava flows (Smith, 1985; Dill, 1988). Although the unit is not dated, it is bounded by the Jackson Butte Tuff below $(5.98 \pm 0.01 \mathrm{Ma})$ and the Fly Creek Tuff above $(5.68 \pm 0.01 \mathrm{Ma})$ (Pitcher et al., 2017). Samples of the Deschutes Formation were taken from Tuff Thirteen (Tdt13) as described by Dill (1988). Two samples were collected from nearby outcrops of the same unit. The section is pumice-poor and interpreted as a channel-filling ash flow deposit, based on paleocanyon dip measurements of underlying coarse sandstone from Dill (1988). Above Tuff Thirteen is a thick bed of pumice lapilli, additional tuff units and a lithic breccia (Dill, 1988). Hydration waters are interpreted as precipitation and/or stream waters.

Tuff of Friend - 4 Ma (M1-CVG014, M2-CVG014) 
The source of this tuff is not currently known, but it has been dated using ${ }^{40} \mathrm{Ar} /{ }^{39} \mathrm{Ar}$ (McClaughry et al., 2016). It is a welded tuff with fiamme and lithic fragments. The glass itself is a dark gray-brown color. The tuff is permeable with an ashy, gray groundmass. (McClaughry et al., 2010). The outcrop exhibits various orientations within large slabs, suggesting slumping has occurred. The unit outcrops in the middle of a grassy forest with no known units exposed nearby, making accurate determination of a depositional environment difficult. The hydration water is interpreted to be precipitation and/or stream water. This sample is unique, with dark glass that was magnetic down to 0.1 amps on the Frantz magnetic separator. It is possible that the dark color of this sample is due to iron oxide microcrystals (Schlinger et al., 1988).

\section{Quaternary ash - < 0.05 Ma (M2-CVG029)}

I collected this sample near the top of the Billy Chinook Reservoir canyon along the Deschutes River. The unit is massive, light beige and friable with broken phenocrysts. The only grains larger than sand size are pumice fragments. The ash appears to fill a surface depression in the intracanyon lava flow it overlies, which is dated at $\sim 50 \mathrm{Ka}$ (Peterson and Groh, 1970). It is interpreted to be reworked (aeolian) ash as it is very well sorted and lacks fluvial sedimentary structures. The hydration water is interpreted to be precipitation and/or stream water.

\section{C - Preparation Methods}

\section{Method Choice Considerations Method 1}

These methods are a modified version of those employed by Seligman and others (2016) and Dettinger and Quade (2015). Units with little to no evidence of devitrification under a petrographic and/or hand sample microscope were selected for analysis. These were crushed with a ceramic mortar and pestle. They were then put in labeled glass beakers filled with deionized (DI) water, sonicated for at least 30 minutes and repeatedly rinsed and decanted with DI water to remove clays. Samples were dried overnight in an oven at $60^{\circ} \mathrm{C}$ and dry-sieved using metal sieves. The 212-125 $\mu \mathrm{m}$ size fraction was treated in $10 \%$ hydrochloric acid $(\mathrm{HCl})$ for two 30 second intervals with DI rinses in between to remove possible carbonates. Seligman et al. (2016) did not use $\mathrm{HCl}$, but all samples were young $(<10 \mathrm{Ka})$ ashes. No sample analyzed with Method 1 showed effervescence with $\mathrm{HCl}$ to the naked eye. Samples were sonicated a second time in DI water for at least 30 minutes, decanted, and dried overnight at $60^{\circ} \mathrm{C}$. Approximately $10 \mathrm{mg}$ of shards (enough for 2-3 replicates of $2-3 \mathrm{mg}$ ) were individually hand-selected with tweezers under a binocular microscope based on morphology. Purity was checked on a watch glass under crossed polarized light and any grains showing birefringence indicative of mineral contamination were removed. Although it was quite easy to identify crystals in 
separates, grain sizes made it difficult to discern mineral contamination on the shard surface with a petrographic microscope.

\section{Considerations}

$\mathrm{HCl}$ treatment and sonication may not be adequate enough to remove all contaminants on the surfaces of glass (Cassel and Breecker, 2017). Large shard size (212-125 $\mu \mathrm{m}$ in Method 1 versus 150- $70 \mu \mathrm{m}$ in Method 2) made petrographic analysis difficult (Figure C-1). Temporary slides of these samples often had large bubbles in the immersion oil, and some shards were too thick or dark to adequately assess the degree of alteration. It is also more challenging to avoid pumiceous shards or shards with adhering phenocrysts in hand selection (Method 1) compared to heavy liquid separation (Method 2). The large grain size may also lead to incomplete hydration, and a greater amount of contamination from residual magmatic water (Cassel and Breecker, 2017).

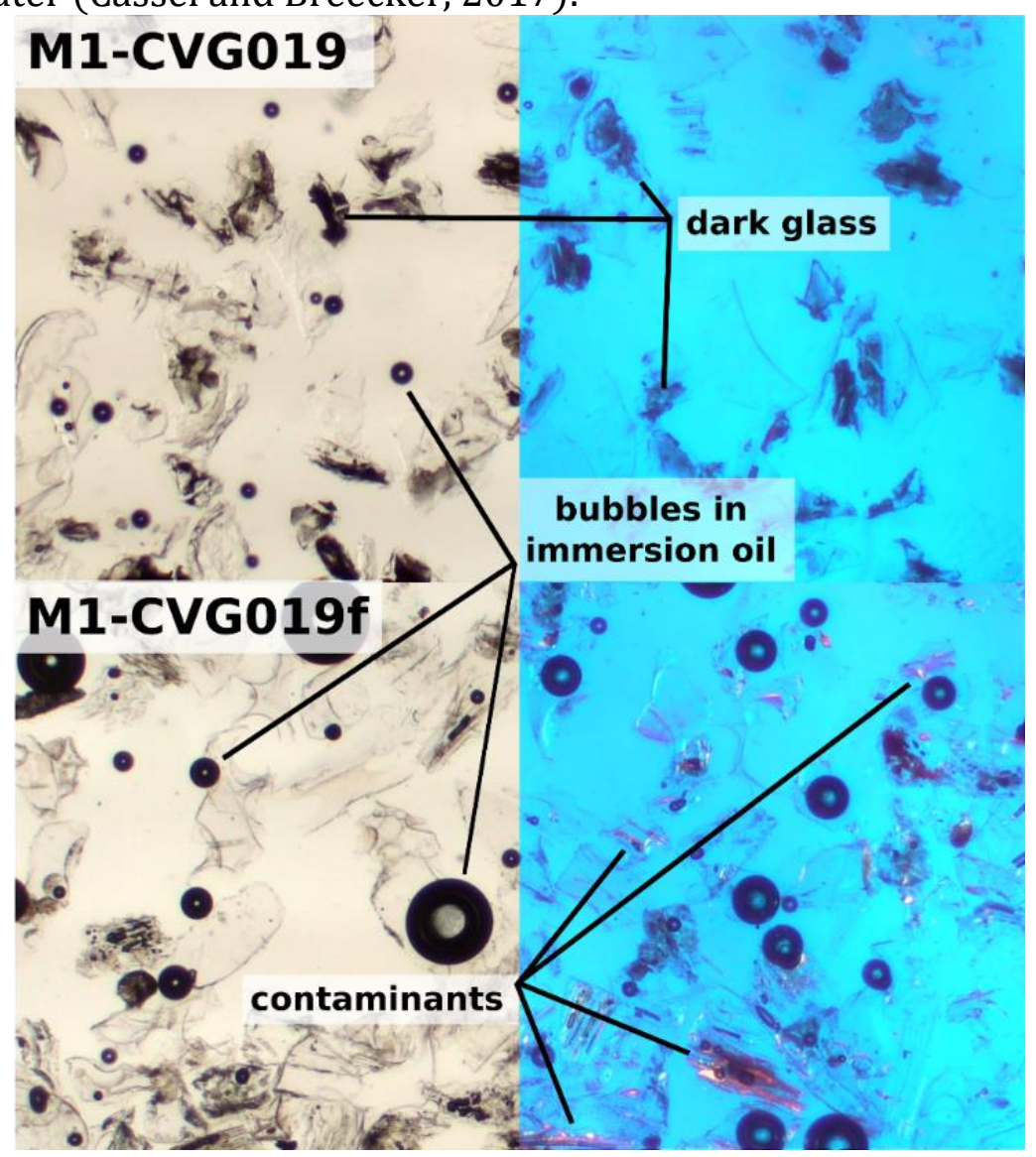

Figure C-1. Immersion oil slides of two different textures of Rattlesnake Tuff from the same location, prepared according to Method 1. Left side of image is plane light, and right side is crossed polarized light with a full wave retardation plate. Bubbles within immersion oil slides are visible in both samples, due to the large grain size compared to Method 2 samples. The top sample (M1-CVG019) was more indurated and fine grained than the lower sample (M1-CVG019f). The coarser sample also exhibits evidence of surface alteration after $\mathrm{HCl}$ and sonication preparation according to Method 1. 


\section{Method 2}

These methods follow those employed by Cassel and Breecker (2017). It is also similar to that which has been used by the USGS since the 1970s originally, modified from Sarna-Wojcicki (1984). Samples were crushed with a ceramic mortar and pestle and wet-sieved to various size fractions $(<70 \mu \mathrm{m}, 70-150 \mu \mathrm{m}$, and $>150$ $\mu \mathrm{m}$ ) using disposable nylon mesh to prevent contamination from metal sieves or between samples. Separates were vacuum filtered using ashless filter paper and dried overnight in an oven at $60^{\circ} \mathrm{C}$. The smaller grain sizes have been shown to better ensure complete conversion to molecular hydrogen in TC/EA analysis for various hydrous minerals (Gong et al., 2007; Qi et al., 2014). Temporary glass slides were made of the 70-150 $\mu \mathrm{m}$ size fraction with 1.5105 refractive index immersion oil to check for the presence of bubble wall shards and the degree of alteration. They were analyzed petrographically in crossed and uncrossed polarized light with and without a full-wave retardation plate to estimate the percentage of pure, isotropic glass.

To remove any possible carbonates, all samples within this size fraction were washed twice in $10 \% \mathrm{HCl}$ for approximately 30 seconds, and thoroughly rinsed with deionized (DI) water between acid treatments. Samples were then abraded with 8\% HF for two 30 second intervals, with DI water rinses in between. This removes surface precipitates, altered glass, and the outer rim of the passivating layer, in addition to dislodging fragments that may be stuck together. Samples were dried overnight in a fume hood and then wet-sieved back to $<70 \mu \mathrm{m}$ and $70-150 \mu \mathrm{m}$ size fractions using DI water. Samples were re-analyzed petrographically to determine if additional HF abrasion was necessary. Samples that still appeared altered after two rounds of HF treatment were typically not suitable for analysis. Very little sample is left after $\sim 2$ total minutes of $8 \% \mathrm{HF}$ abrasion, and samples that still show evidence of alteration typically contain no fresh glass. Step-by-step procedures for Method 2 are below.

\section{Considerations}

It can be difficult to know how much sample will be consumed with each preparation step, so large amounts of raw, ground sample are needed $(\sim 200-500 \mathrm{~mL}$ or $\sim 0.5-1.5 \mathrm{~kg}$ ). Some samples with high vesicularity or thin walls may completely dissolve in HF, while others only have a small amount of glass within the target size fraction to begin with. A maximum of $\sim 50 \mathrm{~g}$ of sample can be separated using LMT at one time. However, with this method, some samples had $>15 \mathrm{~g}$ of separates of $\geq 99 \%$ purity. Other samples had $\sim 10$ mg of separates with $\geq 99 \%$ purity, barely enough for two $\sim 3 \mathrm{mg}$ replicate analyses. Therefore, using this method, some samples may have extra material thoroughly prepared for other analyses of interest with no increased time requirement, while other samples may be destroyed entirely (Figure C-2). 


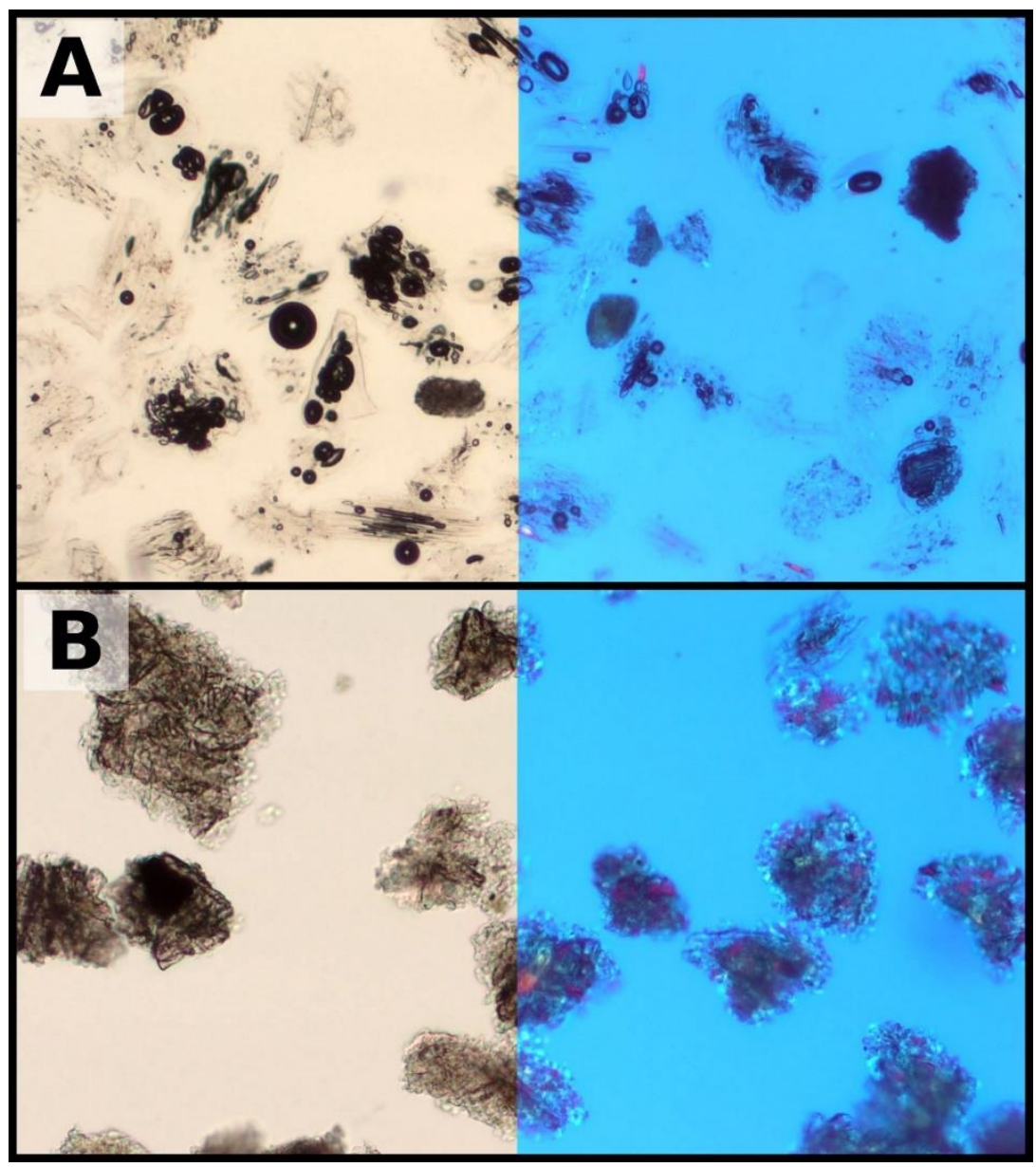

Figure C-2. Examples of samples that were prepared using Method 2 but were not analyzed. A.) M2CVG033 - this sample was highly pumiceous throughout, and had a high surface-area-to-volume ratio. It showed evidence of surface precipitates after one round of HF abrasion (pictured) and was completely destroyed upon an attempted second round. B.) This sample (M2-CVG037) was heavily altered after one round of HF abrasion, with little sample remaining. 


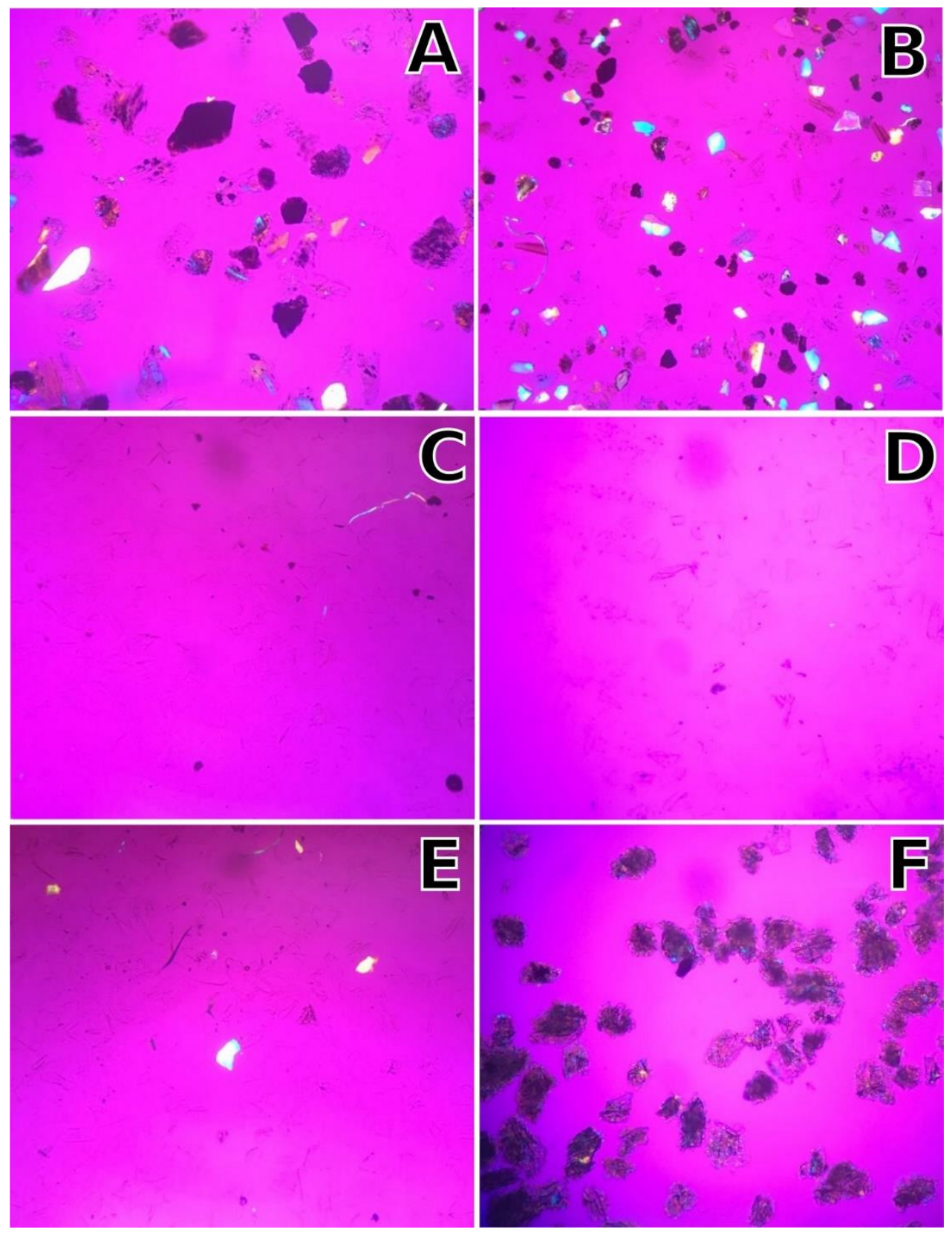

Figure C-3. Temporary immersion oil slides of 70-150 $\mu \mathrm{m}$ samples following acid abrasion, viewed with a full wave retardation plate. Visible fibers are from filter paper and are removed before analysis. A.) A sample (CVG035) that needed an additional HF treatment to remove contaminants before further separation. B.) A sample (CVG033) that needed Frantz magnetic separation and heavy liquid separation due to presence of dark, likely magnetic minerals as well as birefringent, nonmagnetic minerals. C.) A sample (CVG038) that only needed Frantz magnetic separation to reach $\geq 99 \%$ purity. D.) A sample (CVG034) that is $\geq 99 \%$ pure and ready for analysis. E.) A sample (CVG034) that only needed LMT separation to reach $\geq 99 \%$ purity. F.) A sample (CVG037) that was discarded due to extensive alteration of glass shards. 
Step-by-step preparation steps for Method 2

Note: all supplies are cleaned with Liquinox detergent, triple DI rinsed, and dried before use.

Temporary Immersion Oil Slides

Personal Protective Equipment:

- Gloves

Supplies:

- Ground sample

- Fine tip permanent marker

- Dissection needle

- Kimwipes

- 1.5105 refractive index immersion oil (Type A)

- Glass slides

- Glass cover slips

- Ethanol squirt bottle

- Scooping tool

1. Wipe down work station and place two pieces of paper on top of one another to work on

2. Label slide with descriptive sample labels using a fine point permanent marker. (2-3 coverslips can fit on one slide)

3. Put 1-2 drops of immersion oil on slide

4. Dip dissection needle in immersion oil and roll around slightly to coat

5. Scoop a little bit of sample out of container with scooping tool and dip the dissection needle in it to pick up some sample

6. Carefully roll needle around in immersion oil to distribute sample throughout

7. Pick up cover slip by edges to avoid finger prints. Gently rest one side of cover slip along slide, next to the immersion oil. Slowly lower cover slip onto immersion oil, avoiding creating bubbles.

8. Store slides short-term on tray lined with paper

9. In between samples, clean off and/or replace top layer of workspace paper, wipe dissection needle with dry kimwipe and then kimwipe with ethanol.

\section{Crushing}

Personal Protective Equipment:

- Silica dust mask respirator (with N95 filter)

- Gloves

- Safety glasses or goggles

Supplies:

- Ceramic mortar and pestle (multiple, as they are likely to break) 
- Ethanol

- Kimwipes

- Sledge hammer (if pieces are too large to fit in mortar)

- $\sim 0.5-1 \mathrm{~kg}$ of sample

- Ceramic bowl(s)

- Sample bags or a beaker with parafilm

- Tweezers

- Parafilm

Note: Do not use a rock crusher/grinder for these samples, unless it is fitted with ceramic (not metal) plates. The metal filings react with and shorten the lifespan of LMT (\$700/liter).

1. Ensure you are in a room with good ventilation, away from other people and all doors are closed to keep dust down.

2. Wear protective eye gear and a silica dust mask respirator

3. Wipe down all surfaces and equipment

4. If necessary, break rocks into small chunks ( $\lesssim 5 \mathrm{~cm}$ diameter) with a sledge hammer. Plan to crush $\sim 0.5 \mathrm{~kg}$ or more for each sample.

5. Place small amount of sample $(\sim 50 \mathrm{~g})$ in a ceramic mortar and pestle. It may be helpful to place the mortar on a shock-absorbing mat.

6. Using as little force as possible, gently break up the rock with light tamping or gentle rocking motion to better dislodge intact matrix shards and avoid pulverizing the sample.

7. As the size of the smallest rock pieces become heterogeneous during crushing, remove larger pieces and set them aside in a ceramic bowl, finish crushing any smaller pieces and pour them into a labelled container for storage. (Having small chunks of similar size in the mortar helps in dislodging shards and minimizes pulverization.)

8. Repeat steps 5-7 until the largest chunks are used up

9. Repeat steps 5-7 with the pieces you set aside in the ceramic bowl

10. Seal container of sample with labelled parafilm to prevent contamination or spilling (label BOTH container and parafilm).

11. Make temporary slides of samples to check for presence of glass shards

\section{Wet Sieving}

Personal Protective Equipment (optional)

- Gloves

- Safety glasses or goggles

Supplies:

- Nylon mesh in $150 \mu \mathrm{m}, 70 \mu \mathrm{m}$, and $30 \mu \mathrm{m}$ cut to $\sim 10 \mathrm{~cm} \times 10 \mathrm{~cm}$ (to fit inside of PVC pipes). 
- $30 \mu \mathrm{m}$ mesh is not necessary unless for some reason there is not enough glass in the 70-150 $\mu \mathrm{m}$ size fraction (e.g. after HF etching, there is very little sample in the 70-150 $\mu \mathrm{m}$ range, a 30-70 $\mu \mathrm{m}$ range can be used instead).

- Interlocking PVC pipes (mesh goes in between two)

- $\sim 500 \mathrm{~mL}$ crushed tuff sample

- Plastic tool to scrape sample on mesh (like small, dull ice scraper)

- Pencil and permanent marker

- Water wash bottle (plain or DI (after HF abrasion))

- Kimwipes

- $\quad 5$ large $(\sim 4000 \mathrm{~mL})$ plastic nalgene buckets

- Parafilm

- Ring stand

- Fit ring stand in sink above bucket, beneath sink faucet and put PVC pipe into ring stand. Ring can be wrapped in parafilm to increase the friction and keep PVC pipe from moving around.

- Ashless filter paper to fit funnel

- Vacuum pump filter fitted with Erlenmeyer flask and funnel

- Glass beakers

- $4000 \mathrm{~mL}$ polypropylene low form beakers (4-6)

1. Use a plastic sieve with disposable nylon screens $(150 \mu \mathrm{m}, 70 \mu \mathrm{m}$, and 30 $\mu \mathrm{m})$. Clean all surfaces, tools and crevices to prevent cross-contamination.

2. Use a permanent marker to label all sieve mesh before use with sample number and sieve size.

a. After use, rinse and dry them, wrap them in large kim wipes and save them for the second round of sieving (after acid abrasion)

3. Thoroughly clean/rinse all surfaces and tools to prevent cross-contamination (tap water is fine for rinsing and sieving at this stage, but after acid abrasion, only DI water should be used).

4. Place $4000 \mathrm{~mL}$ nalgene polypropylene low form beaker beneath a ring stand containing prepared sieve.

5. Add $\sim 300-500 \mathrm{~mL}$ of sample to sieve prepared with $150 \mu \mathrm{m}$ mesh (as much sample as fits into the sieve, while still being able to mix it around without spilling)

6. Wash water through sample by pouring or using a sink spray nozzle. (Using a plastic ice-scraper like tool can help move the sample around and force small particles through sieve more quickly).

7. Run water through the sample until the water falling into the bucket runs clear. This may take 2-5 buckets, depending on the number of clay-sized particles in the sample.

a. Set full buckets aside for sediment to settle 
8. Fold ashless filter paper in quarters (Fold in half and then in half again to make a quarter circle)

a. Label filter paper with pencil "[SAMPLE\#] $>150 \mu \mathrm{m}$ "

b. Place filter inside a glass funnel attached to a flask for vacuum filtering (squirting some water on the paper will help it stick to the sides of the funnel)

9. Carefully pry apart PVC pipes and remove the sieve screen with sample $(>150 \mu \mathrm{m})$ in it.

a. Pour sample into filter paper, using water in a wash bottle to help dislodge particles from the mesh

10. Vacuum filter.

a. Place filter paper with sample into a beaker

b. Dry in oven overnight at $60^{\circ} \mathrm{C}$

11. Carefully pour out the majority of water from full $4000 \mathrm{~mL}$ beakers, but do not pour out remaining sample $(<150 \mu \mathrm{m})$

a. Combine all sample into one beaker

12. Rinse all tools and areas once again to prevent contamination of separates

13. Place $70 \mu \mathrm{m}$ mesh in sieve with a clean beaker beneath it

14. Pour $<150 \mu \mathrm{m}$ sample fraction into the sieve and repeat steps 6 and 7

15. Repeat steps 8-10, but label filter paper "[SAMPLE\#] $70-150 \mu \mathrm{m}$ "

16. Repeat step 7 with a filter paper labelled "[SAMPLE\#] $<70 \mu \mathrm{m}$ "

17. Carefully pour off excess water in beakers and vacuum filter remainder of sample that has settled to the bottom $(<70 \mu \mathrm{m})$ as in step 9. (This will take longer than the last two filters, due to grain size).

18. Clean everything thoroughly between samples to prevent crosscontamination.

19. Make temporary slides of samples

\section{Acid Etching}

Personal Protective Equipment

- Material Safety Data Sheet for $\mathrm{HCl}$ and HF. Be sure to read this, be familiar with it, and have it on hand. If any HF contact occurs, you will need to take this to the emergency room with you.

- Spill kit

- $24 \mathrm{mil}(0.6 \mathrm{~mm})+$ butyl or neoprene gloves that go down past your lab coat sleeves. Check for integrity. Well-fitting, textured gloves are best. Wear two pairs of nitrile gloves under these.

- Wear a long-sleeved shirt and long pants under your lab coat

- Closed toed, waterproof shoes (eg: waterproof leather work boots) or booties

- Face shield

- PVC, silver shield, or other acid resistant apron 
- Calcium gluconate (Calgonate) gel

- Buddy (this is a PSU requirement)

\section{Supplies:}

- Large plastic Nalgene buckets labelled ( $\mathrm{HCl}, \mathrm{HCl}$ waste, $\mathrm{HF}, \mathrm{HF}$ waste, DI water)

- Plastic beakers for sieved samples (samples shouldn't fill more than $1 / 10$ of the beaker volume. DO NOT USE GLASSWARE WITH HF.

- Plastic stirring rod and heavy-bottomed plastic beaker to store it in

- $\mathrm{HCl}$ (Hydrochloric acid)

- HF (Hydrofluoric acid)

- HNO3 (Nitric acid)

- DI water

- DI water squirt bottle

- Labelled plastic waste containers with tight seals (HF waste, $\mathrm{HCl}$ waste KEEP SEPARATE)

○ Prepared using this method, $~ 98 \%$ water, $1 \%$ acid, $1 \%$ sediment. Label it as such.

- Broom and dust pan

- Plastic container with lid for spills

- Sodium bicarbonate

- Timer

- Kim wipes

- Plastic basket for contaminated waste

- Access to emergency wash station

- Large plastic container for nitric acid soak

Notes:

Wear: long pants, closed toe shoes, a lab coat with long sleeves under, apron, two pairs of nitrile gloves beneath one pair of neoprene gloves, hair up, lab goggles and face shield (at least when pouring concentrated liquid).

If a small amount of acid is spilled inside of fume hood, squirt water on it to dilute and then wipe up with kimwipe. Put kimwipe into basket within fume hood for 24 hours to dry before sealing in plastic bag and putting in garbage. For larger spills, or spills of concentrated HF, follow HF safety protocol from SDS or institutional requirements.

\section{HCl wash}

1. Mix $\mathrm{HCl}$ to $10 \%$ - wear face shield while mixing and try to only mix the needed amount (Note: Always add acid to water, not vice versa). 
a. Put calculated amount of DI water into $\mathrm{HCl}$ labelled bucket

b. Under fume hood, add calculated amount of $\mathrm{HCl}$

2. Fill DI water in labelled bucket and put under fume hood along with empty $\mathrm{HCl}$ waste labelled bucket, samples in parafilm-covered plastic beakers, plastic stirring rod and beaker, and DI water squirt bottle.

3. Squirt a little bit of water into the crucible. This helps dislodge any grains that may stick to the stirring rod. Always rinse stirring rod 2-3 times with DI water squirt bottle into waste bucket after use.

4. Take beaker of sample to acid wash. Carefully pick up $10 \% \mathrm{HCl}$ with both hands on either side of bucket and pour acid in plastic beaker until it covers the sample with approximately three times the amount of liquid as sample. Note the time and gently stir $\sim 20$ seconds, allow to settle for $\sim 10$ seconds and then decant liquid

5. Pour DI water from bucket into sample and stir again. Fill at least $2 x$ the volume DI as HF. Let settle and decant

Optionally, start an acid wash of another sample while this one settles

6. Repeat steps 5-6 one more time for a total of two thirty second washes for each sample

7. Pour waste into a sealable, labelled waste container $(\sim 1 \% \mathrm{HCl}, \sim 1 \%$ sediment $\sim 98 \% \mathrm{H} 20$ ) and properly dispose of. It may be useful to use a plastic funnel to avoid spilling when filling waste containers.

\section{HF wash}

COMPLETE HF SAFETY TRAINING BEFORE USING HF.

Exposure to HF over an area the size of the palm of your hand can be fatal. Wipe up all drips as they occur. Exposure to HF may not hurt immediately. Treat any exposure as an emergency and follow MSDS safety protocol. Ensure fume hood is HF rated and in good condition.

1. Mix HF to $8 \%$ - wear face shield while mixing and try to only mix the needed amount

a. Put calculated amount of DI water into HF labelled bucket

b. Under fume hood, add calculated amount of HF

2. Fill DI water in labelled bucket and put under fume hood along with empty HF waste labelled bucket

3. Take beaker of sample that has been $\mathrm{HCl}$ washed (2x) and decanted. Carefully pick up 8\% HF with both hands on either side of bucket and pour acid in plastic beaker until it covers the sample with approximately two times the amount of liquid as sample. Note the time and gently stir 20 seconds, squirt a little water in every few seconds and continue stirring until you have stirred for 30 seconds total

a. Rinse stirrer 
4. Carefully decant beaker, trying not to lose much sample

a. Some samples may unavoidably entirely dissolve in $\mathrm{HF}$

5. Pour DI water from bucket into sample (fill at least $2 \mathrm{x}$ as full as HF) and stir for $\sim 20$ seconds, let settle and decant

a. Optionally, start an acid wash of another sample while this one settles

6. Repeat steps 4-5 one more time for a total of two thirty second washes for each sample

7. Pour waste into a sealable, labelled waste container $(\sim 1 \% \mathrm{HF}, \sim 1 \%$ sediment $\sim 98 \% \mathrm{H} 20$ ) and properly dispose of

8. Allow samples and waste basket to dry overnight under fume hood before moving on to next step.

9. The next day, re-sieve samples with $70 \mu \mathrm{m}$ mesh using DI water (this should only take one $4000 \mathrm{~mL}$ bucket of DI water per sample) and dry overnight, following similar procedure to the original sieving. Store $<70 \mu \mathrm{m}$ and 70 $150 \mu \mathrm{m}$ samples separately.

10. Check purity of samples using temporary slides with immersion oil and determine if they need a second round of HF abrasion if surface contaminants appear present

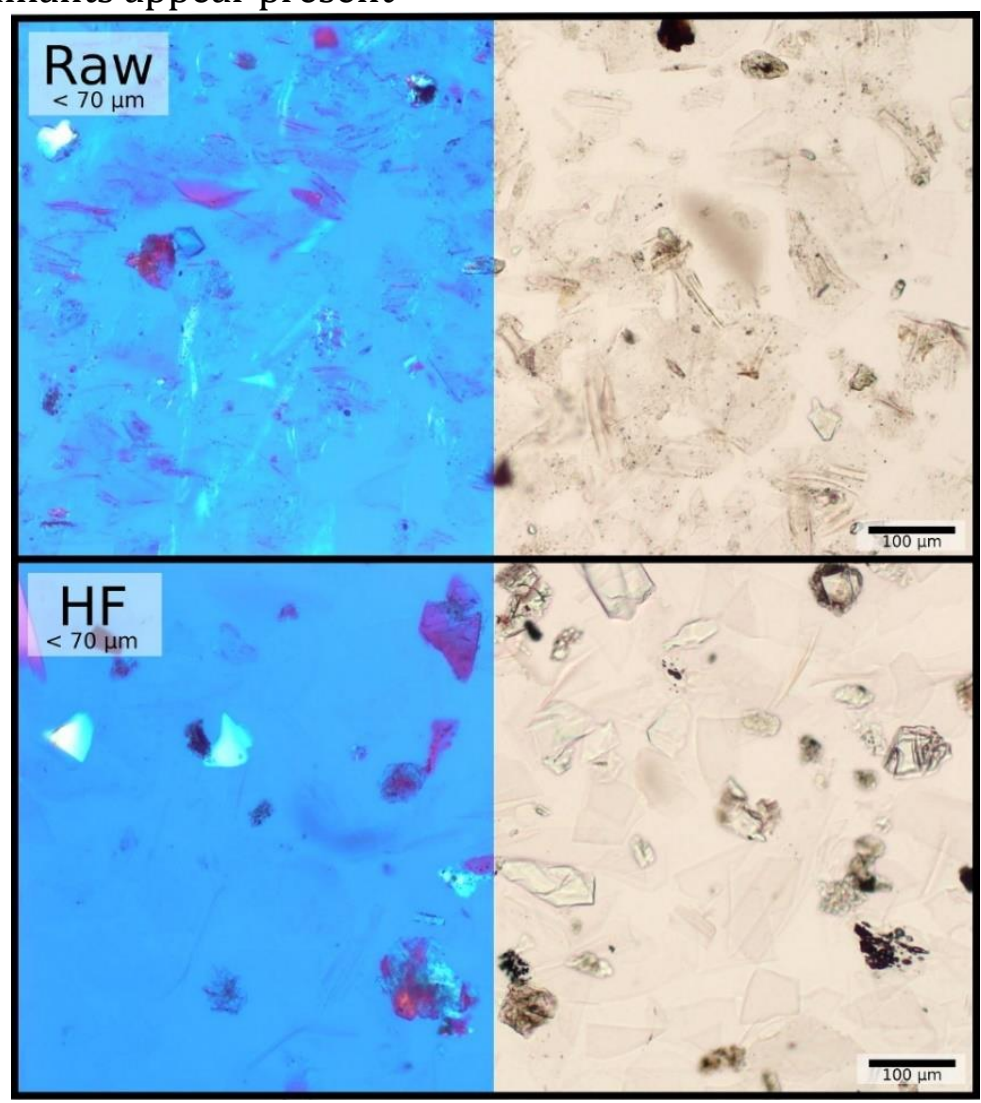

Figure C-4. Example of a sample (M2-CVG027) prior to HF treatment (Raw) and after one round of HF treatment (two 30 second baths). 


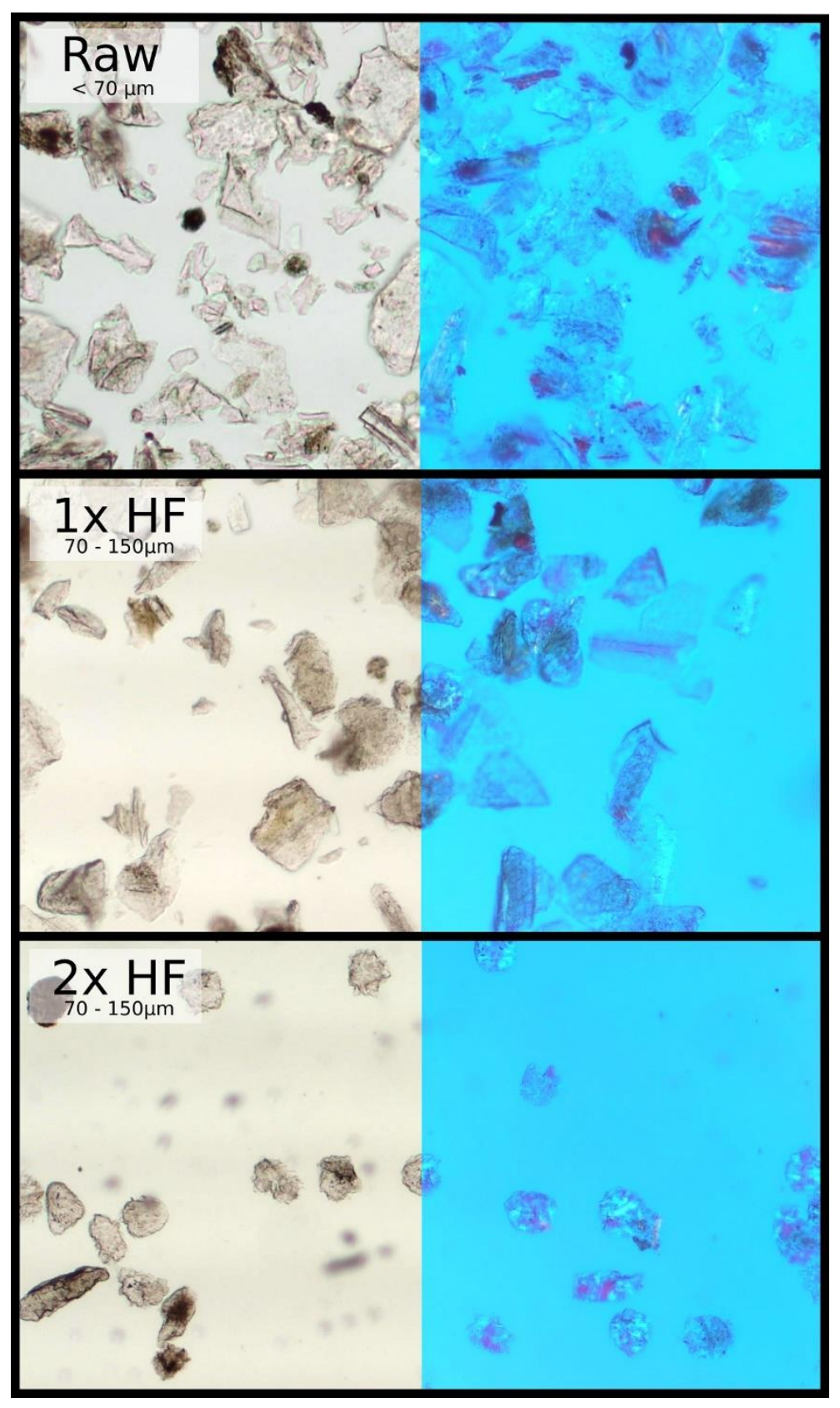

Figure C-5. An example of a sample that was altered/replaced throughout the entire shard morphology. Tuff of Foster Dam prepared with Method 2 protocol. Only $10 \mathrm{mg}$ of the $2 \mathrm{x}$ HF sample remained, as most of the glass had dissolved, leaving behind altered shard interiors, and decreasing surface area. This sample never reached $>99 \%$ purity, because the shards were heavily altered throughout, as seen in birefringent glass, even after two HF abrasion sessions (bottom). 


\section{Frantz Magnetic Separation}

Personal Protective Equipment (optional)

- Gloves

- Safety glasses or goggles

Supplies:

- Various sizes of weighing paper for wrapping separates

- Ethanol squirt bottle

- Kimwipes

- Permanent marker

- DI water squirt bottle

- Pull-to-release hand magnet

- Containers to catch magnetic and non-magnetic fractions

1. Run a pull-to-release hand magnet over samples to remove any highly magnetic grains

2. Take apart and clean Frantz. Do not touch areas where grains touch (chute), your hand oil will keep grains from sliding smoothly.

a. Rinse feeder tube with water, then ethanol, then dry with compressed air

b. Rinse separation containers with water, then ethanol, then wipe with kimwipes

c. Rinse chute with DI water and wipe with kimwipe (NO ETHANOL)

3. Adjust angle so that nonmagnetic grains will fall away from the magnet $\left(\sim 15^{\circ}\right)$

4. Pour sample into feeder container (sometimes it is necessary to tilt this back to keep sample from falling out freely)

5. Adjust amperage to $0.7 \mathrm{amp}$

6. Turn on vibration until grains only gently sprinkle out (1-3 grains at a time)

7. Watch grains as they fall. Some grains should stay on the magnetic side, while others fall away from the magnet to land in a separate container. If more than half of the grains are staying on the magnetic side, turn amperage down (try 0.5 all the way to 0.1 )

8. When complete, turn off Frantz.

9. Take magnetic and non-magnetic separates and pour onto separate weighing paper, fold up and tape

Label with sample name, mag/non-mag and amperage

10. Take apart and clean Frantz

11. Make temporary slides of separates

LMT Heavy Liquid Separation

Personal Protective Equipment:

- Gloves 
- Safety glasses or goggles

\section{Supplies (for one sample, can separate 2-3 at once):}

- Lithium metatungstate (LMT) at $\sim 2.7 \mathrm{~g} / \mathrm{cm}^{3} \sim 0.5 \mathrm{~L}$ per sample, must be recclaimed after use. Best to have at least $3 \mathrm{~L}$ on hand in order to prep several samples at once

- Plastic sealing container for LMT waste $(\sim 4000 \mathrm{~mL})$

- (2) $500 \mathrm{~mL}$ beakers (one labelled "WASTE" one labelled w/ sample number)

- (4) $100 \mathrm{~mL}$ or $250 \mathrm{~mL}$ beakers

- Ashless filter paper to fit funnel

- Pencil

- Watch glass that fits over $500 \mathrm{~mL}$ beaker

- Glass stirring rod

- Kimwipes

- DI squirt bottle

- Ethanol squirt bottle

- Custom cut separatory funnels with open top and stopcock for releasing liquid out bottom (label sample number with permanent marker)

- Vacuum pump

- (2) ring stands

- (2) rings

- Parafilm

- Two erlenmeyer flasks fitted with funnel to vaccuum filter (labelled "LMT", "Waste LMT")

- Hydrometer $\left(\sim 2.5-3 \mathrm{~g} / \mathrm{cm}^{3}\right)$ and volumetric column (or scale and volumetric flask)

Notes:

Be very careful with stirring rod, avoid hitting sides. Separation tubes are very fragile.

For any LMT spills, squirt DI water on it, wipe up with kimwipe and put in waste beaker with watch glass over it to keep it from drying out. Keep kimwipes wet as necessary by squirting water into waste beaker.

lid

Rinse off anything that comes in contact with LMT into waste container with

Regularly squirt water around inner edge of tube to dislodge any grains that become stuck to the side of the glass during mixing.

Avoid creating a whirlpool in the tube, which can destroy the density gradient and mix up existing layers. 
1. Wipe down all surfaces with DI water and kimwipes and then wipe down with ethanol and kimwipes. Wipe down all glassware with ethanol, other than separatory funnels. For separatory funnels, swirl with ethanol and then dry with compressed air.

2. Put stirring rod in $500 \mathrm{~mL}$ beaker and put beaker below ring stand. Wrap ring stand in parafilm if needed. Put separatory funnel through ring stand and set valve to closed.

3. Set out four small beakers for density separates.

4. Fold filter paper into quarter circles (one for each beaker) and label

a. Sample \# TT - Tube Top

b. Sample \# TU - Tube Upper

c. Sample \# TM - Tube Middle

d. Sample \# TB - Tube Bottom

5. Check density of LMT with hydrometer (or cacluate density with volumetric flask). If it is too dense, add a little bit of DI water, if it is not dense enough, follow LMT reclaim procedure to evaporate some water off. Be sure LMT is room temperature when checking density.

6. Pour $2.7 \mathrm{~g} / \mathrm{cm}^{3} \mathrm{LMT}$ a little more than halfway up the separatory funnel

7. Sprinkle in $\sim 50 \mathrm{~g}(\sim 2 \mathrm{TBSP})$ of sample while gently stirring with stirring rod to minimize clumping.

a. Rinse stirring rod with DI water into the tube

8. Squirt DI water into tube and mix with rod. You should see darker minerals and some lighter minerals sinking to the bottom where they may rest on the plug.

9. Allow grains to settle 5 - 10 minutes between mixings

10. Keep adding water and mixing until there is a density separation where a layer is clearly forming near the bottom-middle. This may take several iterations of adding water, mixing, and waiting for grains to settle.

11. After this layer is formed, mix to a shallower depth and continue adding water to create a density gradient that ideally has four layers, with the top being roughly the density of water (gradient from $2.7-1 \mathrm{~g} / \mathrm{cm}^{3}$ ) with the mixing depth decreasing as water is added.

12. Once there are four layers separated, place vacuum filter funnel attached to "LMT" flask with labelled filter paper (Sample \# TB) under the tube. Squirting a bit of DI water helps to get filter paper to stick. Open valve and allow TB layer to fall into funnel. Filter LMT through.

13. Once LMT is filtered through, the grains will quickly dry out and turn white. This is the LMT crystallizing on the shards. At this point, put funnel on "LMT waste" flask.

14. Squirt DI water all over sample, around filter paper and try to remove as much LMT as possible.

15. Take filter paper and put it in a small beaker, then dry in oven overnight $\left(60^{\circ} \mathrm{C}\right)$.

16. Repeat steps 10-15 for layers TM, TU, and TT 
17. Put LMT from "LMT" flask (slightly diluted and contaminated) into sealed beaker and label "Unfiltered LMT" This LMT needs to be filtered three times and then evaporated back down to $2.7 \mathrm{~g} / \mathrm{cm}^{3}$, see LMT reclaim methods.

18. Rinse anything that came in contact with LMT into waste container, wipe down surface with water and kimwipes and then wring out any used kimwipes in the LMT waste beaker and add to LMT waste bucket

19. Check purity of samples and re-LMT if necessary, only choosing the one or two best separates to re-LMT. Label sample separates in their own containers, with descriptive naming (see \#4). 
20.

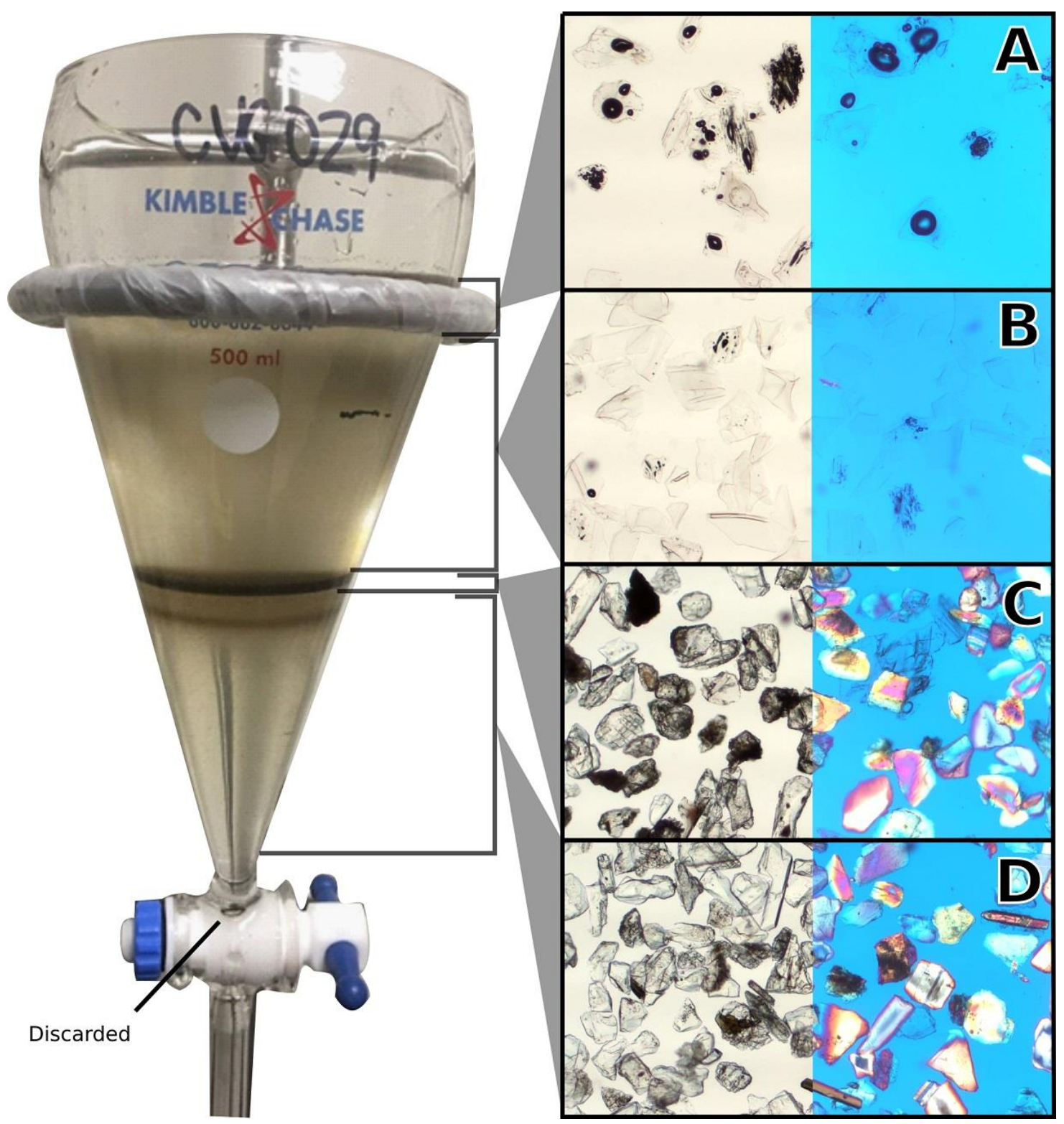

Figure C-6. An example of an ash sample (M2-CVG029) that has undergone a single round of LMT separation. Left half of each photo is uncrossed polarized light, and right half is crossed polarized light with a full wave $(1 \lambda)$ retardation plate (blue). All samples are $70-150 \mu \mathrm{m}$. Heavy minerals $\left(>2.7 \mathrm{~g} / \mathrm{cm}^{3}\right) \mathrm{sink}$ to the bottom and show up as a dark ring near the stopcock. These are discarded. Two distinct layers are visible near the center of the funnel. These layers are largely quartz and feldspar, as well as some heavier, darker glass $(D, C)$. Above these two layers, there is a diffuse layer of glass with density decreasing toward the top (B). Behind the ring at the top is the least dense, most pumiceous glass (A). For this specific sample, the completely sunken minerals, and Layers D and C are least desirable for analysis. Separate B had the largest mass, the purest glass, and the most bubble wall shards. It was selected for a second round of LMT to create $a \geq 99 \%$ pure separate with minimal pumiceous glass. 


\section{Re-claiming LMT}

It should be possible to reclaim $~ 99 \%$ of LMT with proper usage. Rinse everything that contacts LMT 2-3 times into the waste bucket. Squirt water on and wipe up any LMT spills with kimwipes, then squirt kimwipes with DI water to saturate, and then squeeze into waste bucket. Never use Ethanol to clean LMT. Clean with water first.

\section{Personal Protective Equipment:}

- Gloves

- Safety glasses or goggles

\section{Supplies:}

- Ashless filter paper, to fit in funnel for vacuum filtering

- Vacuum filter with funnel and Erlenmeyer flask

- $500 \mathrm{~mL}$ glass beakers

- Watch glass for LMT waste beaker to collect filter papers in

- Large, shallow plastic container

- Heat lamps with clamps

- Ring stands

- Hydrometer and volumetric column (or scale and volumetric flask)

\section{LMT from "LMT" flask ("Unfiltered LMT", slightly diluted and contaminated)}

1. Filter LMT using ashless filter paper 3 times (new paper each time, be sure to rinse filter paper and add to LMT waste bucket).

a. If you don't have time to do all three filters in one day, label beaker " $1 \mathrm{x}$ filtered LMT"

2. Put beaker in fume hood with a heat lamp clamped to a ring stand positioned above it (not too close). Leave fume hood open $\sim 1 / 3-1 / 2$ for air flow to speed up evaporation.

a. Once the beaker heats up, evaporation of water from the LMT should be visibly obvious

b. If a film begins to form on the top of the LMT, the lamps may be too close, and the sample likely is too dense and needs to be diluted.

3. Allow to cool and check density. Stop when at $2.7 \mathrm{~g} / \mathrm{cm}^{3}$

\section{LMT from waste bucket (wait until bucket is $>1 / 2$ full)}

1. Put waste in a large, flat container (like plastic tupperware) and put under heat lamp in fume hood as above (be extra careful not to melt the plastic). The thicker and dirtier the LMT is, the longer filtering will take. Typically $\sim 80 \%$ of the sample will evaporate before it is time to filter. 
2. When sample looks more yellow and has evaporated quite a bit, filter 3 times and continue to evaporate under heat lamps as above.

\section{Packing Samples for Analysis}

Personal Protective Equipment:

- Gloves

- Safety glasses or goggles

\section{Supplies:}

- Silver capsules ( $4 \mathrm{~mm} \times 6 \mathrm{~mm}$ or $3.5 \mathrm{~mm} \times 5.5 \mathrm{~mm})$

- Tweezers (fine tip)

- Small scooping tool (must fit inside sample separate storage containers)

- Scale that measures to $0.001 \mathrm{mg}(0.000001 \mathrm{~g})$

1. Wipe down all utensils and workspace with ethanol and kimwipes

2. Place two layers of paper on the workspace

3. Create data table with columns for sample number (must be unique, even for replicates), sample amount, and microplate aliquot number

4. Weigh a silver capsule in scale that is accurate to thousandths place in milligrams $(0.000001 \mathrm{~g})$ and tare the scale.

5. Weigh out $\sim 3 \mathrm{mg}$ of sample into silver capsule (depending on expected or known water content, $3 \mathrm{mg}$ is good for 3-4 wt. \% water, could need up to 10 $\mathrm{mg}$ for low water content).

6. Note weight for each sub-sample, which is necessary to calculate water content once you have results

7. Clamp top of capsule with tweezers and fold over once.

8. Begin to squish capsule with tweezers and flat end of picking/scooping tool into as round or square of a shape as possible (small radius) -> pancakes are bad! They can get clogged up in the machine

9. Put into microplate starting with the top left aliquot (A1 - A12, B1 - B12 etc.) and note tray location for the sample in data table

10. Repeat for as many replicates you would like for your sample (minimum 2). Put them next to each other. Make sure labels make replicates obvious, so the lab faculty will know to put standards in between clusters of replicates.

11. After all samples are loaded, put lid on microplate and tape together to keep lid on and ship for analysis

12. It is optional to distribute $\sim 5$ well-prepared glass samples with known isotopic composition to determine if there is intra-replicate variability in the same samples during the course of analysis (this would be in addition to inhouse standards that are incorporated into a new microplate that is loaded in the autosampler and used to correct for instrumental drift). 
13. The lab faculty will package their international and in-house standards and intersperse them in a new microplate with your samples. This is then dried overnight before being loaded in the autosampler for analysis.

\section{D - Sample Analysis}

\section{Method 1 Sample Analysis}

Samples from Method 1 were analyzed at the University of Oregon Stable Isotope Laboratory. Analysis follows Seligman and others (2016). Laboratory technicians analyzed samples for $\delta \mathrm{D}$ and wt. \% water using a thermal conversion/elemental analyzer (TC/EA) equipped with an auto-sampler and continuous-flow mass spectrometer. A minimum of two replicates were analyzed for each sample, and any samples that showed high variability or low water content within these replicates were analyzed a second time. Approximately 2-3 mg (up to $10 \mathrm{mg}$ for samples with low water contents) of prepared samples were weighed out and packaged into silver foil capsules. The samples were dried in a vacuum oven overnight prior to analysis to remove any water physically adsorbed to the shard surfaces. After vacuum drying, samples were immediately loaded into a zero-blank autosampler and flushed with He carrier gas prior to analysis. Ground NBS-30 biotite with a known concentration of water (3.5 wt.\%) is used to calculate water concentrations based on sample masses and peak areas. Grinding of the NBS-30 is necessary to ensure conversion to molecular hydrogen (Qi et al., 2014; Gong et al., 2007). If a sample had too low of water content for an accurate $\delta \mathrm{D}$ measurement (low peak areas) with $2-3 \mathrm{mg}$ of glass, up to $10 \mathrm{mg}$ of sample would be analyzed.

Three international standards were used to normalize measured values to standard mean ocean water (SMOW) via a three-point calibration (Seligman et al., 2016). Repeat analyses of standards yielded the following means: $\mathrm{W} 62001=-$ $38.0 \% 0 \delta \mathrm{D} \pm 0.2 \%$; Lk.Louise $=-145.0 \%$ o $\delta \mathrm{D} \pm 0.9 \%$; VSMOW $=3.0 \% 0 \delta \mathrm{D} \pm$ $0.0 \%$; NBS30 $=-53.4 \%$ o $\delta \mathrm{D} \pm 0.4 \%$; USGS57biotite $=-91.0 \% 0 \delta \mathrm{D} \pm 0.3 \%$ and USGS58muscovite $=-28.0 \% 0 \delta \mathrm{D} \pm 0.1 \%$. Standards dispersed at intervals were used to correct for instrumental drift and exhibited reproducibility. Mica corrected $\delta \mathrm{D}$ values were compared for consistency with Method 2. I averaged replicates and calculated intra-replicate ranges (Appendix E).

\section{Method 2 Sample Analysis}

I analyzed Method 2 samples at the Light Stable Isotope Lab at the University of Texas at Austin. Samples were analyzed for $\delta \mathrm{D}$ and wt. \% water using a thermal conversion/elemental analyzer (TC/EA) equipped with an auto-sampler and continuous-flow mass spectrometer. A minimum of two replicates were analyzed for each sample, and any samples that showed high variability or low water content within these replicates were analyzed again. Approximately 2-3 mg (up to $10 \mathrm{mg}$ for samples with low water contents) of prepared samples were weighed out and packaged into silver foil capsules (Costech, $4 \mathrm{~mm} \times 6 \mathrm{~mm}$ ). International standards, 
including ground NBS-30 biotite, and aliquots of an in-house volcanic glass standard prepared as per Cassel and Breecker (2017) were dispersed at regular intervals. The international standards were used to normalize measured values to standard mean ocean water (SMOW), while the glass standards were used to correct for instrumental drift. As in Method 1, ground NBS-30 biotite with a known concentration of water (3.5 wt.\%) was used to calculate water concentrations based on sample mass and peak areas. Repeat analyses of standards yielded the following means: NBS22 $=-121.0 \%$ o $\delta \mathrm{D} \pm 2.3 \%$; IAEA-CH7 $=-98.9 \%$ o $\delta \mathrm{D} \pm 0.5 \%$; IAEA-C3 $=-35.9 \%$ o $\delta \mathrm{D} \pm 2.9 \%$ and $\mathrm{NBS} 30=-46.9 \%$ o $\delta \mathrm{D} \pm 1.2 \%$. The internal natural volcanic glass standard SN09-052RW yielded a mean value of $-152.7 \%$ o $\delta \mathrm{D} \pm 2.1$ and 4.2 wt. $\% \mathrm{H}_{2} \mathrm{O} \pm 0.0$ (Appendix E). International standards were reproducible $\pm 2-3 \%$. Replicates were averaged, and intra-replicate ranges were calculated (Appendix E). 


\section{E - Additional Data Tables and Plots}

Table E-1. Samples collected, but not selected for analysis

\begin{tabular}{|c|c|c|c|c|c|}
\hline Name & Approximate Age & Latitude & Longitude & Reason & Source \\
\hline $\begin{array}{l}\text { Member A John Day } \\
\text { Formation }\end{array}$ & Oligocene & 44.80250 & -120.17472 & $\begin{array}{l}\text { Highly altered or } \\
\text { devitrified }\end{array}$ & $\begin{array}{l}\text { (McClaughry, Ferns, } \\
\text { Gordon, et al., } \\
\text { 2009) }\end{array}$ \\
\hline $\begin{array}{l}\text { Member G John Day } \\
\text { Formation - Teller Flat }\end{array}$ & Oligocene & 44.64477 & -120.76724 & $\begin{array}{l}\text { Highly altered or } \\
\text { devitrified }\end{array}$ & $\begin{array}{l}\text { (McClaughry, Ferns, } \\
\text { Gordon, et al., } \\
\text { 2009) }\end{array}$ \\
\hline $\begin{array}{l}\text { Member G John Day } \\
\text { Formation - Antelope } \\
\text { Creek }\end{array}$ & Oligocene & 44.84592 & -120.87552 & $\begin{array}{l}\text { Highly altered or } \\
\text { devitrified }\end{array}$ & $\begin{array}{l}\text { (McClaughry, Ferns, } \\
\text { Gordon, et al., } \\
\text { 2009) }\end{array}$ \\
\hline $\begin{array}{l}\text { Member H John Day } \\
\text { Formation }\end{array}$ & Oligocene & 44.49606 & -121.15731 & $\begin{array}{l}\text { Highly altered or } \\
\text { devitrified (zeolites) }\end{array}$ & $\begin{array}{l}\text { (McClaughry, Ferns, } \\
\text { Gordon, et al., } \\
\text { 2009) }\end{array}$ \\
\hline Tuff of Rodman Springs & Oligocene & 44.46241 & -121.11406 & $\begin{array}{l}\text { Highly altered or } \\
\text { devitrified }\end{array}$ & $\begin{array}{l}\text { (McClaughry, Ferns, } \\
\text { Gordon, et al., } \\
2009 \text { ) }\end{array}$ \\
\hline $\begin{array}{l}\text { Tuff of Smith Rock } \\
\text { Saddle }\end{array}$ & Oligocene & 44.51776 & -120.63739 & $\begin{array}{l}\text { Outcrop not found } \\
\text { (buried from logging } \\
\text { activity?) }\end{array}$ & $\begin{array}{l}\text { (McClaughry, Ferns, } \\
\text { Gordon, et al., } \\
\text { 2009) }\end{array}$ \\
\hline $\begin{array}{l}\text { Smith Rock Outflow } \\
\text { Tuff }\end{array}$ & Oligocene & 44.54560 & -120.64079 & Too welded & $\begin{array}{l}\text { McClaughry, } 2016 \\
\text { personal } \\
\text { communication }\end{array}$ \\
\hline Haystack Lower & Oligocene & 44.49482 & -121.15471 & $\begin{array}{l}\text { Highly altered or } \\
\text { devitrified }\end{array}$ & $\begin{array}{l}\text { (McClaughry, Ferns, } \\
\text { Gordon, et al., } \\
\text { 2009) }\end{array}$ \\
\hline Haystack Upper & Oligocene & 44.49557 & -121.15657 & $\begin{array}{l}\text { Highly altered or } \\
\text { devitrified }\end{array}$ & $\begin{array}{l}\text { (McClaughry, Ferns, } \\
\text { Gordon, et al., } \\
\text { 2009) }\end{array}$ \\
\hline Tuff of Eagle Rock & Oligocene & 44.19357 & -120.65243 & $\begin{array}{l}\text { Highly altered or } \\
\text { devitrified }\end{array}$ & $\begin{array}{l}\text { (McClaughry, Ferns, } \\
\text { Gordon, et al., } \\
\text { 2009) }\end{array}$ \\
\hline
\end{tabular}




\begin{tabular}{|c|c|c|c|c|c|}
\hline Tuff of McKay Saddle & Oligocene & 44.53804 & -121.15523 & $\begin{array}{l}\text { Highly altered or } \\
\text { devitrified }\end{array}$ & $\begin{array}{l}\text { (McClaughry, Ferns, } \\
\text { Gordon, et al., } \\
\text { 2009) }\end{array}$ \\
\hline Mascall Tuff & Miocene & 44.50333 & -119.61167 & $\begin{array}{l}\text { Dissolved in HF - too } \\
\text { high surface-area-to- } \\
\text { volume ratio }\end{array}$ & $\begin{array}{l}\text { (Bestland et al., } \\
\text { 2008) }\end{array}$ \\
\hline Tuff of Leslie Gulch & Miocene & 43.31427 & -117.21812 & $\begin{array}{l}\text { Highly altered or } \\
\text { devitrified }\end{array}$ & (Savoie, 2013) \\
\hline Dinner Creek Tuff & Miocene & 43.76686 & -118.02967 & $\begin{array}{l}\text { Highly altered or } \\
\text { devitrified }\end{array}$ & (Savoie, 2013) \\
\hline Bully Creek Tuff & Miocene & 44.07925 & -117.54358 & $\begin{array}{l}\text { Highly altered or } \\
\text { devitrified }\end{array}$ & (Savoie, 2013) \\
\hline Tuff of Egli Rim & Miocene & 43.00291 & -120.64079 & $\begin{array}{l}\text { Only basalt found in } \\
\text { vicinity }\end{array}$ & $\begin{array}{l}\text { McClaughry, } 2016 \\
\text { personal } \\
\text { communication }\end{array}$ \\
\hline
\end{tabular}


Table E-2. Sample preparation steps carried out for each sample using Method 2. Note that not all samples were analyzed (bold). Any sample with NA in a field did not require the respective step to reach purity (e.g. the Kangaroo Tuff had no evidence of magnetic minerals in thin section after HF treatment and went straight to LMT heavy liquid separation with no Frantz magnetic separation).

\begin{tabular}{|c|c|c|c|c|c|c|}
\hline Sample & Name & $\mathrm{HF}$ & $\begin{array}{c}\text { Frantz (Max } \\
\text { Amps) }\end{array}$ & LMT & Analyzed & Note \\
\hline CVG013* & Tuff of Dale & $1 x$ & 0.3 & $2 x$ & Yes & \\
\hline CVG036 & Picture Gorge Ign. & $1 x$ & 0.7 & $2 x$ & Yes & $<2$ wt. \% water \\
\hline CVG023* & Tuff of Foster Dam & $2 x$ & 0.7 & $1 x$ & Yes & Not $\geq 99 \%$ pure \\
\hline CVG037 & Member A JDF & $1 x$ & 0.7 & $1 x$ & No & Highly altered \\
\hline CVG033 & Mascall Tuff & $2 x$ & 0.5 & $1 x$ & No & Dissolved in HF \\
\hline CVG035 & $\begin{array}{l}\text { Mascall - } \\
\text { Dreamtime }\end{array}$ & $2 x$ & 0.3 & $1 x$ & Yes & \\
\hline CVG034 & Mascall - Kangaroo & $1 x$ & NA & $1 x$ & Yes & \\
\hline CVG030 & Simtustus Fm. & $2 x$ & NA & $1 x$ & Yes & \\
\hline CVG040* & Devine Canyon Tuff & $1 x$ & 0.7 & $2 x$ & Yes & Not $\geq 99 \%$ pure \\
\hline CVG039* & Rattlesnake Tuff & $1 x$ & 0.7 & NA & Yes & \\
\hline CVG038 & Rattlesnake Tuff & $1 x$ & 0.7 & NA & Yes & \\
\hline CVG027 & Deschutes Fm. & $1 x$ & 0.6 & $1 x$ & Yes & \\
\hline CVG028 & Deschutes Fm. & $1 x$ & 0.6 & $2 x$ & Yes & $\begin{array}{l}\text { Glass was magnetic } \\
\text { to } 0.1 \mathrm{Amp}\end{array}$ \\
\hline CVG014* & Friend & $1 x$ & 0.1 & $2 x$ & Yes & \\
\hline CVG029 & Quaternary & $1 x$ & 0.7 & $2 x$ & Yes & \\
\hline
\end{tabular}

* Analyzed using both Method 1 and Method 2 
Table E-3. Table summarizing data from all samples analyzed using either method (Method 1/Method 2). Range of water in relative percent is the average range in water concentration (wt. \%) divided by the total average water concentration (wt. \%) multiplied by 100 . $\Delta$ values between two methods are calculated from Method 2 - Method 1.

\begin{tabular}{|c|c|c|c|c|c|c|}
\hline & $\begin{array}{l}\text { Number of } \\
\text { Analyses }\end{array}$ & $\begin{array}{l}\text { Number of } \\
\text { Outcrops }\end{array}$ & $\begin{array}{l}\text { Average Number } \\
\text { of Replicates }\end{array}$ & $\begin{array}{l}\text { Average Water } \\
\text { Concentration (wt. \%) }\end{array}$ & $\begin{array}{l}\text { Average Range } \\
\text { Water (wt. \%) }\end{array}$ & $\begin{array}{l}\text { Average Range } \\
\text { Water (relative \%) }\end{array}$ \\
\hline Method 1 (All) & 24 & 9 & 2.67 & 4.06 & 0.61 & 15.06 \\
\hline $\begin{array}{l}\text { Method } 1 \text { ( } 2-10 \\
\text { wt. \% water) }\end{array}$ & 16 & 7 & 2.29 & 2.85 & 0.15 & 5.26 \\
\hline Method 2 (All) & 26 & 13 & 2 & 4.79 & 0.12 & 2.50 \\
\hline $\begin{array}{l}\text { Method } 2 \text { (2-10 } \\
\text { wt. \% water, } \\
\geq 99 \% \text { pure) }\end{array}$ & 20 & 10 & 2 & 4.41 & 0.09 & 2.04 \\
\hline $\begin{array}{l}\Delta \text { Method2 - } \\
\text { Method } 1 \text { (All) }\end{array}$ & 2 & 4 & -0.67 & 0.73 & -0.49 & -12.56 \\
\hline $\begin{array}{l}\Delta \text { Method2 - } \\
\text { Method } 1 \text { (2-10 } \\
\text { wt. \% water) }\end{array}$ & 4 & 3 & -0.29 & 1.56 & -0.06 & -3.23 \\
\hline
\end{tabular}


Table E-4. Comparison of intra-replicate ranges for samples analyzed using both Method 1 and Method 2. Relative \% Range $\mathrm{H}_{2} \mathrm{O}$ is the intra-replicate range in wt. \% $\mathrm{H}_{2} \mathrm{O}$ divided by the total average wt. $\% \mathrm{H}_{2} \mathrm{O} * 100$.

\begin{tabular}{|c|c|c|c|c|c|c|c|c|c|}
\hline & $\begin{array}{c}\text { Average } \\
\text { wt. \% } \mathrm{H}_{2} \mathrm{O} \\
\text { Method } 1\end{array}$ & $\begin{array}{c}\text { Average } \\
\text { wt. \% } \mathrm{H}_{2} \mathrm{O} \\
\text { Method } 2\end{array}$ & $\begin{array}{l}\Delta \text { Average } \\
\text { wt.\% } \mathrm{H}_{2} \mathrm{O} \\
(\mathrm{M} 2-\mathrm{M} 1)\end{array}$ & $\begin{array}{l}\text { Range wt. } \\
\% \mathrm{H}_{2} \mathrm{O} \\
\text { Method } 1\end{array}$ & $\begin{array}{l}\text { Range wt. } \\
\% \mathrm{H}_{2} \mathrm{O} \\
\text { Method } 2\end{array}$ & $\begin{array}{c}\Delta \text { Range } \\
\text { wt.\% } \mathrm{H}_{2} \mathrm{O} \\
(\mathrm{M} 2-\mathrm{M} 1)\end{array}$ & $\begin{array}{l}\text { Range } \mathrm{H}_{2} \mathrm{O} \\
\text { relative \% } \\
\text { Method } 1\end{array}$ & $\begin{array}{l}\text { Range } \mathrm{H}_{2} \mathrm{O} \\
\text { relative \% } \\
\text { Method } 2\end{array}$ & $\begin{array}{c}\Delta \text { Range } \mathrm{H}_{2} \mathrm{O} \\
\text { relative \% } \\
\text { (M2-M1) }\end{array}$ \\
\hline Dale & 2.78 & 3.67 & 0.89 & 0.10 & 0.04 & -0.06 & 3.60 & 1.09 & -2.51 \\
\hline Foster Dam & 10.95 & 12.83 & 1.88 & 4.50 & 0.18 & -4.32 & 41.10 & 1.40 & -39.69 \\
\hline Devine & 2.35 & 4.17 & 1.82 & 0.30 & 0.43 & 0.13 & 12.77 & 10.31 & -2.45 \\
\hline Rattlesnake & 3.15 & 2.99 & -0.16 & 0.20 & 0.05 & -0.15 & 6.35 & 1.67 & -4.68 \\
\hline Friend & 2.80 & 3.07 & 0.27 & 0.20 & 0.00 & -0.20 & 7.14 & 0.00 & -7.14 \\
\hline Average: & 4.41 & 5.35 & 0.94 & 1.06 & 0.14 & -0.92 & 24.06 & 2.62 & -21.44 \\
\hline \multicolumn{10}{|l|}{ Average } \\
\hline$\geq 99 \%$ pure: & 2.91 & 3.24 & 0.33 & 0.17 & 0.03 & -0.14 & 5.73 & 0.92 & -4.80 \\
\hline
\end{tabular}


Table E-5. Comparison of intra-replicate ranges for samples analyzed using both Method 1 and Method 2.

\begin{tabular}{|c|c|c|c|}
\hline & $\begin{array}{c}\text { Range } \delta D \\
\text { (\%o) Method } \\
1\end{array}$ & $\begin{array}{c}\text { Range } \delta D \\
\text { (\%o) Method } \\
2\end{array}$ & $\begin{array}{c}\Delta \text { Range } \\
\delta D(\% \text { (\%) }\end{array}$ \\
\hline Dale & 2.9 & 0.2 & -2.7 \\
\hline Foster Dam & 12.3 & 2.3 & -10.0 \\
\hline Devine & 1.7 & 1.4 & -0.3 \\
\hline Rattlesnake & 2.4 & 1.0 & -1.4 \\
\hline Friend & 0.4 & 2.3 & 1.9 \\
\hline Average: & 3.9 & 1.4 & -2.5 \\
\hline $\begin{array}{l}\text { Average } \\
\geq 99 \% \text { pure: }\end{array}$ & 1.8 & 1.2 & -0.7 \\
\hline
\end{tabular}


Table E-6. Sample data for all samples analyzed. $-1 X$ - or $-2 X$ - in the Sample ID indicate the number of times the sample went through heavy liquid separation. Samples with $2 \mathrm{XHF}$ in the name had two rounds of HF treatment. -TM, -TU, and TT indicate location within the tube (middle, upper middle, and top, respectively). Samples at the bottom of the table with a P in the sample ID are pumiceous and were not used in this study.

\begin{tabular}{|c|c|c|c|c|c|}
\hline Method & SampleID & Formation & $\begin{array}{l}\text { Approximate } \\
\text { Age (Ma) }\end{array}$ & $\begin{array}{l}\text { Percent } \\
\text { Water }\end{array}$ & $\begin{array}{c}\text { dD Standard } \\
\text { Corrected (NBS30) }\end{array}$ \\
\hline 1 & CVG013-1 & Dale & 32.7 & 2.7 & -143.9 \\
\hline 1 & CVG013-1dupl & Dale & 32.7 & 2.8 & -146.7 \\
\hline 1 & CVG013-2 & Dale & 32.7 & 2.8 & -146.8 \\
\hline 1 & CVG013-2dupl & Dale & 32.7 & 2.8 & -145.9 \\
\hline 1 & CVG001b-1 & Foster Dam & 26.3 & 8.6 & -114.4 \\
\hline 1 & CVG001b-1dupl & Foster Dam & 26.3 & 9.5 & -115.3 \\
\hline 1 & CVG001b-2 & Foster Dam & 26.3 & 13.1 & -115.7 \\
\hline 1 & CVG001b-2dupl & Foster Dam & 26.3 & 12.6 & -126.7 \\
\hline 1 & CVG020-2 & Devine & 9.7 & 0.8 & -110.0 \\
\hline 1 & CVG020-2dupl & Devine & 9.7 & 0.7 & -110.2 \\
\hline 1 & dc02-09 & Devine & 9.7 & 3.1 & -165.3 \\
\hline 1 & dc02-09dupl & Devine & 9.7 & 3.4 & -163.6 \\
\hline 1 & CVG009 & Devine & 9.7 & 2.4 & -164.9 \\
\hline 1 & CVG009dupl & Devine & 9.7 & 2.4 & -165.5 \\
\hline 1 & CVG019a & Rattlesnake & 7.1 & 3.1 & -138.1 \\
\hline 1 & CVG019adupl & Rattlesnake & 7.1 & 3.3 & -138.2 \\
\hline 1 & CVG019b & Rattlesnake & 7.1 & 3.1 & -135.8 \\
\hline 1 & CVG019bdupl & Rattlesnake & 7.1 & 3.1 & -137.3 \\
\hline 1 & CVG019f & Rattlesnake & 7.1 & 2.6 & -173.5 \\
\hline 1 & CVG019fdupl & Rattlesnake & 7.1 & 2.6 & -173.0 \\
\hline 1 & CVG021 & Rattlesnake & 7.1 & 3.2 & -142.1 \\
\hline 1 & CVG021dupl & Rattlesnake & 7.1 & 3.1 & -142.1 \\
\hline 1 & CVG014 & Friend & 3.7 & 2.9 & -131.3 \\
\hline 1 & $\begin{array}{l}\text { CVG014dupl } \\
\text { CVG013-2X-TT- }\end{array}$ & Friend & 3.7 & 2.7 & -131.7 \\
\hline 2 & $\begin{array}{l}1 \\
\text { CVG013-2X-TT- }\end{array}$ & Dale & 32.7 & 3.7 & -155.3 \\
\hline 2 & 2 & $\begin{array}{l}\text { Dale } \\
\text { Picture }\end{array}$ & 32.7 & 3.7 & -155.6 \\
\hline & CVG036-2X-TT- & Gorge & & & \\
\hline 2 & $\begin{array}{l}3 \\
\text { CVG036-2X-TT- }\end{array}$ & Picture & 26.9 & 1.1 & -115.4 \\
\hline 2 & 4 & Gorge & 26.9 & 1.2 & -110.1 \\
\hline 2 & CVG023-2XHF-1 & Foster Dam & 26.3 & 12.7 & -107.3 \\
\hline
\end{tabular}




\begin{tabular}{|c|c|c|c|c|c|}
\hline 2 & CVG023-2XHF-2 & Foster Dam & 26.3 & 12.9 & -109.6 \\
\hline 2 & CVG035-2XHF-1 & $\begin{array}{l}\text { Mascall } \\
\text { Dreamtime }\end{array}$ & 15.2 & 6.1 & -164.7 \\
\hline 2 & $\begin{array}{l}\text { CVG035-2XHF-2 } \\
\text { CVG034-1X-TM- }\end{array}$ & $\begin{array}{l}\text { Mascall } \\
\text { Dreamtime } \\
\text { Mascall }\end{array}$ & 15.2 & 6.1 & -166.5 \\
\hline 2 & $\begin{array}{l}1 \\
\text { CVG034-1X-TM- }\end{array}$ & $\begin{array}{l}\text { Kangaroo } \\
\text { Mascall }\end{array}$ & 15.2 & 5.4 & -162.8 \\
\hline 2 & 2 & Kangaroo & 15.2 & 5.6 & -163.8 \\
\hline 2 & CVG030-2XHF-1 & Simtustus & 13 & 8.3 & -157.4 \\
\hline 2 & CVG030-2XHF-2 & Simtustus & 13 & 8.0 & -158.8 \\
\hline 2 & CVG040-2X-1 & Devine & 9.7 & 4.4 & -132.8 \\
\hline 2 & CVG040-2X-2 & Devine & 9.7 & 4.0 & -131.5 \\
\hline 2 & CVG038-1 & Rattlesnake & 7.1 & 2.8 & -145.1 \\
\hline 2 & CVG038-2 & Rattlesnake & 7.1 & 2.9 & -146.0 \\
\hline 2 & CVG039-1 & Rattlesnake & 7.1 & 3.0 & -143.2 \\
\hline 2 & $\begin{array}{l}\text { CVG039-2 } \\
\text { CVG028-2X-TM- }\end{array}$ & Rattlesnake & 7.1 & 3.0 & -144.1 \\
\hline 2 & $\begin{array}{l}1 \\
\text { CVG028-2X-TM- }\end{array}$ & Deschutes & 5.8 & 4.6 & -149.7 \\
\hline 2 & $\begin{array}{l}2 \\
\text { CVG027-1X-TM- }\end{array}$ & Deschutes & 5.8 & 4.6 & -148.6 \\
\hline 2 & $\begin{array}{l}1 \\
\text { CVG027-1X-TM- }\end{array}$ & Deschutes & 5.8 & 3.9 & -151.0 \\
\hline 2 & $\begin{array}{l}2 \\
\text { CVG014-2X-TU- }\end{array}$ & Deschutes & 5.8 & 4.0 & -152.6 \\
\hline 2 & $\begin{array}{l}1 \\
\text { CVG014-2X-TU- }\end{array}$ & Friend & 3.7 & 3.1 & -135.2 \\
\hline 2 & $\begin{array}{l}2 \\
\text { CVG029-2X-TM- }\end{array}$ & Friend & 3.7 & 3.1 & -132.9 \\
\hline 2 & $\begin{array}{l}1 \\
\text { CVG029-2X-TM- }\end{array}$ & Quaternary & 0 & 3.3 & -151.9 \\
\hline 2 & $\begin{array}{l}2 \\
\text { CVG013P-1X- }\end{array}$ & Quaternary & 0 & 3.1 & -150.7 \\
\hline 2 & $\begin{array}{l}\text { TT-1 } \\
\text { CVG013P-1X- }\end{array}$ & Dale & 32.7 & 5.23 & -153.53 \\
\hline 2 & $\begin{array}{l}\text { TT-2 } \\
\text { CVG027P-1X- }\end{array}$ & Dale & 32.7 & 4.01 & -152.53 \\
\hline 2 & $\begin{array}{l}\text { TT_1 } \\
\text { CVG027P-1X- }\end{array}$ & Deschutes & 5.8 & 4.18 & -149.26 \\
\hline 2 & $\begin{array}{l}\text { TT_2 } \\
\text { CVG028P-1X- }\end{array}$ & Deschutes & 5.8 & 4.08 & -148.02 \\
\hline 2 & $\begin{array}{l}\text { TT-1 } \\
\text { CVG028P-1X- }\end{array}$ & Deschutes & 5.8 & 5.06 & -143.48 \\
\hline 2 & $\begin{array}{l}\text { TT-2 } \\
\text { CVG029-1X-TT- }\end{array}$ & Deschutes & 5.8 & 5.11 & -142.41 \\
\hline 2 & 1 & Quaternary & 0 & 3.38 & -151.79 \\
\hline
\end{tabular}




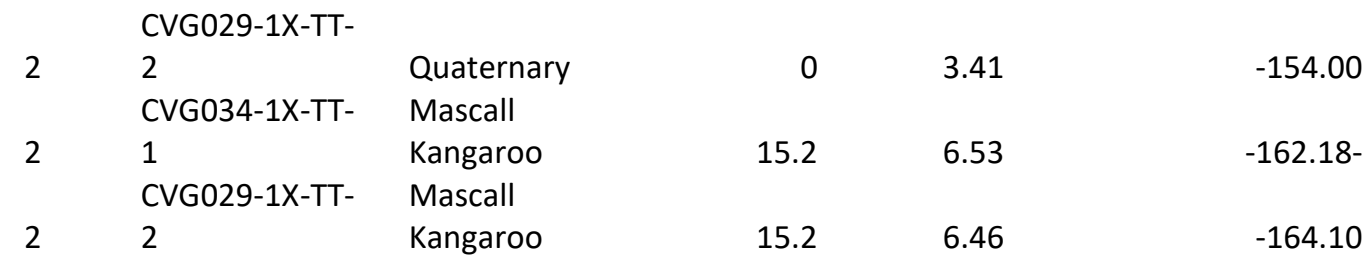


Table E-7. Standard water concentration and deuterium content data

\begin{tabular}{|c|c|c|c|}
\hline Method & Sample ID & $\begin{array}{c}\text { Water Concentration } \\
\text { (wt. \%) }\end{array}$ & $\begin{array}{c}\delta D(\%) \text { Standard } \\
\text { Corrected }\end{array}$ \\
\hline 1 & W62001 & 82.5 & -37.8 \\
\hline 1 & W62001 & 20.3 & -38.2 \\
\hline 1 & Lk.Louise & 99.0 & -145.9 \\
\hline 1 & Lk.Louise & 77.7 & -144.1 \\
\hline 1 & VSMOW & 86.8 & 3.0 \\
\hline 1 & VSMOW & 87.3 & 3.0 \\
\hline 1 & NBS30 & 3.4 & -52.9 \\
\hline 1 & NBS30 & 3.6 & -53.5 \\
\hline 1 & NBS30 & 3.5 & -53.9 \\
\hline 1 & $\begin{array}{l}\text { USGS57 } \\
\text { boiotite }\end{array}$ & 3.8 & -91.3 \\
\hline 1 & $\begin{array}{l}\text { USGS57 } \\
\text { boiotite }\end{array}$ & 3.6 & -90.6 \\
\hline 1 & $\begin{array}{l}\text { USGS57 } \\
\text { boiotite }\end{array}$ & 3.4 & -91.1 \\
\hline 1 & $\begin{array}{l}\text { USGS58 } \\
\text { muscovite }\end{array}$ & 4.1 & -28.1 \\
\hline 1 & $\begin{array}{l}\text { USGS58 } \\
\text { muscovite }\end{array}$ & 4.0 & -27.9 \\
\hline 1 & $\begin{array}{l}\text { USGS58 } \\
\text { muscovite }\end{array}$ & 4.0 & -27.9 \\
\hline 2 & $\begin{array}{l}\text { SN09- } \\
\text { 052RW-1 }\end{array}$ & 4.2 & -148.9 \\
\hline 2 & $\begin{array}{c}\text { SN09- } \\
\text { 052RW-2 }\end{array}$ & 4.2 & -153.0 \\
\hline 2 & $\begin{array}{l}\text { SN09- } \\
\text { 052RW-3 }\end{array}$ & 4.2 & -152.6 \\
\hline 2 & $\begin{array}{c}\text { SN09- } \\
\text { 052RW-4 }\end{array}$ & 4.2 & -156.1 \\
\hline 2 & $\begin{array}{l}\text { SN09- } \\
\text { 052RW-5 }\end{array}$ & 4.2 & -153.4 \\
\hline 2 & $\begin{array}{c}\text { SN09- } \\
\text { 052RW-5 }\end{array}$ & 4.2 & -152.4 \\
\hline 2 & NBS22 & 128.0 & -118.7 \\
\hline
\end{tabular}




\begin{tabular}{rcrr|}
\hline 2 & NBS22 & 118.1 & -123.3 \\
\hline 2 & IAEA-CH7 & 136.1 & -99.4 \\
\hline 2 & IAEA-CH7 & 124.9 & -98.4 \\
\hline 2 & IAEA-C3 & 60.7 & -38.7 \\
\hline 2 & IAEA-C3 & 55.3 & -33.0 \\
\hline 2 & NBS-30 & 3.6 & -46.6 \\
\hline 2 & NBS-30 & 3.7 & -45.6 \\
\hline 2 & NBS-30 & 3.6 & -48.6 \\
\hline
\end{tabular}


Table E-8. Standard deviations for standards

\begin{tabular}{|c|c|c|c|}
\hline Method & Standard & $\begin{array}{c}\text { verage } \delta D \\
(\%)\end{array}$ & $1 \sigma(\%)$ \\
\hline 1 & W62001 & -38.0 & 0.2 \\
\hline 1 & Lk.Louise & -145.0 & 0.9 \\
\hline 1 & VSMOW & 3.0 & 0.0 \\
\hline 1 & NBS30 & -53.4 & 0.4 \\
\hline 1 & $\begin{array}{l}\text { USGS57 } \\
\text { boiotite }\end{array}$ & -91.0 & 0.3 \\
\hline 1 & $\begin{array}{l}\text { USGS58 } \\
\text { muscovite }\end{array}$ & -28.0 & 0.1 \\
\hline 2 & $\begin{array}{l}\text { SN09- } \\
\text { 052RW }\end{array}$ & -152.7 & 2.1 \\
\hline 2 & NBS22 & -121.0 & 2.3 \\
\hline 2 & IAEA-CH7 & -98.9 & 0.5 \\
\hline 2 & IAEA-C3 & -35.9 & 2.9 \\
\hline 2 & NBS-30 & -46.9 & 1.2 \\
\hline
\end{tabular}




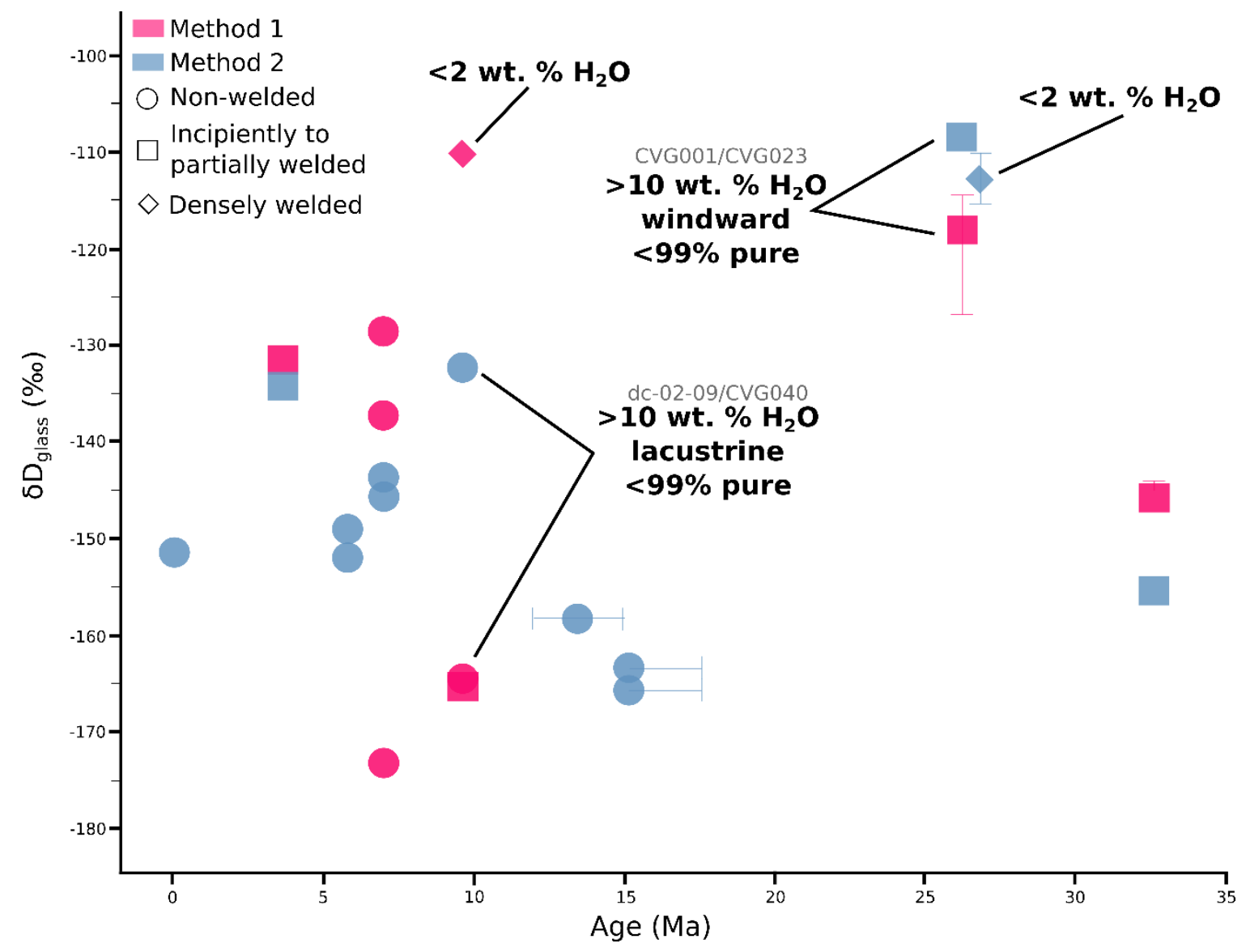

Figure E-9. $\delta D$ values of all analyzed volcanic glass samples colored by preparation method (Red is Method 1 , Blue is Method 2). Generalized textures are indicated by shapes (circle is non-welded, square is incipiently to partially welded and diamond is densely welded). Vertical error bars are intra-replicate range (2-6 replicates per point). Horizontal (age) error bars are based on $\pm 2 \sigma$ for radiometric dates and stratigraphic context for undated units. 


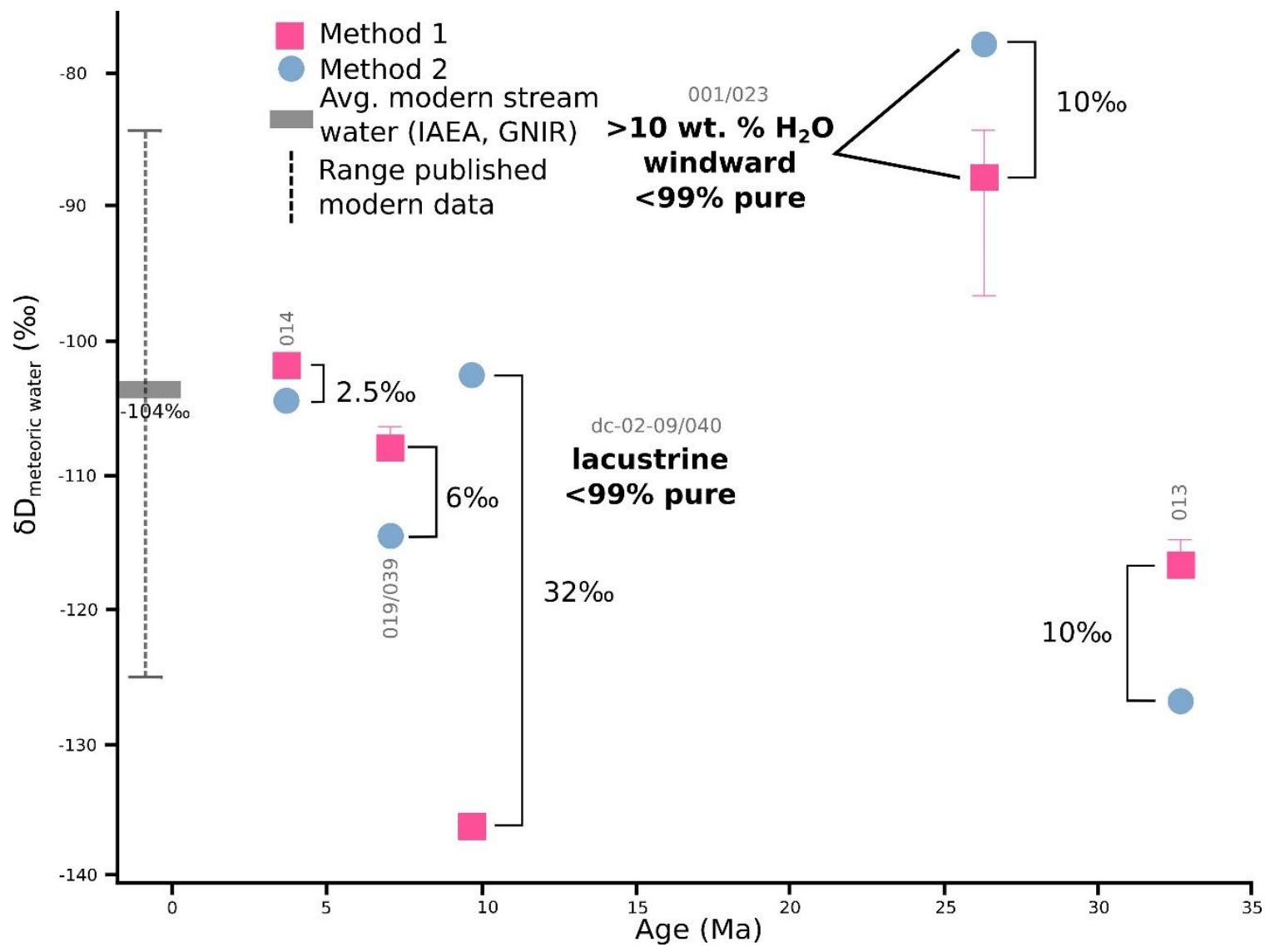

Figure E-10. $\delta \mathrm{D}(\% \circ)$ vs. Age (Ma) for samples prepared using both methods. Corrected with original fractionation factor (Friedman, Gleason, Sheppard, et al., 1993). 


\section{F - Opportunities for Additional Research}

\section{Age Dating Collected Samples}

Age dating of collected samples will greatly increase the resolution and decrease the uncertainty of this paleoclimate proxy data, especially within formations containing multiple ash beds. It will also increase the number of possible sample localities, as there would be less reliance on literature for tuff unit correlation and age dates.

\section{Sampling a Widespread Ash Layer in Many Locations}

Isotopic composition of volcanic glass may be spatially heterogeneous (Nolan and Bindeman, 2013; Cassel and Breecker, 2017, this study). Sampling the same ash unit (or at least ashes of similar age and composition) across a large geographic extent and different depositional environments will help to understand anomalous values and the extent of geographic and textural variability. Widespread ignimbrite sheets such as the Rattlesnake Tuff (Streck and Grunder, 1995) could be sampled across much of eastern Oregon. Sampling from the precursory fallout and nonwelded basal ignimbrite sections in various localities is of interest to determine if the isotopic compositions of similar-aged but chemically distinct glass is relatively constant. A field trip guide by Streck and Ferns (2004) notes several localities where these different textures are located.

The windward side of the Cascade Range is poorly mapped and sampled compared to eastern Oregon. Correlated ash $\delta \mathrm{D}$ values from either side of the arc such as in the Deschutes Formation (Conrey et al., 2002; Pitcher et al., 2017), could be compared to modern isotopic shifts over the same area. Comparing $\delta \mathrm{D}_{\text {gass }}$ values of geochemically and texturally similar glass across the range could also be used to attempt environmental reconstructions. This would potentially have less

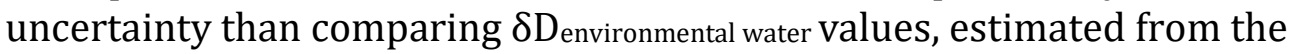
fractionation equation, to modern waters.

\section{Collecting various textures within a unit}

Collecting various textures within a unit can help us discern how much isotopic variability there is within the unit itself. This variability could be due to texture, amount of hydration, compositional differences, different hydration water, or differing amount of contamination.

A numerical model by Keating (2005) suggests that during cooling of an ignimbrite, welding near the center may act as a low-permeability barrier to vapors in the basal section of the flow. This would cause vapors to recirculate instead of escaping through the top of the flow, devitrifying the lower unit. Above the heavily welded zone, another devitrification horizon due to the infiltration of meteoric water may be present. Stratigraphic columns that exhibit textural changes from high permeability (non-welded) at the top, low permeability (densely welded or devitrified) in the middle and high permeability (non-welded) at the base are of specific interest, to determine if different source waters can preferentially hydrate certain areas on either side of a low-permeability zone and leave distinct isotopic signatures. This could also help determine if there is significant hydration at 
elevated temperature during the cooling of an ignimbrite sheet, and what impacts this may have on measured $\delta \mathrm{D}$ values. This type of outcrop can be difficult to find, as non-welded zones near the top of a unit are less likely to be preserved than those at the base of a unit, which are protected by the indurated to welded zones above. Streck and Grunder (1995), note locations where the non-welded bases of multiple flows within the Rattlesnake Tuff exist in a single outcrop, as well as possible localities with incipiently welded sections near the top of the cooling unit.

\section{Collecting Modern Water Samples for Comparison}

A reliance on published data for modern water comparison can be difficult, especially for rural areas in eastern Oregon. It can be difficult to collect modern precipitation samples in an arid locality like the high desert of eastern Oregon, and there are no GNIP sites measuring precipitation (IAEA). However, even stream samples taken multiple kilometers from a glass locality could increase the accuracy and confidence of local water values, especially in sparsely sampled areas east of $\sim 120^{\circ}$ longitude. Soil water samples are also a possible option for modern water comparison (Stauffer and Cassel, 2017).

\section{Estimating Magmatic Water Contributions}

The use of step-heating analyses (e.g. Martin et al., 2017) and/or magmatic degassing models (Seligman et al., 2016) can help determine and correct for the contribution of magmatic water to the overall measured isotopic composition. Densely welded samples are typically avoided, as they can be very difficult to hand crush and are not usually hydrated by meteoric waters. However, collecting, preparing, and analyzing these samples could also aid in estimating the amount and composition of magmatic waters (Martin et al., 2017; Seligman et al., 2016). 